Joice Genaro Gomes

\title{
Os Programas de Melhorias Habitacionais: \\ Elementos a serem considerados para uma proposta de assistência técnica continuada a partir das experiências do Brasil e de Cuba
}

Dissertação apresentada a Faculdade de Arquitetura e Urbanismo da Universidade de São Paulo para obtenção do título de Mestre em Arquitetura e Urbanismo

Área de Concentração: Habitat

Orientador: Prof. Dr. Antônio Cláudio Moreira Lima e Moreira 
AUTORIZO A REPRODUÇÃO E DIVULGAÇÃO TOTAL OU PARCIAL DESTE TRABALHO, POR QUALQUER MEIO CONVENCIONAL OU ELETROONICO, PARA FINS DE ESTUDO E PESQUISA, DESDE QUE CITADA A FONTE.

E-MAIL DA AUTORA: joigenaro@gmail.com Gomes, Joice Genaro
G633p os programas de melhorias habitacionais: elementos a
serem considerados para uma proposta de assistência técnica continuada a partir das experiências do Brasil e de Cuba / Joice Genaro Gomes. -- São Paulo, 2014.

113 p. : il.

Dissertação (Mestrado - Ȧrea de Concentração: Habitat) FAUUSP.

Orientador: Antônio Cláudio Moreira Lima e Moreira

1. Habitação popular 2.Politica habitacional 3.Autoconstrução I.Título

CDU 711.58 
Joice Genaro Gomes

\section{Os Programas de Melhorias Habitacionais: \\ Elementos a serem considerados para uma proposta de assistência técnica continuada a partir das experiências do Brasil e de Cuba}

Dissertação apresentada a Faculdade de Arquitetura e Urbanismo da Universidade de São Paulo para obtenção do título de Mestre em Arquitetura e Urbanismo

Área de Concentração: Habitat

Banca Examinadora: 
Aos Arquitetos da Comunidade de Cuba, pela perseverança. 


\section{Agradecimentos}

Agradeço ao professor Antônio Cláudio pela orientação.

Agradeço aos amigos da Prefeitura de São Bernardo do Campo que tanto me apoiaram nos momentos mais difíceis que passei ao longo da construção dessa pesquisa. São eles: Danilo, Roseli, Paula, Jackeline, Lilian, Ida, Luciano, Conceição, Roseane, Cláudia, Lara, Cecília, Paulinho, Paulão, Maurício e Wagner.

Agradeço a minha amiga Daniela com quem dividi as angústias e as alegrias da construção de um programa de assistência técnica à população de baixa renda na cidade de Campinas.

Agradeço a Prefeitura Municipal de Diadema pelas informações prestadas sem as quais essa pesquisa não seria possível.

Aos amigos que fiz em Holguín e que guardo nas minhas melhores lembranças. São eles: Ricardo, Danis, Yaqueline, Laritza e Vivian. Agradeço pelos materiais cedidos, pelo acolhimento e pela paciência em me explicar todos os detalhes do trabalho desenvolvido em Cuba. A eles toda a minha gratidão.

Agradeço ao Júlio pela elaboração dos mapas, mas, principalmente pelo amor e tranquilidade que me transmitiu na reta final dessa jornada.

Agradeço ao meu cunhado e amigo Rodolfo, pelas sugestões e conversas sempre tão enriquecedoras que tanto contribuíram para o desenvolvimento dessa pesquisa.

Agradeço a Geisa, minha querida irmã, que com paciência e amor dedicou seu tempo à leitura atenta ao texto.

Agradeço ao meu sobrinho, Antônio, que alegrou os dias mais difíceis.

Agradeço ao Jeferson, meu querido irmão, pelo incentivo e pelo apoio.

Agradeço a Antonio Roberto, meu pai, pelo amor incondicional e que do seu jeito me ajudou a seguir em frente.

E, finalmente, agradeço a minha amada mãe, Maria Alba, por toda a dedicação e incentivo e que tanta falta me faz. 


\section{Resumo}

A presente pesquisa foca os programas de assistência técnica direcionada às melhorias habitacionais ofertados à população de baixa renda no Brasil, mais precisamente na cidade de Diadema, e em Cuba, na província de Holguín. $O$ conceito de melhorias habitacionais presente nesse estudo abrange todas as intervenções realizadas em moradias existentes que visam à melhoria da condição de habitabilidade do espaço construído como a ampliação da área construída; a melhoria das condições de iluminação e de ventilação; a melhoria das instalações hidrossanitárias; a correção de patologias construtivas; entre outros. Dada a complexidade da questão e o universo da sua atuação, a pesquisa visa discorrer sobre a efetividade dos programas de assistência técnica de melhorias habitacionais voltados à população de baixa renda ao considerar o projeto personalizado, a escala de atuação alcançada e a relação do arquiteto com a população. Para tanto, foram avaliados dois programas governamentais, sendo eles: a segunda fase do Programa "Tá Bonito" da prefeitura de Diadema, município da Região Metropolitana de São Paulo, realizado no núcleo Vila Olinda, durante os anos de 2006 a 2008; e o Programa Arquitetos da Comunidade desenvolvido em Cuba desde 1994 com foco na atuação dos profissionais da província de Holguín. A partir das dificuldades enfrentadas pelos programas e das conquistas alcançadas pelos mesmos, analisaremos as duas propostas a partir de quatro aspectos ora apresentados: 1) as formas de divulgação dos programas e o acesso aos serviços; 2) a aproximação do arquiteto com a população; 3) a elaboração dos projetos personalizados e 4) os resultados e as limitações; a fim de vislumbrar elementos importantes que contribuam para a construção, pelos governos municipais, de uma metodologia de assistência técnica de melhorias habitacionais voltada ao atendimento da população de baixa renda.

Palavras-chave: habitação popular; política habitacional; autoconstrução 


\begin{abstract}
This research focus on the technical assistance programs for home improvements directed to lowincome dwellers in Brazil, more precisely in the Brazilian city of Diadema and in the province of Holguín, in Cuba. The concept of home improvement herein adopted encompasses all building interventions carried out in existent dwellings aimed to improve the indoor living conditions such as the increase of the built area; the improvement of lighting and ventilation conditions; the improvement of the hydrosanitary installations; the correction of building pathologies; among others. Given these issues' complexity and the broadness of their action, this research aims to discuss the effectiveness of such programs considering customized project design, scale and the relationship between architect and dwellers. For such, two governmental programs were assessed: the second phase of the Program "Tá bonito" (It is Beautiful) from the municipal government of Diadema, State of São Paulo (Brazil), carried out in the settlement of Vila Olinda from 2006 to 2008; and the Program Architects of the Community developed in Cuba since 1994 with a focus on the work of the professionals of Holguín province. From the difficulties faced by these programs and their achievements, the two programs are assessed in the following four aspects: 1) the ways of publicizing the programs and the access to their services; 2) the approximation of the architect with the dwellers; 3 ) the custom-made project designs; and 4) their results and limitations in order to identify important elements to contribute to the elaboration of a technical assistance methodology for home improvements directed to low-income dwellers by municipal governments.
\end{abstract}

Keywords: low-income housing; housing policy; self-construction 
Índice

Introdução

1. A autoprodução da moradia no Brasil ................................................... 18

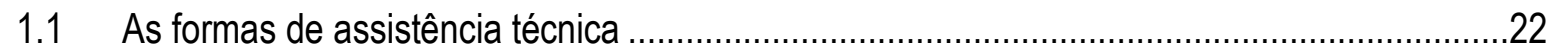

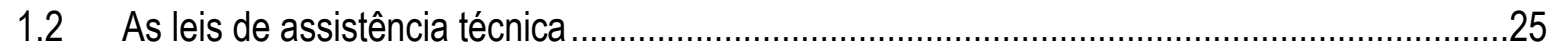

1.3 Algumas experiências de assistência técnica de melhorias habitacionais ..............................28

2. 0 caso do Brasil - O Programa Tá Bonito ..................................................... 33

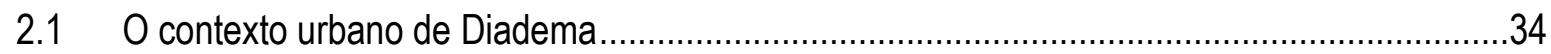

2.2 A urbanização de favelas .................................................................................................

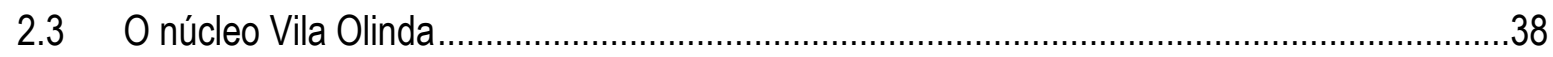

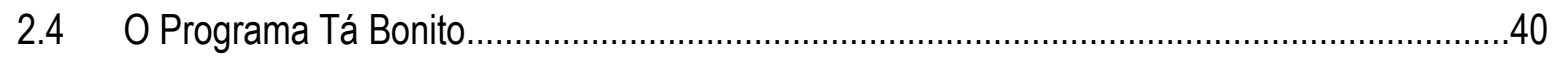

2.5 A escolha da comunidade $e$ as fases do programa...........................................................41

$2.6 \quad$ Os procedimentos iniciais................................................................................................. 
2.7 Assistência técnica: a elaboração dos projetos, os técnicos e os moradores.

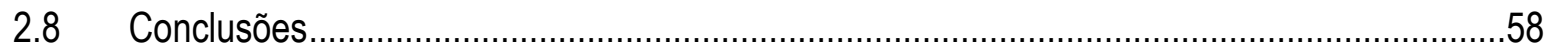

3. $\mathrm{O}$ caso de Cuba - Os Arquitetos da Comunidade …........................................63

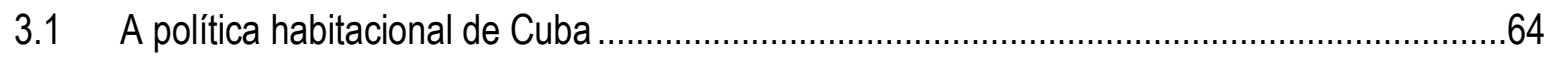

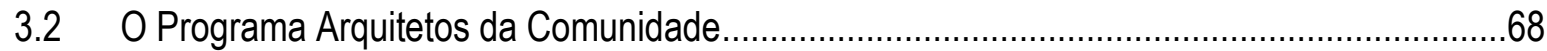

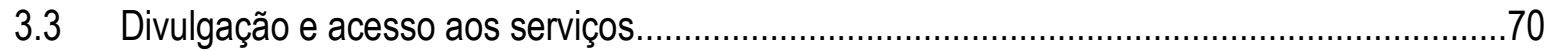

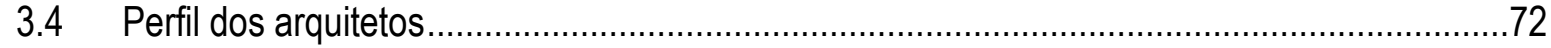

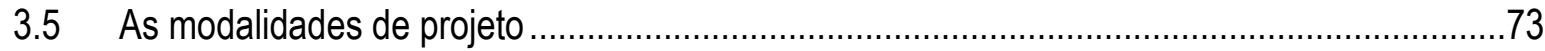

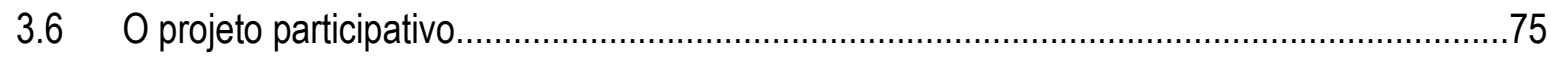

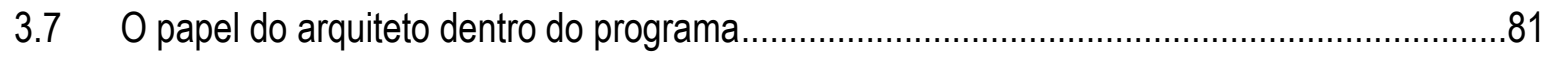

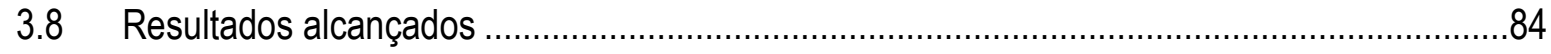

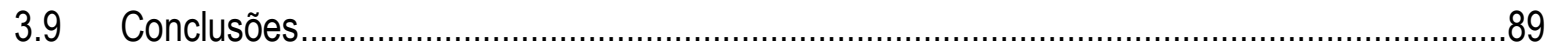

4. Elementos para uma proposta de assistência técnica.....................................92

4.1 As estratégias de divulgação dos programas e 0 acesso aos serviços .................................93

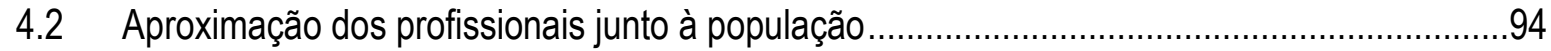

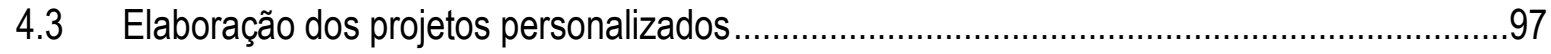

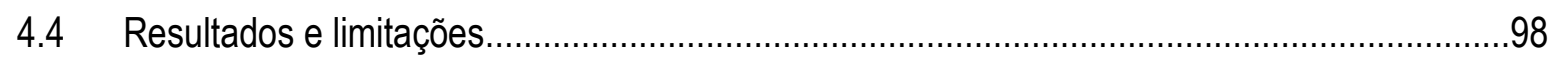

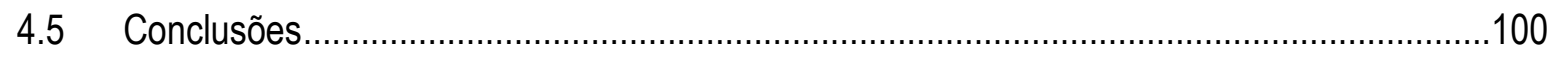

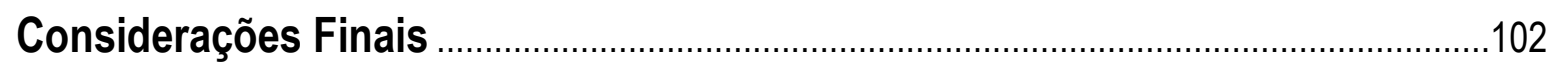

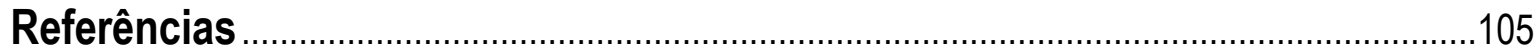




\section{Lista de Imagens}

Figura 1.Imagem dos manuais publicados pela ABCP direcionados ao autoconstrutor .24

Figura 2. Espacialização das três fases do Programa Tá Bonito no núcleo Vila Olinda .43

Figura 3. Exemplo dos desenhos elaborados com as intervenções propostas e apresentados às famílias.

Figura 4. Espacialização das unidades atendidas durante a segunda fase do Programa Tá Bonito onde atualmente é possível identificar intervenções .58

Figura 5. Travessa Salvador. Imagens das casas em três momentos. .59

Figura 6. Propaganda que divulgava a reforma urbana, um dos ícones do governo de Fidel Castro.....65 Figura 7. Exemplo de conjunto habitacional executado pelo Estado com elementos pré-fabricados.....66

Figura 8. Número de profissionais distribuídos por província.. 69

Figura 9. Vista da entrada de um dos escritórios dos Arquitetos da Comunidade. .71

Figura 10. Imagem de uma das casas visitadas localizada ao norte da cidade de Holguín . .74

Figura 11. Necessidade de construção do muro de divisa motivou a visita do especialista.. .74 
Figura 12. Moradia localizada na Rua Arias: plantas da situação existente durante o levantamento e projeto de melhoria proposto. Fotos da fachada antes e depois das intervenções.

Figura 13. Plantas baixas da casa da Rua Agramonte da situação existente antes da intervenção e da proposta escolhida pelos moradores. Fotos da fachada de antes da intervenção e depois

Figura 14. Moradia localizada na Rua Prado: plantas da situação existente durante o levantamento e projeto de melhoria proposto. Fotos da fachada de antes e depois das intervenções.

Figura 15. Número de atendimentos realizados por ano entre 1994 e 2012.

Figura 16. Número de atendimentos por modalidade de serviço contratado entre os anos de $2008 \mathrm{e}$ 2012.

Figura 17. Distribuição dos atendimentos realizados dentro da modalidade "Projeto" entre os anos de 2008 e 2012 .88

Figura 18. Distribuição dos atendimentos realizados dentro da modalidade 'Autorização para Construção' entre os anos de 2008 e 2012. .89

\section{Lista de Tabelas}

Tabela 1. Dificuldades e conquistas do Programa Tá Bonito. 60

Tabela 2. Dificuldades e conquistas do Programa Arquitetos da Comunidade .89

Tabela 3. Estratégias de divulgação e forma de acesso aos serviços. .93

Tabela 4. Aproximação do profissional junto à população. .95

Tabela 5. Elaboração dos projetos personalizados. .97

Tabela 6. Resultados e limitações dos programas. .99 


\section{Introdução}

O meu olhar sobre as questões habitacionais do país foi iniciado ainda na Faculdade de Arquitetura e Urbanismo da PUC Campinas dentro do Programa de Iniciação Científica que buscou discutir as "casas de frente e fundo" construídas no município. Após a conclusão do curso, ingressei na Companhia de Habitação Popular de Campinas - Cohab Campinas - e passei a integrar a equipe responsável pelo desenvolvimento dos projetos de urbanização de favelas que culminariam na regularização fundiária.

Nesse momento, com mais de 150 favelas e ocupações1 e após quase dez anos sem a entrega de títulos, o município campineiro retomava o programa de regularização fundiária e urbanização de favelas com o objetivo de conceder o título de posse às famílias moradoras de núcleos bastante precários da cidade. Fazia parte do escopo do meu trabalho realizar levantamentos de campo e diagnósticos técnicos para, posteriormente, executar os projetos de arruamento contemplando os equipamentos públicos e a infraestrutura necessários. Os desenhos deveriam resultar na consolidação da maior quantidade possível de moradias existentes, premissa intrínseca aos projetos de urbanização de favelas no Brasil.

Construídos com materiais permanentes, esses abrigos cobertos por lajes ou telhas de fibrocimento que, mesmo se alternando, formavam um aparente monólito cinza quando observados pelas imagens dos levantamentos aerofotogramétricos. 0 adensamento das construções impedia, em muitos casos, a determinação dos perímetros dos lotes cuja descrição seria necessária para a individualização dos títulos de posse, sendo o levantamento de campo imprescindível para sanar as dúvidas de divisas.

\footnotetext{
${ }^{1}$ Segundo Cano (2002, p. 126), "A partir de 1990, com a proibição da regularização de moradias em áreas públicas pela Lei Orgânica do Município, a ocupação de terra pública ou privada para moradia passou a ser designada por ocupação e não mais por favela."
} 
Durante 0 ano que trabalhei no programa, conheci mais de 15 favelas e diversas casas dos moradores desses núcleos que, invariavelmente, nos convidavam para entrar e tomar um café e assim, segundo eles, ter o prazer da "visita" de um arquiteto. A precariedade dessas casas não era evidente para quem olhava de fora, sendo esse o único olhar que deveria ser observado no levantamento de campo. Somado ao afastamento insuficiente entre as construções já verificado nas imagens aéreas e por trás das paredes em alvenaria sem reboco, presenciava-se a ausência de iluminação natural, ventilação precária, umidade e fiação elétrica aparente. Ao entrar nos lotes era comum tropeçarmos nas tubulações de água e esgoto expostas. Falta de privacidade e doenças respiratórias eram frequentes nas falas dos moradores ao mesmo tempo em que relatavam as dificuldades para a construção da casa.

Mesmo diante destas precariedades, as construções eram apontadas e classificadas no projeto de urbanização como "unidades a serem consolidadas" e não se discutiam as demais melhorias necessárias para oferecer à população condições mínimas de conforto e segurança do espaço interno das moradias. Excetuando-se as casas que seriam removidas pelos riscos de desmoronamento ou de inundação, que seriam substituídas por novas construções, as únicas moradias a sofrerem interferências seriam aquelas cuja parte da construção fosse atingida pelas obras. Para mim, tornavase evidente a necessidade da aproximação do arquiteto junto à população moradora dessas casas precárias como auxílio para a transformação do espaço habitado.

A partir desta minha experiência profissional na Cohab, no ano de 2006 conheci, por meio do Prof. Dr. Ricardo Moretti, o programa uruguaio de assistência técnica de iniciativa da Sociedade de Arquitetos do Uruguai, cuja proposta era tornar o serviço de arquitetura mais próximo da população. Tendo como norte a experiência do programa uruguaio, neste mesmo ano, em parceria com uma amiga arquiteta, fundamos um escritório que tinha como missão oferecer à população de baixa renda de Campinas assistência técnica em arquitetura diretamente nas comunidades pobres e com baixo custo. O pagamento pelos serviços prestados provinha parte dos recursos próprios das famílias e parte subsidiada por doações provenientes de ONG e grupo de empresários.

A cada assistência prestada nas comunidades, questionava-me como seria possível manter um atendimento individual e personalizado e ao mesmo tempo galgar escala em quantidade de atendimento, ou melhor, como atender o maior número possível de moradias sem perder a especificidade de cada projeto? 
Foi então que em 2010 participei do Primeiro Encontro de Arquitetos Latino-Americanos realizado na cidade de Montevidéu. Nesse encontro, com a participação de representantes de sete países da América Latina2, buscou-se compartilhar as experiências em programas de assistência técnica em arquitetura ofertada de forma individualizada. Foi neste espaço que conheci a experiência de Cuba e me debrucei em compreender o funcionamento do programa daquele país que foi 0 precursor de outras experiências da América Latina, inclusive a uruguaia.

Em 2012 realizei uma visita a Cuba como parte da minha pesquisa e tive a oportunidade de conhecer de perto os profissionais envolvidos e o sistema de atendimento do Programa Arquitetos da Comunidade.

\section{A pesquisa}

A presente pesquisa foca os programas de assistência técnica direcionada às melhorias habitacionais ofertados à população de baixa renda no Brasil, na cidade de Diadema e em Cuba, na cidade de Holguín.

No Brasil, segundo contagem dos arquitetos inscritos no CAU - Conselho de Arquitetura e Urbanismo (CAU, 2013) e dos dados populacionais divulgados pelo último Censo (IBGE, 2010), existia aproximadamente um arquiteto para cada 2.000 habitantes. Essa proporção não se distancia daquela verificada em alguns países europeus, como a França, que possui um arquiteto para cada 2.420 habitantes ou Grã-Bretanha com um arquiteto para cada 2.043 habitantes (MARAGNO, 2012).

Ao nos depararmos com as paisagens constituídas pelas casas autoconstruídas nas favelas e nos loteamentos, sobretudo das periferias das grandes e das médias cidades do país, torna-se evidente que a grande maioria dessas moradias nunca teve acesso aos serviços dos quase 106 mil arquitetos ativos no país 3 .

Bonduki e Rolnik (1982), Lima (1980), Lemos e Sampaio (1993) entre outros, se propuseram a descrever o processo de autoconstrução nos loteamentos periféricos de São Paulo e do Rio de Janeiro ao final dos anos de 1970 e apontaram para as deficiências e riscos que as construções sem qualquer

\footnotetext{
${ }^{2}$ Em 2010 estavam representados Argentina, Chile, Cuba, Equador, Peru, Uruguai e Venezuela.

${ }^{3}$ Em 14 de agosto de 2013, o CAU registrou 106.038 arquitetos e urbanistas ativos no país - aqueles que já tiveram algum tipo de interação com o SICCAU Corporativo, através de emissão de certidão, RRT ou qualquer outro serviço que 0 sistema presta à sua comunidade.
} 
assistência técnica geram aos usuários e aos autoconstrutores; como problemas de habitabilidade decorrentes da realização da obra sem planejamento e em etapas descontínuas, desperdício de recursos, entre outros.

Nesses pedaços de cidade, onde a infraestrutura chegou, assim como seus moradores, sem qualquer planejamento, presenciamos quão dinâmica é a construção nas constantes "melhorias" e nas expansões dessas moradias; seja pelo seu alto valor de uso, gerado pela necessidade de garantir maior conforto aos seus moradores ou mesmo a urgência de abrigar algum familiar; seja pelo seu valor de troca, determinado pela necessidade de renda adicional com o aluguel de cômodos ou mesmo por uma futura comercialização da moradia.

A necessidade da formulação de programas de assistência técnica de melhorias habitacionais ocorre dentro de um contexto onde a modalidade da autoconstrução, iniciada durante a crise habitacional nos anos de 1940 (BONDUKI, 2002; MAUTNER, 2010; MARICATO, 1997) somente foi entendida como uma alternativa habitacional a partir da década de 1980 (BONDUKI, 2000).

Impossibilitados de acessar o mercado formal de habitação, é na informalidade, tanto fundiária, ocupando áreas públicas e privadas ou mesmo adquirindo terrenos em loteamentos irregulares e clandestinos; quanto da construção, não seguindo qualquer tipo de norma edilícia e de regras de ocupação do solo, que a população encontra a resposta para satisfazer a necessidade do abrigo.

A presente pesquisa parte do princípio de que a aproximação do arquiteto junto às famílias que, diante da necessidade, autopromovem a construção de suas moradias é fundamental para contribuir na garantia da qualidade do espaço habitado. E, dessa maneira, devem ser viabilizados programas pelos municípios de maneira continuada que promovam o acesso facilitado ao serviço de assistência técnica.

O serviço de assistência técnica para a população de baixa renda somente foi assegurado no final de 2008 com a promulgação da Lei $n^{0} 11.888$, de 24 de dezembro de 2008. Ela garante às famílias com renda de até três salários mínimos assistência técnica pública e gratuita para o projeto e a construção da moradia; e aponta a possibilidade de estruturação de programas no âmbito municipal que reconheçam no atendimento personalizado uma maneira de responder às necessidades dessa demanda reprimida de estimular a construção assistida.

Contudo, a trajetória da assistência técnica teve início junto aos movimentos de moradia, no início dos anos de 1980, reivindicando a autogestão dos mutirões na produção de suas moradias. 0 
resultado dessa luta influenciou as políticas habitacionais das três esferas de governo que bem ou mal passaram a considerar essa modalidade, os mutirões autogeridos, dentro dos seus programas de produção de novas moradias, tornando-se também uma alternativa profissional aos arquitetos.

Em 2006, o primeiro Seminário Nacional de Assistência Técnica, organizado pelas entidades de classe dos arquitetos em parceria com a Caixa Econômica Federal e o Ministério das Cidades, tinha como objetivo a construção do texto do projeto de lei que instituiria nacionalmente o serviço de assistência técnica como obrigatório à população de baixa renda. Para tanto, foram apresentadas nesse encontro diferentes experiências de assistência técnica que abrangeram a produção de novas moradias, urbanização de favelas, regularização fundiária e melhorias habitacionais nas áreas urbanas e rurais do país, realizadas por diferentes agentes entre eles as entidades de classe, universidades, poder público e ONGs. Posteriormente a esse encontro, foi lançada uma publicação na qual foram compiladas 90 iniciativas representativas das experiências brasileiras (ARRUDA; CUNHA; MEDEIROS, 2007).

Apesar de serem expressivas, essas ações ocorreram de maneira isolada e pontual e, em muitos casos, não passaram de "projetos-piloto", sem conquistarem uma escala de atuação compatível com a urgência do problema. Do total de experiências apresentadas na publicação, em apenas oito foram relatadas propostas de assistência técnica de melhorias habitacionais.

A aprovação da lei federal em 2008 avançou no sentido de reconhecer e tornar obrigatória a prestação dos serviços de forma continuada pelos estados e municípios sendo financiada com recursos da União. Contudo, decorridos quase cinco anos de sua promulgação, e apesar dos constantes debates acerca do tema pelas entidades de classe, conselhos de profissionais, associações de ensino, órgãos públicos, movimentos de moradia, Caixa Econômica Federal (CEF) e Ministério das Cidades, não se avançou na efetivação da assistência técnica como um direito.

Dada a complexidade da questão e o universo da sua atuação, a presente pesquisa visa discorrer sobre a efetividade dos programas de assistência técnica de melhorias habitacionais à população de baixa renda considerando o projeto personalizado e a escala de atuação alcançadas. Para tanto, foram avaliados dois programas governamentais, sendo eles: a segunda fase do Programa "Tá Bonito", iniciativa da prefeitura de Diadema, município da Região Metropolitana de São Paulo, durante os anos de 2006 a 2008; e o Programa Arquitetos da Comunidade desenvolvido em Cuba, desde 1994 até os dias atuais. 
Essa dissertação está divida em quatro capítulos. O primeiro capítulo focará o processo de autopromoção da moradia, sempre marginal às políticas públicas, cujo entendimento é primordial para compreendermos o espaço que a temática da assistência técnica conquistou dentro do contexto de produção estatal da habitação; que continua a excluir os pobres do direito à cidade e à moradia de qualidade.

No segundo capítulo, analisaremos o programa de assistência técnica de melhorias habitacionais executado no núcleo Vila Olinda, na cidade de Diadema - SP. A escolha desse objeto de estudo se deu pelo contexto em que foi criado: a retomada dos programas de urbanização e de regularização fundiária de favelas, iniciados no começo dos anos de 1980. Ainda que tenha tido um caráter piloto, a assistência técnica foi utilizada de forma individualizada na melhoria interna de 45 moradias.

No terceiro capítulo, discutiremos a experiência dos Arquitetos da Comunidade, em Cuba, e os alcances e as limitações do programa ao considerarmos o histórico político e econômico do país. 0 programa foi incorporado, em 1998, ao Instituto Nacional de Habitação, e está atualmente representado em todos os municípios do país com mais de dez mil moradores na área urbana. Debruçar-nos-emos, mais precisamente, a análise do desenvolvimento do programa na Província de Holguín, que até o final de 2012, tinha realizado mais de 185 mil atendimentos.

No quarto capítulo, a partir das experiências estudadas, apontaremos os elementos importantes que julgamos serem relevantes para a elaboração de um programa de assistência técnica de melhorias habitacionais, pelos governos municipais, voltado ao atendimento da população de baixa renda, ao considerarmos: 1) as estratégias de divulgação dos programas e a forma de acesso aos serviços; 2) a aproximação do arquiteto com a população; 3) a elaboração dos projetos personalizados e 4) os resultados e limitações.

Finalmente, nas Considerações Finais concluiremos o presente trabalho, cientes que esta pesquisa é um recorte do tema e que a discussão é passível de outros olhares. 


\section{A autoprodução da moradia no Brasil}

A produção doméstica da moradia no Brasil4, a partir da segunda guerra mundial, foi proporcionada pela industrialização dos materiais básicos de construção e pela criação de um sistema baseado no transporte rodoviário, os quais possibilitaram que o trinômio loteamento popular/ casa própria/ autoconstrução se tornasse a forma predominante de produção habitacional da classe trabalhadora (MAUTNER, 2010).

Para uma enorme massa de trabalhadores saídos do campo para trabalhar nas grandes cidades do país, cujos salários recebidos não comportavam as despesas com o aluguel da moradia, a autoconstrução baseada na associação e cooperação entre pessoas para a construção da casa própria tornou-se a única arquitetura possível (MARICATO, 1982).

Até as duas primeiras décadas do século $X X, 0$ aluguel, de cômodos em cortiços para os operários com menores salários, e as casas em vilas, para os operários melhor remunerados, era a forma como os trabalhadores acessavam a moradia ${ }^{5}$ (BONDUKI, 1983). Com o a crise econômica pós-

\footnotetext{
${ }^{4}$ Bonduki (1992) caracterizou a produção doméstica da moradia como a apropriação do trabalhador de todas as etapas da construção da casa, decidindo o projeto, programando as etapas da construção de acordo com a disponibilidade de recursos materiais e humanos, a escolha do material, contratando mão de obra especializada ou utilizando sua própria mão de obra.

${ }^{5}$ Em São Paulo, por exemplo, a busca por melhores oportunidades de trabalho na indústria e no comércio acelerou o crescimento populacional. Entre 1872 e 1893, o aumento do número de moradores passou de cerca de 23 mil habitantes para, aproximadamente, 130 mil e chegou ao ano de 1900 com 240 mil moradores; crescimento este que originou a primeira crise habitacional (BONDUKI, 2002). Novos bairros foram implantados de forma precária para abrigar a população que chegava à cidade em busca de trabalho. 0 crescimento urbano acelerado desarticulado de uma política de provisão de infraestrutura de saneamento básico decorreu na disseminação de epidemias (BONDUKI, 2002). Rolnik (1982) aponta para o início de uma segregação social que se refletiu nas diferentes formas de apropriação do espaço urbano. Enquanto a elite da época concentrava-se em bairros homogêneos cujo padrão de habitação era o palacete isolado no lote; os bairros populares concentravam a moradia dos trabalhadores, em suas diversas modalidades, sendo os cortiços o lugar dos "grupos mais miseráveis da cidade" (ROLNIK, 1982, p. 116). Caracterizados pela alta densidade de moradias e moradores, os cortiços eram vistos como foco de epidemias e de imoralidades. Bonduki (2002, p. 33) aponta que o início da intervenção do governo "no controle da produção do espaço urbano e da habitação" surgiu em decorrência das epidemias de cólera e febre amarela na capital paulista. As reformas urbanas que ocorreram nesse período, promovendo obras de saneamento
} 
segunda guerra mundial, o congelamento de alugueis e a consequente menor oferta de moradias acessíveis os trabalhadores foram sendo pouco a pouco excluídos do direito à moradia e do direito à cidade ${ }^{6}$.

Diante da ineficácia do governo na produção de moradia acessível aos trabalhadores ${ }^{7}, 0$ aumento do número de proprietários graças à autoconstrução nos loteamentos periféricos das cidades brasileiras refletiu a importância que a casa própria adquiriu. Em São Paulo, por exemplo, até 1920, quando predominava como habitação popular as casas alugadas e os cortiços, 19\% dos domicílios na cidade eram próprios. Em 1940, quando já se presenciava a construção nas periferias, esse número aumentou para 25\%; em 1960, atingiu aproximadamente 60\% (BONDUKI, 1983) e, em 1974, alguns bairros populares da cidade de São Paulo apresentavam índices que chegavam a $75 \%$ de domicílios próprios (MARICATO, 1982).

Bonduki (2000) aponta que no Brasil, ao contrário de outros países da América Latina, como a Colômbia cujo governo, durante a década de 1960, assumiu a prática da autoconstrução para combater o déficit habitacional, essa modalidade de acesso à habitação ainda que tolerada não foi objeto de financiamento público e somente foi tratada como uma alternativa de produção da moradia pelos governos a partir de 1975 quando o Banco Nacional de Habitação (BNH) financiou lotes urbanizados destinados à autoconstrução dentro do programa Profilurb. Entretanto, a quantidade de unidades

básico conjuntamente com ações repressivas das polícias sanitárias justificadas pelo combate às epidemias, erradicaram os cortiços e expulsaram a população mais pobre dos centros das cidades (BONDUKI, 2002).

${ }^{6}$ A partir de 1940, em decorrência da crise econômica vivida no período do pós-guerra, reduziu-se a velocidade na construção de moradias em consequência da redução no fornecimento de material de construção (BONDUKI, 2002). 0 congelamento dos aluguéis, uma das medidas impostas pelo governo federal para regular as relações entre inquilinos e proprietários e que, em um primeiro momento foi interpretado como uma ação para reduzir o custo de vida do trabalhador, desmotivou a construção de habitações pelo capital privado (BONDUKI, 2002; MARICATO, 1997). A crise habitacional desse período "foi antes consequência de modificações estruturais no sistema produtivo e nas formas de provisão de moradia" (BONDUKI, 2002, p. 247). De acordo com a teoria da integração dos setores atrasados na acumulação do capital criada por Oliveira (2003), o Estado desviou a renda de outros setores para criar condições à expansão do parque industrial brasileiro.

7 Em 1937, o Estado iniciou a construção, pela primeira vez, de uma política de habitação social com a implantação dos Institutos de Aposentadorias e Pensões que até 1964, ano de seu término, financiou em todo o país, a construção de 140 mil unidades residenciais destinadas ao aluguel (BONDUKI, 2002; MARICATO, 1997). A Fundação Casa Popular, criada em 1946, teve resultados menos expressivos, totalizando até 1964 quase 17 mil moradias (MARICATO, 1997). Em 1964 foi criado o Banco Nacional de Habitação (BNH) como órgão central do Sistema Financeiro de Habitação. Operando com recursos do fundo dos trabalhadores, o FGTS e das cadernetas de poupança, o SBPE, o BNH foi pensando dentro de um plano de investimento para a construção de habitação popular, com a finalidade de solucionar o déficit habitacional do país por meio da aquisição da casa própria. Entretanto, durante seu desenvolvimento, o banco privilegiou a aplicação dos recursos no financiamento de habitação para as faixas de renda mais altas, desviando o foco da sua criação ao estimular 0 capital privado (VALLADARES, 1982). Durante sua existência, o BNH financiou "cerca de $25 \%$ das novas moradias construídas no país, porcentagem relevante, mas totalmente insuficiente para enfrentar o desafio da urbanização brasileira" (BONDUKI, 2008, p. 73). 
produzidas dentro dessa modalidade foi irrisória e revelou a política habitacional do período: 0 autofinanciamento da casa própria.

Magalhães (2009) assinala que entre 1940, quando existiam dois milhões de domicílios no país, até 0 ano de 2000, quando se contabilizavam 37 milhões, aproximadamente $80 \%$ das construções de novas unidades habitacionais foram realizadas sem financiamento habitacional e contaram com recursos das próprias famílias. Segundo o autor:

Somando todas as moradias que todos os governos (federal, estaduais e municipais) fizeram, encomendaram ou promoveram, incluindo as unidades construídas nos vinte anos de $\mathrm{BNH}$, mais os financiamentos da Caixa Econômica e dos bancos oficiais e privados: alcançam pouco mais de $1 / 5$ dos domicílios construídos no Brasil urbano. Ou dito de outro modo: $4 / 5$ das moradias foram erguidas contando apenas e exclusivamente com os recursos próprios das famílias (MAGALHÃES, 2009, s/p).

Diante da omissão do Estado, do arrocho salarial vivido pelos trabalhadores urbanos desde 0 golpe militar de 1964, e do encarecimento das terras urbanas decorrente da grande demanda, a busca por formas alternativas de se resolver o problema da moradia coube aos movimentos populares que ocuparam de forma massiva terras ociosas públicas ou privadas no início dos anos de 1980. Neste contexto surgiram as primeiras propostas autogestionárias na produção da habitação dentro dos movimentos de moradia (BONDUKI, 1992).

Entretanto, se as formas coletivas de produção da moradia conseguiram ganhar certo espaço dentro da política habitacional do país, com a inserção da modalidade de autogestão dentro dos programas do governo federal, como o Crédito Solidário e o Programa Minha Casa Minha Vida Entidades $^{8}$, a produção doméstica da moradia empreendida com recursos dos próprios moradores, por meio ou não da autoconstrução, nunca foi institucionalizada como um programa de grande alcance no país.

\footnotetext{
8 Em 2009, frente a um déficit habitacional de quase 6 milhões de moradias, aproximadamente $90 \%$ concentrava-se nas famílias com renda entre zero e três salários mínimos, o governo federal lançou o Programa Minha Casa Minha Vida PMCMV com o objetivo de incentivar a produção e aquisição de novas unidades habitacionais. A meta, instituída para as grandes empresas da construção civil, era a produção de um milhão de novas unidades em todo o país. As estimativas eram a redução do déficit habitacional de 7,13\% na faixa de renda familiar entre zero e três salários mínimos e de 99,63\% na faixa de renda de três a dez salários mínimos. (NASCIMENTO e TOSTES, 2011). A contratação da construção de um milhão de unidades foi atingida em 2010. A segunda etapa do PMCMV foi lançada em junho de 2011 tendo como objetivo a construção de dois milhões de unidades habitacionais contabilizando até o final de 2014 três milhões de unidades contratadas. ${ }^{8}$ Um trabalho recentemente publicado organizado por Lago (2013) analisa a política habitacional do país frente aos impasses a difusão dos programas de construção coletiva autogerida da moradia e as disputas presentes entre as grandes construtoras e as associações e cooperativas pelos recursos federais para a produção habitacional. Lago (2013) aponta que a produção associativa até o momento respondeu por apenas $2 \%$ dos recursos financiados para a aquisição da casa própria.
} 
A consultoria Booz Allen Hamilton, em estudo realizado para o setor da construção civil em 2003, apontou que a cada quatro novas unidades habitacionais produzidas no Brasil, por todas as faixas de renda, três foram realizadas por meio da autogestão. $O$ estudo apontou também que nesse mesmo período os financiamentos privados e governamentais para a compra dos materiais de construção destinados ao autoempreendimento da casa própria não somaram quatro bilhões de reais, enquanto 0 autofinanciamento foi em torno de 48 bilhões de reais (ASSOCIAÇÃO BRASILEIRA DE DESENVOLVIMENTO INDUSTRIAL, 2009).

Estes números, além de mostrarem o descompasso que existe entre os financiamentos públicos e as necessidades da população, principalmente as de mais baixa renda, comprovam que os recursos empregados pelas famílias na construção da casa de forma autônoma são bastante significativos.

O aumento do crédito para os financiamentos governamentais da compra do material de construção pela população de baixa renda não garante que as precariedades intrínsecas à autoconstrução desassistida não se reproduzam. Em 2007, dos 278 mil financiamentos realizados com recursos do FGTS, 30\% foram contratados pelas famílias com renda mensal entre zero e três salários mínimos para a compra de material de construção, sem ter sido atrelado a qualquer tipo de assistência técnica (ROLNIK e NAKANO, 2009)

Abramo (2001) demonstrou os altos investimentos nos materiais de construção das casas localizadas nas favelas do Rio de Janeiro. Segundo o autor, ao analisar a fala de um entrevistado, que declarou ter instalado no banheiro da casa uma torneira digna de cinema em detrimento do término do banheiro ou da instalação das divisórias de todos os dormitórios, evidencia que "a lógica de edificação da moradia depende do fluxo de recursos familiares e da opção de cada momento que não refletem um programa de investimentos e obras previamente estabelecido" (2001, p. 1580).

O documentário "Família Braz - Dois Tempos" lançado em 2011 relatou a história de uma família moradora da Brasilândia, bairro localizado na periferia de São Paulo, em dois momentos de suas vidas, 0 ano de 2000 e a década seguinte. As filmagens não apenas retrataram as conquistas pessoais dos integrantes da família, pai, mãe e quatro filhos, como também exibiram as modificações ocorridas na casa ao longo deste espaço de tempo. A casa, construída pelo pai, trabalhador da construção civil, e iniciada há mais de três décadas antes da primeira filmagem, é retrato das deficiências da autoconstrução desamparada. 
Ao mesmo tempo em que exibem as aquisições materiais dos moradores, em 2000 tinham apenas um carro, dez anos depois possuem quatro carros; são apresentadas as melhorias da casa térrea, em 2000, e com o segundo pavimento construído em 2010. O investimento na casa, com a construção de novos cômodos, apesar de ter trazido mais espaço para a família, consolidou novos "erros". É possível perceber a falta de privacidade, como o quarto das filhas por onde todos têm que passar para acessar os próprios quartos. A escada principal da casa, bastante estreita e com degraus cujos espelhos extrapolam os limites aceitáveis pelas normas construtivas, foi motivo de conflito durante sua construção e, segundo a mãe, é necessário fazer força para subir. De cima da última laje utilizada para a secagem das roupas, sem qualquer proteção vertical, os moradores sinalizam as barras de aço à espera de novas paredes enquanto narram seus planos de ampliações da casa.

Os altos índices de acidentes domésticos estão relacionados às obras inacabadas. Em 2002, os acidentes de quedas de cima de lajes foram responsáveis por $50 \%$ dos traumatismos cranianos e por $42 \%$ dos óbitos de crianças de até 14 anos (LEITE, 2002). Esse tipo de acidente também é causador de uma em cada três lesões na coluna, de acordo com o Instituto de Ortopedia e Traumatologia do Hospital das Clínicas de São Paulo (PORTAL G1, 2011).

\subsection{As formas de assistência técnica}

No Brasil, até hoje, é comum prefeituras fornecerem plantas padrões destinadas às famílias que pretendem empreender a construção de sua moradia. Esse tipo de serviço, segundo Maricato (1997), foi instituído pelas prefeituras já nas primeiras décadas do século XX. Segundo a autora, os desenhos, prevendo a construção de três cômodos, eram fornecidos aos trabalhadores para autoconstruírem suas casas em loteamentos localizados nos subúrbios.

O município de Campinas, por exemplo, por meio da Lei $n^{0} 7.653$ de 22 de outubro de 1993, autorizou o Departamento de Urbanismo da prefeitura a fornecer projetos para novas construções com área de até $70 \mathrm{~m}^{2}$. A lei estabeleceu as regras para acessar o benefício, dentre elas estão a apresentação do título de propriedade ou o compromisso de compra e de venda do lote registrado no cartório de imóveis, ter renda familiar não superior a cinco salários mínimos e o pagamento de uma taxa em torno de $\mathrm{R} \$ 130,00$ corrigida anualmente. A lei isentou o proprietário da apresentação de anotação de responsabilidade técnica pelo projeto e obra, ao mesmo tempo em que isentou a 
prefeitura municipal da responsabilidade de problemas decorrentes da ausência da assistência técnica. A lei ainda não permite que haja alteração de área construída implicando na perda dos benefícios.

Na prática, são ofertados seis modelos de plantas com áreas variadas contemplando apenas terrenos com topografias planas. Com a rigidez dos projetos que admitem poucas adaptações e desconsiderando a existência de terrenos com topografias acidentadas, essas plantas distanciam-se das necessidades reais dos moradores e da realidade presente nas periferias. É bastante comum encontrar casos onde as construções sofreram modificações em relação ao projeto original com acréscimos de áreas e, portanto, para conseguir o habite-se, documento indispensável para operar financiamentos, os proprietários precisam contratar os serviços de um engenheiro ou de um arquiteto e pagar todos os impostos e taxas dos quais foram isentos.

O Instituto de Pesquisas Tecnológicas, IPT, durante os anos 80, desenvolveu e publicou manuais destinados à autoconstrução. Voltados muito mais aos profissionais envolvidos em programas de assessoria técnica do que ao autoconstrutor, o material abordava as questões do planejamento, do projeto e da construção da casa (GUIMARÃES, 2005).

Em outra vertente, com foco muito mais comercial do que educativo, a Associação Brasileira de Cimento Portland, $\mathrm{ABCP}$, cuja missão é "consolidar e expandir o mercado de produtos e sistemas à base de cimento" (ABCP, 2013), desde 1989, publica folhetos e cartilhas com distribuição gratuita que abordam questões construtivas da linha do 'faça você mesmo' (Figura 1). Direcionados ao autoconstrutor, os textos, redigidos com linguagem simples, trazem muitas imagens que ilustram as etapas da construção, indicando dimensões e quantificando os materiais necessários em cada uma dessas etapas. Nestes manuais existem pequenas notas, normalmente localizadas no verso da capa, advertindo para a necessidade de contratação de um profissional habilitado, ao mesmo tempo em que, no decorrer de suas páginas, apresentam "dicas" que vão desde a escolha do terreno até a execução da cobertura da casa. Já foram distribuídos mais de 13 milhões de exemplares por todo o país (KANE WU; NAKAKURA, 2013). 

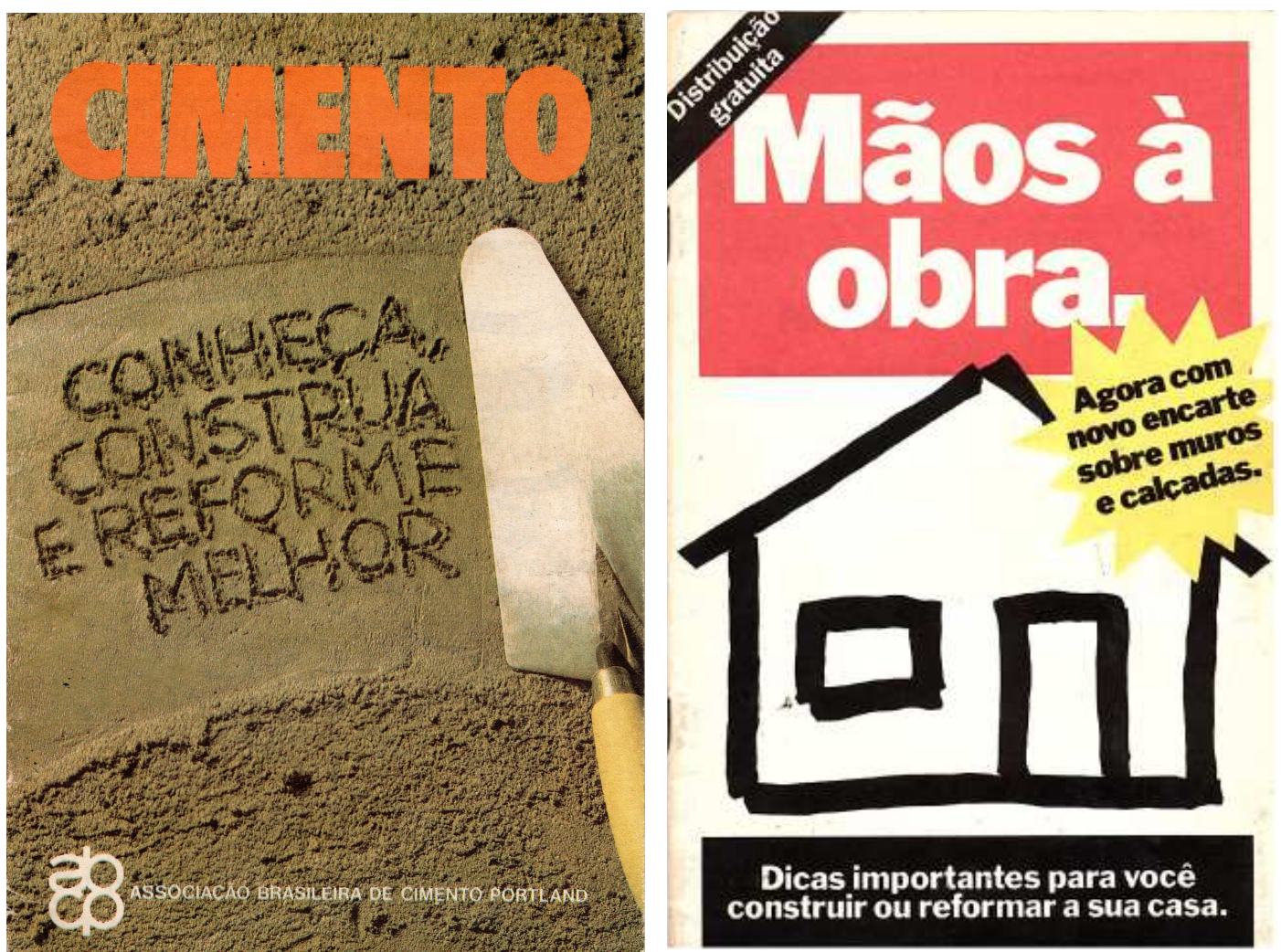

Dicas importantes para você construir ou reformar a sua casa.

Figura 1.Imagem dos manuais publicados pela ABCP direcionados ao autoconstrutor. Fonte: GOMES, 2013

A fidelização do autoconstrutor pelas indústrias de material de construção também se evidenciam em outros países da América Latina. No México, por exemplo, $60 \%$ de todo o cimento comercializado é absorvido pelos autoconstrutores e pelas pequenas empresas da construção (BOUILLON, 2012 apud Mayagoitia, 2009). Após uma crise econômica enfrentada pelo país, em meados dos anos de 1990, a Cemex, maior cimenteira mexicana, percebeu que suas vendas não tinham sido afetadas entre os consumidores formigas ${ }^{9}$. Logo após esse acontecimento, em 1998, lançou o programa Patrimonio Hoy cuja finalidade é a venda financiada ao autoconstrutor do material de construção à base de cimento juntamente com o serviço de assessoria técnica. Com o slogan 'cômodo por cômodo' e 'melhor um quarto a mais do que pagar renda aos demais' a venda é gradual e em quantidade suficiente para a construção de apenas um cômodo na casa. A tomada do financiamento acontece sempre em grupos de três a quatro pessoas, pertencentes à mesma comunidade, mas de núcleos familiares distintos; o público-alvo são famílias que ganham na média entre 5 a 15 dólares por dia sendo que nos quatro primeiros anos de funcionamento do programa foram financiados materiais suficientes para a construção de 36 mil cômodos (PRALAHAD, 2005).

\footnotetext{
${ }^{9}$ É o consumidor que compra o saco de cimento no varejo.
} 


\subsection{As leis de assistência técnica}

Em 2008, foi sancionada a Lei Federal $n^{0} 11.888^{10}$ que assegurou às famílias com renda de até três salários mínimos ${ }^{11}$ assistência técnica pública e gratuita a serem oferecidos pelos municípios de forma continuada por meio de equipe técnica própria, convênios com entidades de classe, associações sem fins lucrativos ou programas de extensão universitária. O objetivo da lei é garantir acompanhamento técnico para a elaboração do projeto e execução das construções destinadas à habitação, sejam elas construções novas, reformas ou ampliações.

Alguns municípios já tinham aprovado leis específicas instituindo a obrigatoriedade de assistência técnica à população de baixa renda. Em dezembro de 2002, o município de São Paulo aprovou a Lei no 13.433 de autoria do então vereador Nabil Bonduki, que dispõe sobre a prestação do serviço de assistência técnica à população de forma coletiva ou individualizada por meio de convênios entre o poder público municipal e pessoas jurídicas habilitadas. Em janeiro de 2004, Belo Horizonte publicou a Lei $n^{0} 8.758$ que promovia a assistência técnica pública e gratuita em arquitetura e engenharia à população com incapacidade financeira de acessar ao serviço. E após a sanção da Lei ${ }^{\circ}$ 11.888, podemos citar outros municípios que aprovaram leis visando à assistência técnica: Bauru (Lei $n^{0}$ 5.815/2009); Ribeirão Preto (Lei no 12.215/2009); Taboão da Serra (Lei no 1.846/2009) e Campinas (Lei n 13.886/2010).

Embora as leis municipais tenham reiterado a Lei Federal, em quase nada avançaram na efetivação da assistência técnica como um serviço público e gratuito. A falta de um modelo de atuação e gestão dos programas contribuiu para que o preceituado nos textos aprovados pelos legisladores municipais não fossem apropriados e incorporados institucionalmente para atender as necessidades da população e nem fossem implementados como parte da política habitacional.

A Lei Federal estabeleceu que fossem prioritários no atendimento os projetos idealizados sobregime de mutirão e aqueles implantados em áreas apontadas como de interesse social. Podem ser ofertados diretamente às famílias ou a grupos organizados em cooperativas e associações

\footnotetext{
${ }^{10}$ Em 2002 iniciou-se a tramitação no Congresso Nacional do primeiro texto instituindo a lei de assistência técnica pública e gratuita para a população de baixa renda.

${ }_{11}$ Segundo o IBGE (2010), a porcentagem de domicílios no Brasil com renda de até três salários mínimos é de 51,91\%, sendo que, a Região Norte possui 59,48\%; a Região Nordeste possui 70,46\%; a Região Sudeste é de 43,66\%, a Região Sul é de $42,88 \%$ e a Região Centro Oeste é de $47,53 \%$.
} 
comunitárias. A lei estabeleceu que o Fundo Nacional de Habitação de Interesse Social (FNHIS) ${ }^{12}$ deve custear a oferta dos serviços de engenharia e arquitetura dentro dos programas habitacionais financiados pelo fundo.

Em maio de 2010, o Instituto dos Arquitetos do Brasil - IAB lançou uma publicação para subsidiar os municípios na implantação dos programas de assistência técnica intitulada "Manual para a Implantação da Assistência Técnica Pública e Gratuita a Famílias de Baixa Renda para Projeto e Construção de Habitação de Interesse Social". O objetivo era criar um modelo para funcionamento e gestão dos programas de assistência técnica pelos municípios trazendo um passo a passo de como poderia ser ofertado o serviço. O manual também apontava as maneiras de acessar os recursos disponibilizados pelo governo federal por meio do FNHIS para subsidiar os programas municipais.

A Instrução Normativa $n^{0} 46$ regulamentou as diretrizes gerais e específicas para inscrições dos projetos de assistência técnica para habitação de interesse social, repasses e contrapartidas pleiteadas pelos estados, municípios e entidades privadas sem fins lucrativos. No manual que regulamenta a ação orçamentária vigente até 0 ano de 2011, foram apontadas duas modalidades de prestação dos serviços de assessoria técnica: elaboração de projetos para produção habitacional e urbanização de assentamentos precários; e assistência técnica para melhoria, conclusão e construção de unidades habitacionais. Enquanto a primeira modalidade se pauta nos empreendimentos habitacionais, a segunda modalidade engloba a contratação de serviço técnico para acompanhamento das obras de melhorias, conclusão e construção de unidades habitacionais podendo ser executados em regime de autogestão, mutirão ou autoconstrução exclusivamente por famílias moradoras em áreas de urbanização consolidada e assentamentos passíveis de regularização urbana e fundiária. A normativa define que o número mínimo de unidades a serem beneficiadas dentro da modalidade de melhorias habitacionais é de 40 domicílios, demarcados dentro de um mesmo polígono. Portanto, ainda que os projetos sejam individualizados, o acesso ao recurso deveria ser pleiteado de maneira coletiva.

A Caixa Econômica Federal criou uma Gerência Nacional de Assistência Técnica cuja estruturação foi iniciada em 2006. A assistência técnica à população de baixa renda aparece como um dos produtos ofertados pela entidade, devendo as propostas estar combinadas com programas de financiamento e microcrédito à compra do material de construção para 0 atendimento individual ou coletivo às famílias (CEF, s/d).

\footnotetext{
${ }^{12}$ A Lei Federal $n^{0} 11.124$ de 16 de junho de 2005 instituiu o Sistema Nacional de Habitação de Interesse Social, SNHIS e criou o Fundo Nacional de Habitação de Interesse Social e o seu conselho gestor.
} 
O Plano Nacional de Habitação, como instrumento de planejamento com horizonte em $2023 \mathrm{e}$ publicado em maio de 2010, define linhas programáticas estratégicas para combater os problemas habitacionais do país (MINISTÉRIO DAS CIDADES/SECRETARIA NACIONAL DE HABITAÇÃO, 2010). A assistência técnica é uma ação presente em quatro das cinco linhas programáticas ${ }^{13}$, sendo que uma delas trata exclusivamente de ações direcionadas ao atendimento de moradias construídas informalmente visando à melhoria do espaço físico dessas unidades. Essa ação consiste em viabilizar o acesso à aquisiçãa do material de construção conjuntamente com os serviços de assistência técnica. O texto cita que as fontes de recursos são o FNHIS, o Fundo de Garantia por Tempo de Serviço (FGTS) e recursos orçamentários dos governos estaduais e municipais.

Em 2009, durante $02^{\circ}$ Seminário Nacional de Assistência Técnica, Mirna Chaves, diretora do Departamento de Urbanização e Assentamentos Precários da Secretaria Nacional da Habitação do Ministério das Cidades declarou que entre os anos de 2007 e 2008, mesmo antes da aprovação da lei federal, estavam disponiveis $\mathrm{R} \$ 50$ milhões do FNHIS para serem contratados na modalidade de prestação de assistência técnica. Entretanto, pela falta de propostas apresentadas, apenas $R \$ 20$ milhões foram pleiteados (MISLEY, s/d).

Em novembro de 2012, durante $08^{\circ}$ Seminário Nacional de Assistência Técnica intitulado "A Gestão Municipal da Assistência Técnica no Brasil: Balanço e Propostas", foram discutidas as dificuldades e apontadas medidas - algumas já em elaboração - para a efetivação da assistência técnica como um serviço continuado dentro dos municípios.

De acordo com o relatório publicado após o Seminário, entre as propostas levantadas pelos diferentes representantes objetivando a consolidação de uma proposta de prestação de serviço público em arquitetura e engenharia estão: realização de uma campanha nacional com o objetivo de divulgar a lei e capacitar as prefeituras para criar e estruturar programas municipais, capacitar os municípios para pleitear recursos federais, gestão do programa e prestação de contas; elaborar estudos de avaliação de pós-ocupação; disponibilizar recursos para contratação de um profissional arquiteto ou engenheiro dentro do programa de crédito a compra de material de construção da CEF; estruturar os fundos estaduais e municipais para disponibilização de recursos que subsidiem o pagamento dos profissionais; desenvolver programas de capacitação de profissionais arquitetos e engenheiros para atenderem a população e vincular todos os recursos federais destinados a habitação ao Sistema Nacional de

\footnotetext{
${ }^{13}$ As cinco linhas programáticas são: Integração Urbana de Assentamentos Precários, Produção e Aquisição de Habitação, Melhoria Habitacional, Assistência Técnica e Desenvolvimento Institucional.
} 
Habitação de Interesse Social - SNHIS (DOS SANTOS et al, 2012). De acordo com o documento, desde 2011, não há liberação de recursos destinados a subsidiar a Assistência Técnica.

O relatório aponta como ação estruturante a consolidação do Sistema Nacional de Habitação de Interesse Social (SNHIS). De acordo com o relato:

\begin{abstract}
Atualmente a maior parte dos recursos destinados a habitação estão desvinculados do Sistema Nacional de Habitação (a partir do PAC e PMCMV) e portanto não passam pelas instâncias de gestão e controle como os fundos e conselhos nacionais, estaduais e municipais. A falta de democratização desta gestão contribui para o enfraquecimento do SNHIS e a desvinculação das ações de provisão habitacional em relação ao planejamento urbano (DOS SANTOS et al, 2012).
\end{abstract}

O descompasso presente entre a disponibilidade de recursos federais e as ações municipais é um dos reflexos da inoperância e falta de articulação dos programas de assistência técnica para melhoria das habitações da população de baixa renda. A maioria dos municípios não possui corpo técnico específico destinado à assistência técnica. As ações que se propõe ao atendimento dessa demanda se valem muito mais do esforço individual dos técnicos que trabalham nos órgãos municipais do que da institucionalização de programas que reconheçam na assistência técnica uma resposta à urgência do problema. Por outro lado, a descontinuidade dos recursos federais acaba por desacreditar que os programas de assistência técnica façam parte, verdadeiramente, da política habitacional do país.

\title{
1.3 Algumas experiências de assistência técnica de melhorias habitacionais
}

O conceito de melhorias habitacionais presente nesse estudo abrange todas as intervenções realizadas em moradias existentes que visam à melhoria da condição de habitabilidade do espaço construído como a ampliação da área construída; a melhoria das condições de iluminação e de ventilação; a melhoria das instalações hidrossanitárias; a correção de patologias construtivas; entre outros.

Ainda são poucos os programas de melhorias habitacionais direcionados à população de baixa renda. De iniciativa dos governos municipais, organizações não governamentais ou entidades de classe que de maneira pontual, nem sempre continuada, e, muitas vezes, desarticulada dos planos locais de habitação, buscam formas de viabilizar os serviços de assistência técnica a uma população 
cuja capacidade de mobilização de recursos humanos e financeiros próprios são bastante significativos.

Na cidade de Fortaleza, o programa Casa Bela, gerido pela Fundação de Desenvolvimento Habitacional de Fortaleza - Habitafor, oferta microcrédito para a população com renda entre um e três salários mínimos para a compra de material de construção destinado às melhorias físicas de moradias consolidadas. $O$ crédito, tomado de forma coletiva por grupos entre dez a 25 famílias organizadas pelas associações comunitárias, é de 900,00 por família ${ }^{14}$ e somente é liberado após levantamento físico e social, realização do projeto e do planejamento de como serão gastos os recursos (PREFEITURA DE FORTALEZA, 2013). Como os recursos são bastante limitados, o financiamento é realizado para pequenas reformas, como colocação ou troca de revestimentos, melhorias das instalações elétricas, hidráulicas e sanitárias, dentre outros. Instituído pela Lei Municipal 9.507/2009, os recursos destinados ao subsídio provêm do fundo de habitação do município. Já foram atendidas, entre 2005 e fevereiro de 2012, 2.866 unidades residenciais (PREFEITURA DE FORTALEZA, 2013). Pretende-se agregar recursos do governo do Estado do Ceará e também prever empréstimo para o pagamento da mão de obra e, dessa forma, a prefeitura pretende atender 40 mil unidades habitacionais até o final do ano de 2016 (O OESTE, 2013).

A Prefeitura Municipal de Taboão da Serra (PMTS), cidade pertencente à Região Metropolitana de São Paulo, desenvolveu com recursos do Programa de Subsídio à Habitação de Interesse Social (PSH) 15 ações de melhorias habitacionais concomitantes aos programas de urbanização de seis favelas do município ${ }^{16}$, totalizando aproximadamente 450 moradias. 0 critério para a participação era 0 grupo familiar de cada unidade residencial possuir renda mensal de até três salários mínimos. Em cinco favelas, para a elaboração dos projetos e para a execução das obras, foi contratada uma construtora diretamente pela instituição financeira responsável pela operação de crédito. Uma das favelas optou

\footnotetext{
${ }^{14} \mathrm{O}$ crédito é composto por subsídio de $350,00,100,00$ reais de contrapartida das famílias e o valor restante é financiado em até 18 prestações mensais de 25,00 reais.

${ }^{15} \mathrm{No} \mathrm{PSH}$, o repasse dos recursos é realizado diretamente às instituições financeiras habilitadas a operar o programa, que ficam responsáveis pela sua adequada aplicação. O PSH é uma parceria entre Governo Federal, por meio do Ministério das Cidades e Ministério da Fazenda, os estados e municípios, as instituições financeiras e os agentes financeiros do Sistema Financeiro da Habitação (SFH) e a população envolvida (pessoa física). Criado por meio da medida provisória 2.212, de 30 de agosto de 2001 e regulamentado pelo Decreto $n^{0} 4.156$, de 11 de março de 2002, portanto antes da Lei n 11.888/2008, tem como objetivo viabilizar o acesso à habitação para a população de menor renda familiar por meio de subsídios destinados à complementação do preço de compra ou construção da moradia. Os municípios e estados interessados em participar do programa devem cadastrar e organizar em grupos as famílias, apresentar proposta de participação no programa à instituição financeira habilitada e responsabilizar-se pela concepção do projeto do empreendimento habitacional e pela respectiva contrapartida necessária à sua viabilização. 0 subsídio, além de ser utilizado para o pagamento de material e mão de obra, também pode ser usado para cobrir gastos com assessoria técnica para os serviços de arquitetura e trabalho social.

${ }^{16}$ Saint Morritz I e II e Sítio das Madres I, II, III e IV
} 
pela autogestão dos recursos e autoconstrução das obras sendo a execução dos projetos e 0 acompanhamento da obra realizada por uma assessoria técnica contratada pela instituição financeira. $\mathrm{O}$ crédito por família chegou a $\mathrm{R} \$ 10.000,00$. Os projetos priorizaram solucionar deficiências estruturais; infiltrações; e instalações elétricas e sanitárias mal executadas.

Os técnicos da PMTS apontaram diversos problemas na execução das ações. Entre eles, a dificuldade no gerenciamento dos recursos e das obras pela comunidade que optou pela autogestão e o abandono do contrato pela primeira construtora contratada para a realização das obras nas cinco favelas. As assinaturas dos contratos junto às instituições financeiras ocorreram entre os anos de 2006 e 2008 e até o final de 2011 as obras não se encontravam concluídas (PMTS, 2012).

No Rio de Janeiro, a Secretaria Municipal de Habitação, utilizando recursos da União Européia, firmou convênio com o Instituto dos Arquitetos do Brasil - Departamento Rio de Janeiro (IAB/RJ) para ofertar à população residente de cinco favelas urbanizadas pelo Programa Bairrinho ${ }^{17}$ os serviços de assessoria técnica em arquitetura atrelada ao crédito para a realização de obras de melhorias físicas das unidades consolidadas dessas cinco comunidades (SILVA, 2003). A assessoria técnica em arquitetura era um dos passos a seguir nesse sentido ${ }^{18}$.

Nesse momento o IAB mantinha um Programa de Aprimoramento Profissional (PAP) que consistia numa espécie de residência universitária para que recém-formados em arquitetura com a supervisão de professores-orientadores. Por meio de seleção pública, o IAB-RJ escolheu 20 arquitetos recém-formados para realizar os atendimentos às famílias. Profissionais com mais tempo de experiência foram contratados para trabalharem como professores-orientadores. Todos receberam bolsas de estudos para, assim, garantir dedicação integral dos profissionais. Após a seleção, os arquitetos residentes receberam uma formação de três meses onde foram abordadas as questões construtivas e sociais com as quais iriam se deparar (ARRUDA; CUNHA; MEDEIROS, 2007).

A divulgação do programa e do seu funcionamento, dentro das comunidades atendidas, foi realizada porta a porta. Uma equipe de assistentes sociais antecipadamente esclarecia aos moradores as possíveis dúvidas e a forma de participação ao mesmo tempo em que inscreviam as famílias interessadas. Os atendimentos eram realizados na associação de moradores. Após a inscrição, os arquitetos entravam em contato com os moradores para o agendamento das visitas às moradias.

\footnotetext{
${ }^{17}$ O Programa Bairrinho é uma divisão do Programa Favela-Bairro para comunidades entre 100 e 500 domicílios.

${ }^{18}$ Parte das informações a respeito do programa contidas nessa pesquisa foram fornecidas por André Orioli que trabalhou como arquiteto-residente do programa, em janeiro de 2012.
} 
As intervenções prioritárias eram definidas no momento da avaliação da residência e do levantamento físico da mesma. Eram consideradas três questões centrais para execução do projeto: a segurança da construção para eliminação dos riscos iminentes, adequação das instalações sanitárias e o conforto ambiental.

O programa destinava um valor de $\mathrm{R} \$ 750,00$ por família para o pagamento da mão de obra empregada na execução das obras necessárias ao cumprimento do projeto. Os moradores inscritos no programa, em contrapartida, deveriam arcar com a compra dos materiais de construção. A mão de obra era contratada por valor orçado pelos arquitetos e poucos profissionais da construção civil se comprometeram com o serviço já que os valores a serem pagos estavam abaixo do valor praticado pelo mercado. Em casos de famílias muito pobres, foi autorizado o pagamento de mais $R \$ 750,00$ para a compra de material de construção (ARRUDA; CUNHA; MEDEIROS, 2007).

A atuação era realizada sempre em duplas. Um arquiteto era responsável pelo projeto e o outro contribuía na compreensão dos riscos que a moradia apresentava, além da ajuda durante 0 levantamento físico. Num próximo atendimento, as posições dentro da dupla se invertiam. Normalmente, os arquitetos elaboravam os projetos que seriam realizados com a verba inicial levando em consideração as questões prioritárias de salubridade e segurança e deixarem com as famílias atendidas um projeto mais completo, muitas vezes de ampliação da residência para o morador executar ao longo do tempo, conforme suas possibilidades.

Era previsto que as famílias tivessem acesso aos financiamentos para a compra do material de construção e, embora a Caixa Econômica Federal tenha se comprometido a facilitar o acesso ao crédito, apenas oito famílias receberam o crédito (ARRUDA; CUNHA; MEDEIROS, 2007).

Durante o seu funcionamento, em média, cada arquiteto responsabilizou-se por 30 projetos. Os projetos variaram pelo grau de dificuldade. Foram executados projetos muito simples, desde muros para sustentar a numeração predial da residência ou a execução de aberturas para garantir uma iluminação natural, até projetos mais complexos que envolviam reforços estruturais a instalações sanitárias. Um acompanhamento pós-reforma ocorreu de maneira informal pelo interesse dos próprios arquitetos. O programa, que tinha um caráter piloto, ocorreu entre 2001 e 2003 e pretendida atender 700 unidades habitacionais, contudo, ao final atendeu aproximadamente 400 famílias.

A partir dos exemplos apresentados, são perceptíveis os problemas enfrentados pelas iniciativas que se propuseram a construir programas de assistência técnica de melhorias habitacionais oferecidos à população de baixa renda. A Prefeitura de Fortaleza, que em sete anos não alcançou três 
mil unidades habitacionais atendidas, pretende até 0 ano de 2016 atender 40 mil unidades sem divulgar como será possível chegar a esse resultado. Nos programas desenvolvidos pela Prefeitura de Taboão da Serra, a falência da construtora e a falta de organização da comunidade para gerir os recursos fizeram com que os contratos assinados no ano de 2006 não estivessem concluídos até 0 final de 2011. O programa gerido pelo IAB foi finalizado e não conseguiu atender as 700 unidades previstas.

Dessa maneira, ciente das dificuldades enfrentadas pelas diversas experiências e da relevância do tema, serão apresentadas as experiências de Diadema (SP) e de Cuba com o objetivo de oferecer elementos propositivos para a elaboração de programas continuados e efetivos de assistência técnica de melhorias habitacionais à população de baixa renda no Brasil.

Nos próximo capítulo, analisaremos a experiência de assistência técnica empreendida pelo município de Diadema durante os anos de 2006 a 2008. 


\section{O caso do Brasil - O Programa Tá Bonito}

O presente capítulo tem como objetivo a análise da segunda fase do programa de melhorias habitacionais denominado Programa Tá Bonito, desenvolvido pela Prefeitura Municipal de Diadema (PMD) no núcleo Vila Olinda durante os anos de 2006 a 2008.

Para tanto, fizemos uso da bibliografia acerca dos programas de urbanização de favelas de Diadema e de estudos realizados após o processo de urbanização da favela Vila Olinda. Para discutirmos o desenvolvimento da segunda fase do Programa Tá Bonito dentro do núcleo, fizemos uso dos relatórios técnicos da Secretaria de Habitação da PMD, de entrevistas realizadas com a arquiteta19 da equipe do programa e com os moradores, além de visita a campo. As entrevistas com a arquiteta foram realizadas por meio de questionário escrito e de entrevista oral no local de trabalho da mesma. Também fizemos uso de registro pessoal em diário de campo.

Para discutirmos esse programa, faremos uma breve introdução sobre a formação urbana do município e as políticas públicas voltadas para a melhoria das condições de habitabilidade das favelas de Diadema. 0 Programa Tá Bonito, construído dentro desse contexto, visou a melhoria dos aspectos físicos dos núcleos urbanizados com o objetivo de criar melhores condições de habitabilidade da população de baixa renda e garantir a integração dessas áreas ao restante do município.

\footnotetext{
${ }^{19}$ A arquiteta optou por não ser identificada.
} 
No núcleo Vila Olinda, área escolhida para a realização do projeto piloto do programa, após serem realizadas com recursos próprios do município a melhoria externa de 39 unidades habitacionais, o município por meio de convênio estabelecido com a Caixa Econômica Federal (CEF) promoveu a melhoria interna de 45 unidades, 14 das quais atendidas pela primeira etapa do programa.

Após a realização da segunda fase do programa no núcleo Vila Olinda, o Tá Bonito foi replicado em outros núcleos e se deteve apenas às melhorias físicas das fachadas das moradias.

\subsection{0 contexto urbano de Diadema}

Nas últimas décadas, o histórico da cidade de Diadema se confundiu com as políticas públicas do município que visavam na urbanização das favelas um instrumento de melhoria da condição de vida da população. A partir da implementação de programas de urbanização e regularização fundiária, foram desenvolvidas ações como o Programa Tá Bonito, instituído em 2006 por lei municipal específica ${ }^{20}$, com objetivo de assegurar a melhoria física dos núcleos e assim integrá-los aos bairros.

Diadema é um dos 39 municípios que compõem a Região Metropolitana de São Paulo, com 386.089 habitantes (IBGE, 2010) e uma área de $30,7 \mathrm{~km}^{2}$, sendo atualmente a segunda maior densidade demográfica do país com, aproximadamente, 12.500 hab/km². Em 2010, o município possuía 117.379 domicílios particulares ocupados sendo que $21 \%$ do total encontravam-se em aglomerados subnormais²1 (IBGE, 2011).

Pertencente à região denominada de Grande $\mathrm{ABC}^{22}$, o desenvolvimento econômico e urbano de Diadema, a partir do final dos anos 40 , foi acelerado devido à sua localização geográfica por estar distante $17 \mathrm{~km}$ do centro da capital paulista, ter proximidade com a Rodovia Anchieta e ser atravessada pela Rodovia dos Imigrantes; acessos que ligam o município de São Paulo ao porto de Santos. Sua localização foi fator decisivo para a implantação de indústrias na região, principalmente voltadas ao

\footnotetext{
20 Lei N 2526 de 19 de junho de 2006. "Institui, no âmbito do Município de Diadema, o Programa Tá Bonito, de revitalização de núcleos e conjuntos habitacionais".

21 Segundo o IBGE, são considerados aglomerados subnormais o "conjunto constituído de, no mínimo, 51 unidades habitacionais (barracos, casas etc.) carentes, em sua maioria de serviços públicos essenciais, ocupando ou tendo ocupado, até período recente, terreno de propriedade alheia (pública ou particular) e estando dispostas, em geral, de forma desordenada e densa. [...] Os aglomerados subnormais podem se enquadrar, observados os critérios de padrões de urbanização e/ou de precariedade de serviços públicos essenciais, nas seguintes categorias: invasão, loteamento irregular ou clandestino, e áreas invadidas e loteamentos irregulares e clandestinos regularizados em período recente." (IBGE, 2011) ${ }^{22} \mathrm{O}$ Grande ABC é composto além de Diadema por Santo André, São Bernardo do Campo, São Caetano do Sul, Mauá, Ribeirão Pires e Rio Grande da Serra.
} 
setor automobilístico, de médio e de pequeno porte, que produziam peças e acessórios complementares às multinacionais instaladas em São Bernardo do Campo (COELHO, 2009).

A instalação das indústrias na região e as terras menos valorizadas que as dos municípios vizinhos atraíram a vinda de um número de trabalhadores superior à capacidade de implantação de uma infraestrutura urbana suficiente e adequada para atender a essa nova demanda (ABIKO e ALMEIDA, 1994). Entre 1960 e 1970, a população residente cresceu 540\% (COELHO, 2009).

Este crescimento da população ampliou a demanda de terrenos residenciais promovendo o encarecimento de terra e o afastamento dos moradores nelas residentes. Isto fez com que as favelas e a autoconstrução das casas em terras vazias de domínio público e privado com alto grau de risco ambiental, se apresentassem como alternativas para que os trabalhadores pudessem se manter próximos ao local de trabalho (COELHO, 2009). Segundo Abiko e Almeida (1994, p. 7),

De acordo com o estudo a respeito da situação habitacional do município, realizada pelo Departamento de Planejamento da Prefeitura de Diadema, em 1982, constatou-se a existência de 128 favelas, oitenta das quais (62,5\%) localizadas em áreas verdes e/ou de uso institucional dos loteamentos existentes no município, e o restante em terrenos particulares.

Em 1980, o cenário do município era composto por trabalhadores com baixo grau de escolaridade e mal remunerados, altas taxas de mortalidade infantil, condições de saúde precárias, um terço da população residente em favelas e cerca de $80 \%$ das ruas oficiais não pavimentadas (COELHO, 2009).

\subsection{A urbanização de favelas}

De experiências isoladas e como alternativas às políticas oficiais, a partir dos anos de 1980, os governos municipais passaram a estruturar políticas públicas de urbanização e regularização fundiária de favelas "respeitando a tipicidade de sua ocupação e propondo sua consolidação como espaço definitivo de moradia" (DENALDI, 2003, p. 71).

Segundo Denaldi (2003), Diadema foi um dos primeiros municípios do país a construir uma política de urbanização de favelas que garantisse a posse da terra à população juntamente com melhorias necessárias a consolidação dos núcleos ocupados. 
Entre os anos de 1983 e 1996, os sucessivos governos do Partido dos Trabalhadores optaram por realizar uma "urbanização gradativa" a partir do reconhecimento da posse e parcelamento do solo (DENALDI, 2003, p.85).

Com a publicação da Lei Municipal $n^{0}$ 819, de 12 de dezembro de 1985, Diadema instituiu a Concessão de Direito Real de Uso (CDRU) a ser outorgada aos moradores que ocupavam áreas públicas independente da conclusão das obras de urbanização como instrumento de garantia da posse da terra (DENALDI, 2003).

Os programas de urbanização e de regularização fundiária de Diadema ocorreram em três períodos: no primeiro, entre 1983 e 1988, foram contemplados os núcleos que necessitavam de pequenas obras de infraestrutura e cuja situação fundiária era simples de ser solucionada; no segundo período, entre 1989 e 1992, optou-se pelos núcleos que necessitavam de implantação de infraestrutura (redes de água e esgoto, drenagem e pavimentação) para serem consolidados e no terceiro período, entre 1993 e 1996, foram atendidos os núcleos mais precários que necessitavam de obras de engenharia de maior porte; como canalização de córregos, contenções de encostas, remoções e que ocupavam terras particulares (FUPAM-LABHAB-FAUUSP, 1999).

Coelho (2008) aponta que entre os anos de 1997 e 2000, com a perda das eleições pelo Partido dos Trabalhadores, houve uma desarticulação dos programas de urbanização de favelas. As intervenções nas favelas se caracterizaram, assim, pelo atendimento emergencial e ocorreram de maneira pulverizada; houve um retrocesso em relação à participação comunitária que perdeu espaço de diálogo com o poder municipal; as iniciativas de autogestão foram interrompidas; e os processos de regularização fundiária foram paralisados (COELHO, 2008).

Em 2001, com a retomada do Partido dos Trabalhadores ao governo municipal, os programas de habitação foram aos poucos reestruturados (COELHO, 2008).

As obras de infraestrutura necessárias à urbanização das favelas foram financiadas com recursos do Fundo Municipal de Interesse Social, Fumapis (DENALDI, 2003). O fundo, operado com recursos próprios da prefeitura, foi criado, no ano de 1990, pela Lei $n^{0} 1.093$ e objetivava também 0 financiamento para a construção de conjuntos habitacionais e para a compra de material de construção destinadas à edificação e às melhorias de unidades habitacionais precárias.

Segundo Denaldi (2003), a execução das obras de urbanização poderia ocorrer por administração direta, contratação de empreiteira, por mutirão e por autogestão. 
A organização comunitária era uma condição que precedia as intervenções e, em muitos casos, diante da insuficiência de recursos, essa organização foi importante para a execução total ou parcial das obras de urbanização em regime de mutirão assessorados pelos técnicos da prefeitura (DENALDI, 2003).

Denaldi (2003) aponta que a realização das intervenções por meio da autogestão consistiu na celebração de um convênio entre a PMD e a associação de moradores dos núcleos, para o repasse dos recursos financeiros do Fumapis destinados à execução das obras de urbanização. Segundo a autora, era de responsabilidade da associação de moradores a gestão dos recursos para a execução das obras de urbanização e a contratação de assessoria técnica para a elaboração do projeto de urbanização e de assessoria à autoconstrução. Entre 1993 e 1996, foram atendidas cinco favelas: Pablo Neruda, Macaúba, Caviúna, Santo Ivo e Vila Olinda, totalizando 1.650 famílias (DENALDI, 2003).

Em 1996, foi criado o Programa de Pós-Urbanização que tinha como foco o desenvolvimento comunitário na perspectiva de integração dos núcleos urbanizados com os bairros do entorno (DENALDI, 2003). Eram prioridades do programa: assistência técnica à autoconstrução; construção de centros comunitários; manutenção e aproveitamento das áreas livres para o desenvolvimento de atividades sócio-educativas entre outras ações (IDEM, 2011) ${ }^{23}$.

Segundo informações colhidas junto a arquiteta entrevistada, no início, o Programa de Pós Urbanização, que não foi instituído por lei específica, tinha como objetivo o desenvolvimento de um trabalho de pós-ocupação garantindo a integração física e social do núcleo com os bairros do entorno. Contudo, com as mudanças ocorridas no governo, como explicitado anteriormente, o programa se limitou ao desenvolvimento de ações sociais dentro dos núcleos urbanizados. A integração física dos núcleos foi viabilizada a partir da criação do Programa Tá Bonito, o objeto deste estudo.

Denaldi (2003), ao fazer um balanço dos resultados dos programas de urbanização de favelas de Diadema entre os anos de 1983 e 1996, apontou que, do ponto de vista da melhoria da condição de vida da população, o programa alcançou resultados mensuráveis, como a queda da mortalidade infantil, diminuição dos índices de violência, segurança da posse da terra pelas famílias e outros, não mensuráveis como o desenvolvimento comunitário com desdobramentos políticos, econômicos e sociais. Entretanto, a autora acrescenta que a falta de recursos humanos e financeiros consolidaram, entre outras situações inadequadas, os conjuntos de moradias precárias (algumas às margens de córregos ou ocupando a faixa de domínio da companhia de energia), os núcleos sem áreas destinadas

\footnotetext{
${ }^{23}$ Instituto Diadema de Estudos Municipais.
} 
ao lazer e à instalação de equipamentos comunitários e os núcleos sem a regularização fundiária concluída (DENALDI, 2003).

Em 2011, dos 219 núcleos existentes, 152 já se encontravam urbanizados, sendo que todos os demais núcleos do município já haviam sido objeto de algum tipo de intervenção, com exceção de sete que não estavam urbanizados (IDEM, 2011).

\subsection{0 núcleo Vila Olinda}

Localizado no bairro de Canhema, zona norte de Diadema e divisa com o município de São Bernardo do Campo, a urbanização do núcleo Vila Olinda foi iniciada em 1991 com o parcelamento dos lotes e concluída em 1996 com o término das obras de infraestrutura (FUPAM-LABHAB-FAUUSP, 1999).

Com uma população de 2.080 habitantes, o núcleo situado em sua maior parte em área particular e parte menor em área pública, tinha uma condição bastante precária antes da urbanização em decorrência do adensamento excessivo das casas, a maioria construída em madeira; das enchentes constantes pela presença de um córrego que margeava o assentamento e para onde eram lançados os esgotos; da presença de uma faixa de domínio da linha de alta tensão da companhia de energia que atravessava o núcleo e era utilizada como depósito de lixo e do relevo acidentado (FUPAM-LABHAB-FAUUSP, 1999).

A organização dos moradores do núcleo, reivindicando a posse da terra e a melhoria das condições de moradia, foi iniciada em 1989 e resultou na demarcação dos lotes e reassentamento das famílias (FUPAM-LABHAB-FAUUSP, 1999). O parcelamento do solo, a partir da decisão da comunidade de não realizarem remoções, demarcou, aproximadamente, 523 lotes com áreas de $42 \mathrm{~m}^{2}$ e vielas com inclinações entre $15 \%$ e $20 \%$ e largura de $3,0 \mathrm{~m}$.

Diante da decisão de não serem realizadas remoções, inviabilizou-se a criação de áreas verdes ou áreas de lazer, sendo que a única área permeável do núcleo era a faixa de $15 \mathrm{~m}$ de domínio da linha de alta tensão (FUPAM-LABHAB-FAUUSP, 1999). Devido às limitações para a ocupação dessa faixa, levantou-se a proposta de transformá-la em uma horta comunitária, contudo, ao final da urbanização, não se viabilizou essa intenção (FUPAM-LABHAB-FAUUSP, 1999). Segundo Denaldi (2003), durante a urbanização das favelas em Diadema, no momento em que o parcelamento do solo era realizado e a infraestrutura de saneamento instalada, os moradores iniciavam a construção de suas 
casas de alvenaria com recursos próprios a partir de plantas-padrão fornecidas pelo Serviço de Urbanização de Favelas, estrutura administrativa criada para implementar os programas de urbanização.

No caso do Vila Olinda, a autoconstrução das casas de alvenaria sem orientação técnica teve início logo que os lotes foram demarcados e as famílias reassentadas; sem mesmo terem sido implantadas as obras de infraestrutura do núcleo (FUPAM-LABHAB-FAUUSP, 1999). Diante dessa realidade e pela falta de técnicos da prefeitura para o acompanhamento das obras, foi firmado, em 1994, um convênio entre a PMD e a Associação de Moradores do Núcleo Vila Olinda para que esta última autogerisse os recursos destinados às obras de infraestrutura e também contratasse a assessoria técnica para o desenvolvimento do projeto de urbanização e de orientação à autoconstrução.

A assessoria técnica contratada foi a Peabiru24. De acordo com Yamaguti (2006), arquiteto da ONG, as funções da assessoria iam além das soluções técnicas, pois "o programa, apesar do nome [Apoio à Autoconstrução], compreendia também apoio à organização comunitária, trabalhos de educação ambiental e assessoria aos mutirões de infraestrutura urbana" (2006, p. 9).

Enquanto as obras de drenagem, canalização do córrego e contenção de taludes foram executadas pela PMD, os demais serviços de infraestrutura foram realizados pelos moradores, organizados em mutirão (FUPAM-LABHAB-FAUUSP, 1999).

Os recursos empregados na autoconstrução eram viabilizados pelos próprios moradores. Além da elaboração dos projetos personalizados de acordo com as necessidades de cada família, disponibilidade financeira e disposição dos lotes, os técnicos contratados forneciam aos moradores "informações básicas sobre a ocupação do lote, técnicas construtivas, materiais de construção, cuidados básicos a serem tomados desde a execução das fundações até o telhado" (YAMAGUTI, 2006, p. 10).

Os resultados desse programa no Núcleo Vila Olinda foram positivos em relação à participação da comunidade, principalmente devido aos mutirões organizados para a execução das obras de infraestrutura. (FUPAM-LABHAB-FAUUSP, 1999). No entanto, o programa não conseguiu chegar a tempo hábil para garantir a qualidade do espaço construído do núcleo como um todo, pois como aponta o documento que registrou a trajetória deste processo e a opinião dos profissionais envolvidos,

\footnotetext{
${ }^{24}$ Peabiru - Trabalhos Comunitários e Ambientais é uma Organização Não Governamental sediada no município de São
} Paulo que atua como assessoria técnica junto aos movimentos sociais de moradia. 


\begin{abstract}
No Vila Olinda, o grande avanço foi a comunidade gerenciar o projeto. Nas palavras do arqt. ${ }^{\circ}$ Hereda [Jorge Fontes Hereda, Secretário de Habitação e Planejamento Urbano entre 1994 e 1996], este contrato com a assessoria aconteceu muito tarde. Caso houvesse acontecido antes, a qualidade urbanística do núcleo poderia ser melhor. Para ele, 'o apoio a autoconstrução deveria ter acontecido antes. Deveríamos ter chegado antes com este programa, para dar um apoio maior na construção das casas. Acho também que deveríamos trabalhar melhor as áreas de lazer. Essa história de você ocupar todo o espaço com lote e aí você perder o espaço público como espaço de nucleação e área verde e tudo mais" (FUPAM-LABHAB-FAUUSP, 1999, p. 32).
\end{abstract}

Ao final da urbanização foram consolidados 573 domicílios, pois alguns lotes possuíam mais de uma unidade residencial (LABHAB - FAUUSP, 1999). Até o presente momento, não foi concluída a regularização fundiária do loteamento, como informou a arquiteta entrevistada, por ser particular a maior parte da área e estar o processo em andamento.

A partir dessa reconstrução histórica da formação do núcleo Vila Olinda contextualizada dentro dos programas de urbanização de Diadema, pode-se apontar que esse processo resultou na consolidação de precariedades construtivas, no adensamento excessivo e nas carências de espaços e de equipamentos urbanos.

\title{
2.4 O Programa Tá Bonito
}

Em 2006, foi aprovada a Lei Municipal n 2.526 que instituiu o Programa Tá Bonito, criado com o objetivo de empreender melhorias dos aspectos físicos nos núcleos urbanizados com a expectativa de integrá-los aos bairros.

Os objetivos específicos trazidos pela lei foram, entre outros, a reforma das fachadas das unidades residenciais e a requalificação dos espaços públicos dentro dos núcleos consolidados e passíveis de regularização fundiária, porém o programa só era posto em prática se a comunidade estivesse organizada e angariasse a adesão de no mínimo $60 \%$ dos moradores. A lei estabeleceu que essas ações fossem viabilizadas com variadas fontes de recursos, como aqueles oriundos do Fumapis, daqueles provenientes dos governos federal e estadual, com outros recursos destinados às políticas habitacionais e também por meio da contrapartida dos moradores.

A lei definiu ainda que a autogestão dos recursos e a contratação da assessoria técnica poderiam ocorrer diretamente pela associação de moradores ou pela PMD. De acordo com o texto, a assessoria técnica contratada seria a responsável pelos projetos de reforma das fachadas e pela orientação técnica aos moradores no que diz respeito às melhorias internas das moradias. Tais 
melhorias deveriam considerar a racionalização da construção, a ocupação adequada do lote, as condições adequadas de conforto ambiental, a eliminação de situações insalubres, a eliminação de situações de risco entre outras especificações. A assessoria técnica também seria responsável pela organização social da comunidade visando a capacitação e geração de trabalho e de renda.

Coelho (2006) explicita o significado do Programa Tá Bonito no contexto da dinâmica construtiva dos núcleos urbanizados ao pontuar que, "o programa significou uma gradual retomada da preocupação com a dinâmica da autoconstrução, com a aceleração do processo de verticalização nos núcleos habitacionais - o fenômeno da 'terceira laje' e ocupação intensiva do lote” (p.116).

A seguir apresentaremos o processo inicial do Programa Tá Bonito desenvolvido no núcleo Vila Olinda entre os anos de 2005 e 2010.

\subsection{A escolha da comunidade e as fases do programa}

Em 2005, foi desenvolvido um piloto do programa concomitantemente com a redação do projeto de lei. A comunidade escolhida para receber o Tá Bonito, em fase experimental, foi a Vila Olinda com 573 domicílios. Essa escolha se justificava pela capacidade de organização da comunidade, advinda da experiência de autogestão durante a urbanização, pela presença de uma grande quantidade de casas autoconstruídas e inacabadas e pela possibilidade de se finalizar a regularização dos lotes (PMD, 2008).

A proposta do programa consistia na reforma externa das moradias, restringindo-se às fachadas das casas. No entanto, no caminhar das execuções e em decorrência da viabilidade de crédito junto à CEF (Caixa Econômica Federal), o programa contemplou também as obras de melhorias internas das moradias (PMD, 2008).

O Tá Bonito não visava à construção de novas unidades residenciais, contudo, a partir do desenvolvimento do programa no núcleo, foram identificadas moradias em madeira bastante precárias e com recursos de uma dotação orçamentária do OGU (Orçamento Geral da União) estas foram substituídas por casas de alvenaria (embriões) ${ }^{25}$.

\footnotetext{
25 De acordo com a PMD (2008, p. 20) "O projeto para os embriões foi concebido de forma a viabilizar, com facilidade, futuras ampliações. Também foram previstas diversas composições de fachadas, com a utilização de caixilhos de padrão popular, possibilitando ao morador diversificar sua unidade. O projeto para os embriões busca ainda, introduzir conceitos de
} 
Para uma melhor visualização das intervenções realizadas no Vila Olinda desde o início do programa, nós as classificaremos em três etapas apresentadas a seguir:

- Primeira fase: foram realizadas obras de melhorias nas fachadas de 39 unidades residenciais durante 0 ano de 2005 com recursos próprios da prefeitura. Estas obras ocorreram com contratação de empreiteira;

- Segunda fase: foram realizadas obras de melhorias internas e externas de 45 unidades residenciais (sendo que 14 somente realizaram melhorias internas, pois já tinham participado da primeira fase) com recursos da PMD e CEF. Os projetos foram desenvolvidos pelos técnicos da prefeitura durante o ano de 2006; a obra ocorreu por autogestão (gerenciamento dos recursos pela Associação de Moradores) e foi utilizada mão de obra remunerada dos moradores do núcleo entre os anos de 2007 e de 2008;

- Terceira fase: foram construídas 16 unidades residenciais, embriões, em substituição às unidades existentes em madeira com recursos do Orçamento Geral da União e contrapartida da PMD. Os projetos e as obras ocorreram com contratação de empreiteira entre junho de 2008 e maio de 2010.

A Figura 2 espacializa as três fases do programa:

ecoeficiência, através dos seguintes pontos: aproveitamento da iluminação e ventilação natural, garantindo a salubridade das unidades; uso racional da água, através da utilização de tubulações e equipamentos de baixo consumo - como a bacia com caixa acoplada - e do reaproveitamento da água do banho na descarga; instalação de aquecedores solares de baixo custo (ASBC), para aquecimento da água, reduzindo o consumo de energia elétrica; utilização de materiais de baixo impacto ambiental, como tintas ecológicas e telhas recicladas; racionalização da obra, evitando o desperdício de materiais; a própria possibilidade de ampliação e adaptação, aumentando a vida útil da construção e amortizando o impacto ambiental; utilização do projeto para educar a comunidade sobre o impacto ambiental das edificações, apontando soluções para diminuí-lo". 


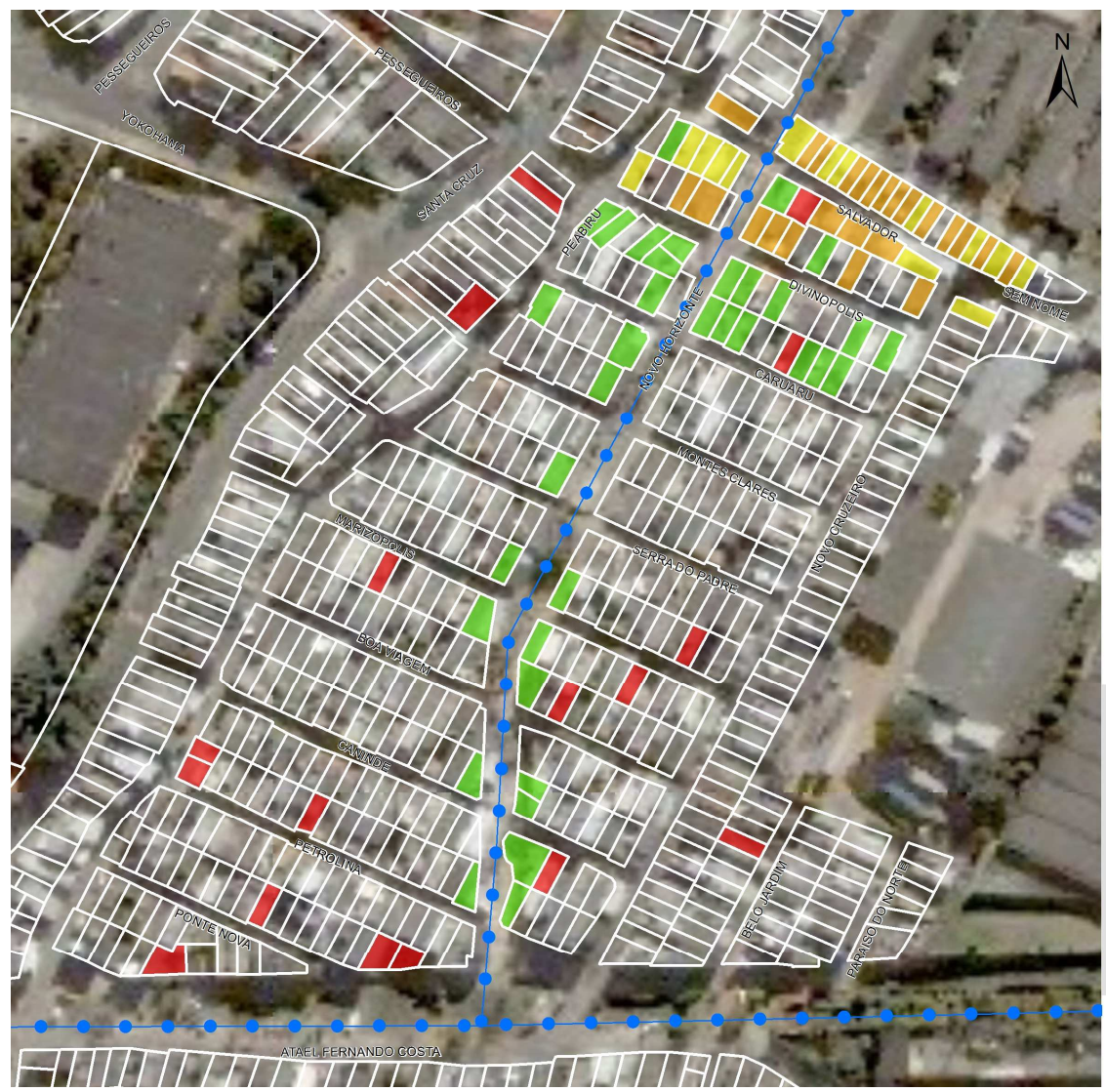

Programa "Tá Bonito" - Vila Olinda Diadema/SP

Legenda

$\bullet-$ Linha de alta tensão

Intervenções

Fases:

Fase 1

Fase 1 externo/Fase 2 interno

Fase 2

Fase 3 - embriöes

Figura 2. Espacialização das três fases do Programa Tá Bonito no núcleo Vila Olinda. Fonte: PMD, 2008

O recorte desta pesquisa se limitou ao estudo da segunda fase, por ser aquela que se envolveu a realização das melhorias internas das moradias mediante a prestação de assistência técnica pela prefeitura. A seguir apresentaremos os caminhos para a viabilização do programa e seus desencadeamentos e, em sequencia, as implicações práticas do projeto.

\subsection{Os procedimentos iniciais}

Concluída a primeira fase do programa que contemplou 39 moradias, a prefeitura em parceria com a CEF ampliou a possibilidade de recursos financeiros para garantir um maior número de unidades a serem atendidas na segunda fase. O programa Tá Bonito foi enquadrado dentro do programa Carta de Crédito Individual - Operações Coletivas - Aquisição de Material de Construção normatizado pela Resolução 460/04 e operado com recursos do FGTS26.

${ }^{26}$ A modalidade de crédito contratada junto à CEF, direcionada a famílias com renda entre 200 e 900 reais mensais, tinha como objetivo o financiamento da compra do material de construção acrescido de custos relativos à mão de obra especializada e assistência técnica para a construção, conclusão, ampliação, reforma ou melhoria de unidade habitacional e 
Para a tomada do crédito junto a CEF, existiam algumas exigências a serem cumpridas. Entre elas, a expedição do 'Habite-se'27 ao final da obra e a regularização fundiária dos lotes que à época ainda não se encontrava concluída. (PMD, 2008).

Frente à realidade da autoconstrução, era impossível exigir a responsabilidade técnica de edificações alheias a qualquer tipo de leis e normas edilícias e, dessa forma, decidiu-se que o 'Habitese' fosse substituído por um termo de habitabilidade expedido pela PMD, que atestava estarem as unidades em condições adequadas para a moradia (PMD, 2008).

Em relação à questão fundiária, acordou-se de que a ocupação era irreversível e a prefeitura se comprometeu a regularizar os lotes juntamente com as obras de melhorias das unidades (PMD, 2008). Contudo, até o presente momento, a regularização não foi concluída como explicitado anteriormente.

De acordo com a PMD (2008), após a execução do projeto, eram levantados os custos para a compra de materiais e a contratação de mão de obra para a elaboração dos contratos. Dentro do programa, cada família assinou individualmente o contrato junto a CEF com o valor do financiamento necessário para a realização do projeto da sua casa.

Por se tratar do atendimento de famílias de baixa renda, os recursos para essa modalidade foram compostos pelo valor do subsídio acrescido do valor do financiamento. 0 subsídio, recurso não reembolsável, variava de acordo com a renda, idade, valor do imóvel e valor da obra prevista em projeto para cada unidade habitacional. O financiamento correspondeu à contrapartida que as famílias deveriam investir para acessar o subsídio.

Segundo informações cedidas pela arquiteta, o objetivo inicial da segunda fase do programa era 0 atendimento de 50 unidades residenciais. Algumas famílias durante 0 processo de elaboração dos projetos ou ainda, durante a análise de documentação pela CEF desistiram do programa ou foram excluídas porque não se adequavam aos critérios de renda. A cada desistência era necessário inserir outra família e isso demandava novos projetos. Com as desistências, o grupo foi constituído por 45 unidades, sendo que 14 delas já haviam participado da primeira fase (PMD, 2008).

previa que $75 \%$ do valor total contratado devessem ser aplicados na compra do material de construção e os $25 \%$ restantes na contratação da mão de obra.

${ }^{27}$ É o documento expedido pela prefeitura que atesta ter sido a moradia construída de acordo com as exigências da legislação municipal. 
De acordo com a PMD (2008), conforme as especificidades de cada família e moradia, o valor do subsídio podia chegar a $R \$ 12.000,00$ (doze mil reais) por unidade e o financiamento foi calculado no valor de $\mathrm{R} \$ 1.500,00$ (mil e quinhentos reais) por unidade.

Como as famílias não conseguiram comprovações de renda nos moldes exigidos pela CEF, o governo municipal depositou, como caução, 0 valor integral do financiamento referente às 45 unidades numa conta da Associação de Moradores. As famílias teriam 72 meses para restituir o investimento feito pela prefeitura (PMD, 2008). 0 valor arrecadado deveria retornar ao Fumapis, contudo, segundo informações da arquiteta, esse valor ainda que tenha sido discutido inicialmente com as famílias, nunca foi cobrado.

Para acessar os recursos da CEF, foi necessário que a Associação de Moradores passasse por uma reestruturação jurídica, pois após o término das obras de urbanização do núcleo a associação perdeu importância e foi desconstituída juridicamente. Elegeu-se uma comissão de representantes dos moradores para gestão dos recursos junto à CEF (PMD, 2009).

A utilização de mão de obra remunerada dos próprios moradores do núcleo que já atuavam na construção civil foi entendida como elemento norteador para o desenvolvimento do programa. A partir desse consenso, três necessidades foram levantadas em relação aos trabalhadores: estarem inscritos na previdência social; receberem salários compatíveis com os praticados no mercado de trabalho; receberem capacitação de acordo com o trabalho a ser realizado (PMD, 2008).

Em relação à forma de contratação, os trabalhadores foram admitidos na qualidade de prestadores de serviços e, assim, ficaram segurados pela previdência social caso sofressem qualquer acidente. A remuneração mensal foi calculada com base no piso salarial estabelecido pelo sindicato dos trabalhadores da construção civil do ABC (PMD, 2008).

A capacitação dos 22 trabalhadores foi realizada por meio de parceria entre a prefeitura e 0 Centro de Educação do Trabalhador - Fundação Florestan Fernandes - com uma carga horária de 20h. 0 professor disponibilizado pela Fundação, durante as obras, assumiu também o papel de mestre de obras e assim deu continuidade à formação dos trabalhadores (PMD, 2008).

Com 0 início das obras, houve a necessidade de se rever alguns procedimentos. De acordo com a PMD (2008), a inexperiência dos trabalhadores e a dificuldade da realização das obras, devido à alta declividade dos lotes, à falta de espaço para circulação interna nas casas e a intervenção em moradias construídas de forma precária, decorreram numa baixa produtividade e atraso no 
cronograma. Muitos dos trabalhadores faziam "bicos" e não se dedicavam integralmente às obras. Diante disso e com a necessidade de seguir um cronograma tanto físico quanto financeiro, a remuneração da mão de obra passou a ser por produtividade (PMD, 2008).

Os valores destinados ao pagamento da mão de obra não foram suficientes para executar as melhorias em todas as unidades e, dessa forma, a prefeitura investiu uma espécie de contrapartida complementar em dinheiro (PMD, 2008).

Outras situações provocaram o aumento dos custos projetados. Segundo a PMD (2008), por se tratar de reformas em construções muitas vezes precárias, houve a necessidade de serem realizados serviços que não constavam no projeto e na planilha de custo. Ainda de acordo com a PMD, o encarecimento da obra também se justificou pela topografia dos terrenos bastante acidentada e pelas dimensões das vielas que não permitiam a passagem de caminhões, dificultando que a carga e a descarga dos materiais ocorressem distante das moradias e consumindo tempo da mão de obra. A necessidade de remoção das famílias, nem sempre de forma organizada, enquanto eram realizadas as obras, também causou atraso (PMD, 2008).

Segundo a PMD (2008), durante as obras, três casas de material de construção forneceram os materiais. O material bruto como cimento, cal, areia, brita foram comprados pela Associação de Moradores. Em relação aos materiais de acabamento, cada morador recebia da associação uma carta autorizando a compra da quantidade determinada em projeto e, a partir disso, escolhiam dentro dos valores orçados o tipo de revestimento desejado (PMD, 2008).

As obras foram iniciadas em março de 2007 e, de acordo com o cronograma, deveriam durar sete meses. No entanto, pelas situações relatadas (falta de mão de obra qualificada, dificuldade na entrega do material, necessidade de complementação da contrapartida) o processo apenas foi finalizado em abril de 2008, seis meses após o previsto (PMD, 2008).

\subsection{Assistência técnica: a elaboração dos projetos, os técnicos e os moradores.}

Nesta segunda fase do programa, por ser um projeto piloto e serem limitados os recursos disponíveis pela prefeitura, seria previsto atender 50 unidades das 573 existentes, conforme informou a arquiteta. Além dos recursos escassos, havia ainda certa resistência por parte dos moradores que desconfiavam do programa e não acreditavam na sua execução, como relatou uma moradora 
entrevistada "(..) quando o pessoal da prefeitura vinha atrás das pessoas tinha gente que...é complicado você convencer que alguém vai fazer melhoria na sua casa e ... para elas acreditarem que aquilo ali não vai ter que dispor de nada. (...) É bem assim". No entanto, apesar da desconfiança, existia a expectativa por parte dos técnicos e também dos moradores de ampliar o número de unidades atendidas caso o programa fosse executado como esperado.

A PMD elegeu os pontos prioritários a serem contemplados pela segunda fase do programa: 1) melhoria das condições de salubridade e habitabilidade internas das moradias; 2) melhoria do aspecto visual do núcleo; 3) participação da comunidade durante todo o processo; 4) capacitação profissional; 5) geração de trabalho e renda; e 6) reestruturação da associação de moradores (PMD, 2009).

Em relação à escolha das unidades que participaram da segunda fase, além da necessidade de comprovação de renda de acordo com os critérios do financiamento, priorizaram-se aquelas atendidas pela primeira fase que necessitavam de melhorias internas, como também as unidades ao longo da faixa de domínio da linha de transmissão de alta tensão, que colocava em risco a segurança dos moradores e era utilizada pela população como depósito de lixo. (PMD, 2008).

Quanto à ocupação dos lotes, de acordo com a arquiteta, como a segunda fase tinha como objetivo principal fazer melhorias nas construções existentes e não ampliações de áreas construídas, não foram pré-estabelecidos parâmetros de ocupação do solo28. Entretanto, em algumas unidades houve a necessidade de construção de novos cômodos devido ao adensamento excessivo das moradias $^{29}$.

Como informado pela arquiteta, compunham a equipe técnica da prefeitura, durante 0 desenvolvimento da segunda fase do programa, um coordenador, um arquiteto, uma assistente social e quatro estagiários, dos quais dois de arquitetura e dois da área social. Estes profissionais acompanharam todo o percurso do desenvolvimento da segunda fase do programa em caráter de dedicação exclusiva. Antes de iniciado o programa, a equipe desenvolveu um trabalho de aproximação da comunidade, como relatado pela arquiteta

Como este programa foi sendo construído junto à população, foram realizadas muitas reuniões durante o processo de construção da proposta e execução da obra. No ano de

\footnotetext{
${ }^{28}$ De acordo com a arquiteta entrevistada, as construções realizadas nas áreas demarcadas pelo plano diretor como Área Especial de Interesse Social (AEIS) seguem os parâmetros de ocupação estabelecidos pelo Decreto n $\mathrm{n}^{0} .767$ de 18 de dezembro de 1989 que regulamentou a CDRU. Estes parâmetros apontam às dimensões das áreas livres destinadas a insolação e a ventilação e o gabarito máximo da edificação. Contudo, grande parte das construções consolidadas não obedece ou extrapola os limites constantes no decreto, inviabilizando o cumprimento de tais normas.

${ }^{29}$ Segundo a Fundação João Pinheiro, 0 adensamento excessivo corresponde a existência de mais de três moradores por número de cômodos utilizados como dormitório.
} 
2006 quando estávamos preparando o material (projetos, cadastros, etc.) para viabilizar 0 financiamento da segunda etapa, iniciamos com Assembleias para informar sobre os objetivos do programa, esclarecer os procedimentos de levantamento das unidades e eleger os membros da Associação de Moradores. Quando os projetos foram elaborados, montamos reuniões menores com cerca de 10 famílias para discutir os projetos. Todas as informações sobre 0 andamento do contrato eram passadas periodicamente através das Assembleias. Acredito que as Assembleias ocorriam ao menos uma vez por mês. Além disso, mantínhamos um plantão na área para esclarecimentos de dúvidas que ocorria uma vez por semana. Com o início das obras em 2007, realizamos reuniões mensais para informar sobre 0 andamento dos serviços e prestar contas sobre a utilização do recurso. Também eram realizadas reuniões periódicas com os trabalhadores para resolver questões como qualidade dos serviços e pagamentos. Além disso, havia um grupo de famílias na área que recebia benefícios de um programa de transferência de renda do governo do estado (Renda Cidadã), acredito que eram 120 famílias. Este programa exigia como contrapartida o comparecimento de um membro da família em reuniões temáticas bimestrais (sobre segurança alimentar, violência doméstica, geração de renda, etc) que eram organizadas por nossa equipe social.

Quando indagamos a entrevistada sobre a percepção que ela tinha a respeito do papel do arquiteto para aquela população, foi trazida a tona a discussão sobre o estigma do arquiteto, aquele visto como o profissional que trabalha para as classes com maior poder aquisito, como comenta:

Em geral fomos bem recebidos pela população, mas me parece que o serviço do arquiteto ainda é visto como algo elitista. [...] Assim, parecia que os projetos dos arquitetos eram algo para uma classe social mais abastada, estando distante da realidade do núcleo. Apesar de estarmos sempre presentes na obra, notávamos, por exemplo, uma empatia maior dos moradores com o Mestre de Obras e o Coordenador do Programa (Técnico de Edificações).

A visão do arquiteto como aquele profissional que só trabalha para a elite, como materializada na fala da entrevistada, não é exclusiva da população de baixa renda. Segundo Ferreira (2011), ao discutir o papel do arquiteto dentro da sociedade brasileira, pontua que historicamente ao ser propagado (pela mídia e reforçado dentro das faculdades de arquitetura) como aquele profissional destinado ao atendimento de um restrito mercado formado pela alta renda se distanciou da realidade brasileira e "fracassou no seu papel social", como destaca:

É a única conclusão que se pode tirar ao olhar para um país onde, em média, $40 \%$ da
população urbana vive precariamente, sem arquitetura nem urbanismo. Uma tragédia, que
deveria tirar o sono dos arquitetos. A arquitetura e o urbanismo, quando vistos como uma
profissão central na sociedade, que reflete e propõe a organização do território e do espaço
construído, tem uma vocação indiscutivelmente transformadora. Porém, para além das boas
obras de autores individuais, ela indiscutivelmente não foi capaz de sustentar uma
urbanização decente no nosso país ( $\mathrm{s} / \mathrm{p}$ ) Diante disso, a oferta de assistência técnica a uma população que desconhece o papel do arquiteto dentro da prática da autoconstrução, constituída historicamente sem a presença desse profissional, é um desafio a ser transposto, pois anterior à apresentação de uma proposta de intervenção há um trabalho de aproximação junto à população. 
Esse distanciamento entre arquiteto e população, no caso do Vila Olinda, foi também reforçado pela forma de apresentação do projeto pelos técnicos, que não se diferenciou daquela praticada para uma classe que se utiliza dos serviços deste profissional.

Como explicou a arquiteta, a elaboração do projeto era precedida pela visita técnica na moradia, onde o arquiteto, ao realizar o levantamento físico, apontava as situações de insalubridade, de riscos e de adensamento excessivo. A partir disso, elaborava-se o projeto e este era apresentado em planta baixa, cortes e fachadas (Figura 3) para discussão junto aos moradores, como relata:

No caso da Vila Olinda [...] apresentamos somente os projetos (planta e corte) e os Estudos Cromáticos (Elevações com a proposta de pintura). Para o PSH [Programa de Subsídio à Habitação de Interesse Social], que foi realizado posteriormente no Núcleo D. João VI [núcleo atendido pelo Programa Tá Bonito durante os anos de 2010 e 2011], produzimos algumas maquetes para que os moradores conseguissem visualizar melhor a questão dos poços de ventilação.

Como pontuado pela entrevistada, a dificuldade dos moradores em compreender o material apresentado provocou uma mudança de atitude por parte dos técnicos que se utilizaram da maquete para representar as melhorias propostas para as fachadas em outro núcleo. Contudo, no ponto de vista da arquiteta, apesar dos esforços empregados, os moradores não conseguiram ter real clareza da proposta.

Em relação ao Vila Olinda, uma parte dos moradores somente conseguiu compreender o que foi proposto durante a realização das obras, como consta no relatório da prefeitura

no momento da assinatura dos projetos, apesar da participação ativa da equipe técnica, não houve, em alguns casos, real clareza das propostas apresentadas por parte dos beneficiários que, ao início das reformas, demonstravam que os serviços propostos não atendiam de forma efetiva suas expectativas (PMD, 2008, p. 16).

Souza (2007), em sua pesquisa sobre a participação do morador durante os processos de elaboração dos projetos habitacionais de interesse social, apontou a dificuldade da comunidade em compreender as representações em plantas das moradias que seriam construídas. De acordo com 0 autor, a dificuldade da leitura da representação tradicional foi superada ao serem propostos maquetes em escala real. Diante disso, enfatizou-se a necessidade em "se manter sempre uma correspondência entre a representação na escala reduzida e na escala humana" para que os moradores envolvidos no processo de discussão ao compreenderem essa correspondência estejam aptos a participar com mais autonomia do processo de discussão do projeto (SOUZA, 2007, p.161).

A metodologia discutida pelo autor se refere a uma proposta para construção de novas unidades habitacionais. No entanto, a dificuldade encontrada na leitura da planta é semelhante às 
dificuldades de compreensão pelos moradores do núcleo Vila Olinda das intervenções propostas, o que nos dá indícios da necessidade em se discutir formas menos abstratas, como o uso das plantas ou mesmo as maquetes, e elaborar maneiras mais concretas, como a simulação das intervenções em escala real, para que se possibilite o diálogo entre técnicos e moradores para a discussão do projeto.

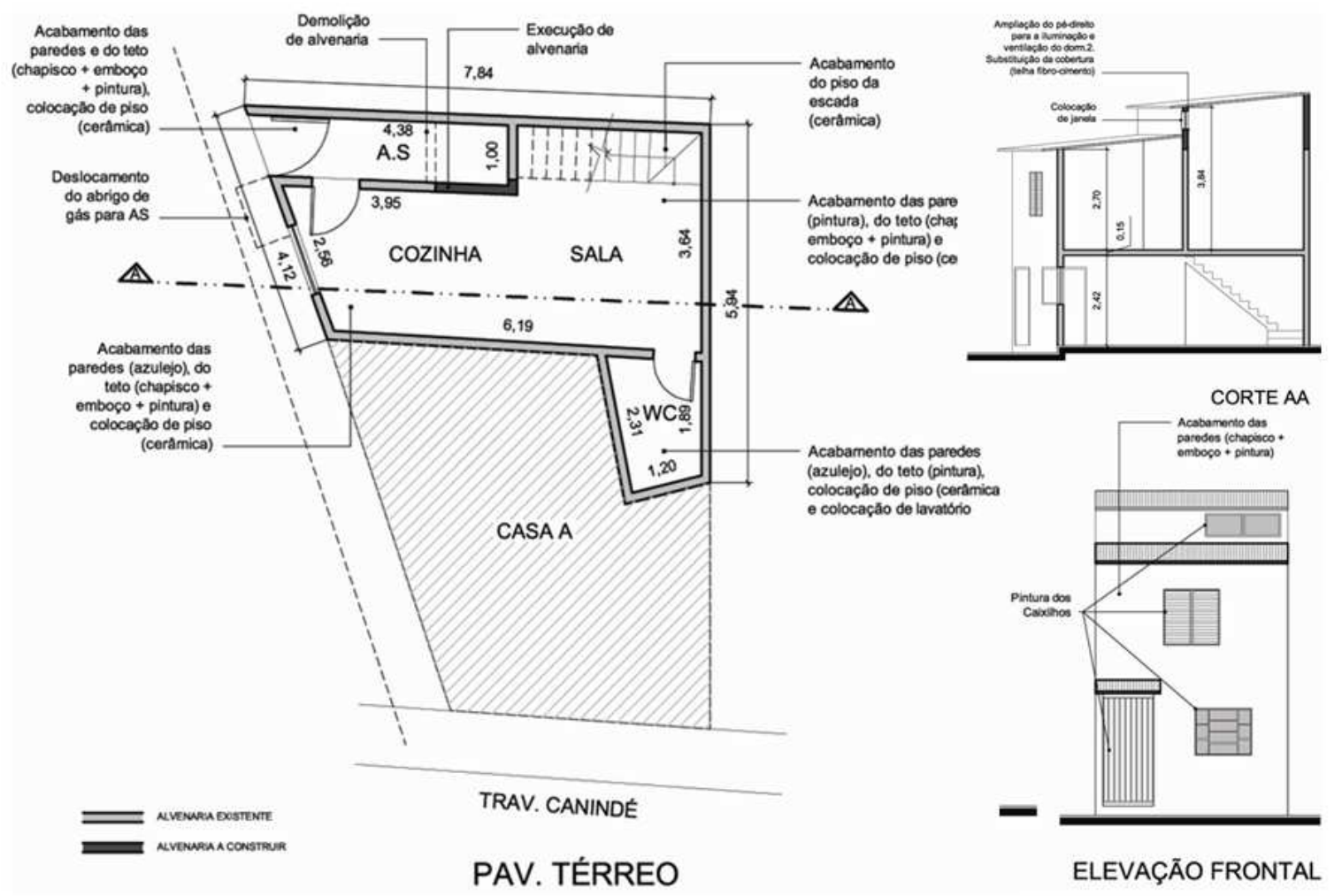

Figura 3. Exemplo dos desenhos elaborados com as intervenções propostas e apresentados às famílias. Fonte: PMD, gentilmente cedidas pela arquiteta.

Não apenas a dificuldade da leitura do material gráfico é um ponto a ser considerado, como também o exercício da discussão entre técnicos e moradores das prioridades do programa. Na visita ao núcleo, alguns entrevistados relataram não terem acontecido momentos de "negociação" entre o que eles desejavam modificar nas moradias e aquilo que na prática era possível ser executado, levando-se em conta os recursos disponíveis e as prioridades estabelecidas pelo programa. Nas palavras dos moradores, o projeto "chegou pronto", o que pode ser indício da falta de entendimento do próprio processo de discussão do programa, pois o fato de não serem executados pelos técnicos os desejos dos moradores não invalida o processo de "negociação". Segundo a PMD (2008, p. 23) "havia certa dificuldade em alguns moradores em compreender como funcionava o programa e porque não era possível atender todas as suas expectativas". 
Uma prática recorrente da autoconstrução nas favelas refere-se ao aproveitamento máximo da área do lote. Abramo (2001), em seus estudos sobre os componentes para a formação do preço dos imóveis das favelas cariocas, reconhece a existência de uma estratégia praticada pelos moradores baseada na ideia de quanto maior o investimento na edificação, além de implicar no aumento do bemestar dos usuários torna mais efetiva a ocupação.

No caso do Vila Olinda, pela configuração dos lotes com área, em média, de $42,00 \mathrm{~m}^{2}$ a ocupação máxima dos mesmos é uma constante encontrada nas moradias. As propostas apresentadas pelos técnicos para solucionar problemas advindos da falta de ventilação e iluminação adequadas implicaram na diminuição da área útil da moradia e causaram resistências por parte dos moradores ao projeto, mesmo quando argumentado sobre os benefícios à saúde como pontua a arquiteta:

Acredito que algumas de nossas propostas, principalmente as relacionadas à melhoria de
iluminação e ventilação, ou melhoria em escadas, que acarretavam em perda de área útil
(poços de ventilação ou escadas mais confortáveis ocupando mais espaço), ou até mesmo
os projetos cromáticos, às vezes não agradavam a população por irem contra as práticas
estabelecidas na autoconstrução em assentamentos precários.

A entrevistada se refere à resistência dos moradores em aceitar as intervenções que propunham grandes transformações naquilo autoempreendidas por eles próprios, uma vez que essas demandaram recursos financeiros, recursos humanos e tempo. Esse é um ponto delicado quando se trata de intervenções realizadas em moradias autoconstruídas porque 0 arquiteto, ao não saber negociar esse tipo de melhoria, provoca a recusa do projeto por parte do morador.

Ainda a respeito das especificidades da assistência técnica voltada às melhorias habitacionais, não apenas em relação à linguagem do projeto, mas no que tange a formação do profissional, a arquiteta reconhece a dificuldade que possui em apresentar soluções para algumas patologias construtivas identificadas nas moradias devido à diversidade com que elas se apresentam e a dificuldade em identificar as causas, pois essas não se limitam a análise da moradia de maneira isolada. $\mathrm{O}$ adensamento construtivo em decorrência das dimensões restritas dos lotes, como já observado, potencializa essas dificuldades apontadas pela arquiteta.

Nesse sentido, a formação do profissional que opta pela assistência técnica para baixa renda deve ser diferenciada, pois seu universo de trabalho é bastante específico. A formação do profissional deve ser tão ampla e múltipla quanto os desafios a ele atribuídos, como discute Ferreira (2011)

[...] Um arquiteto que queira fazer frente aos desafios que o Brasil hoje the apresenta deve ser um bom projetista, sem dúvida, mas deve entender da história econômica e social da nossa formação nacional (para compreender as causas dos problemas que enfrentará), deve transitar pelo campo da legislação urbanística, deve conhecer aspectos básicos de 
engenharia ambiental, deve saber de economia urbana, e assim por diante. Deve tornar-se um cidadão, um ser político capaz de colocar-se ativamente nas discussões sobre nosso futuro, em especial no que diz respeito ao ambiente construído [...] (s/p)

Segundo a PMD (2008), o tempo decorrido entre o levantamento físico das unidades e o início das obras foi de um ano. Neste intervalo, parte dos moradores realizaram com recursos próprios alguns serviços apontados em projeto. De acordo com a arquiteta, os serviços realizados eram aqueles que os moradores possuíam mais domínio para executar como a colocação de revestimento cerâmico. Entretanto, foi relatado que em uma das unidades, durante este período, houve a construção de um novo pavimento.

Esse fato aponta dois aspectos a serem levantados, o primeiro diz respeito à importância da coordenação de todas as etapas e dos prazos necessários para alcançar cada uma delas, colocando os moradores beneficiados como corresponsáveis pelas informações constantes nos contratos. Apesar do programa não ter viabilizado um escritório dentro da comunidade, existiu a disponibilidade dos técnicos em fazerem plantões semanais no núcleo para esclarecimento das dúvidas sobre o programa e atualização do andamento dos contratos com a CEF, conforme relato da arquiteta já mencionado.

O segundo aspecto diz respeito à capacidade que alguns moradores possuíram de levantar recursos próprios para executarem as obras. Uma moradora entrevistada, beneficiada pelo programa, relatou como o pai, trabalhador da construção civil, obtém recursos para realizar as reformas constantes na casa:

\footnotetext{
Ele [pai] trabalha por conta, né, então sempre tem gente chamando pra fazer alguma coisa. Ele vai e cobra o preço dele. Normalmente nessa área [construção civil] as pessoas quando trabalham por conta acabam ganhando bem. Então na hora que ele quer, ele vai lá e cobra o preço dele. Às vezes precisa juntar um pouco mais [recursos], compra e faz. Na verdade, nessa área só não ganha dinheiro quem não quer.
}

A fala da moradora aponta para a possibilidade que, para alguns moradores, aqueles que conseguem juntar recursos, a assistência técnica também poderia ocorrer de forma desvinculada de programas de subsídio público.

A efetivação da assistência técnica como uma política pública, funcionando de forma independente da vontade política ou marca de governo, poderia prevenir situações que além de potencializarem recursos mal empregados, colocam em risco a vida dos moradores, como mencionou a moradora:

$\mathrm{Na}$ verdade dentro do Vila Olinda eu acredito que ninguém pede assessoria, nem da prefeitura, não tem acompanhamento de arquiteto, todo mundo faz por conta própria. Inclusive no início do projeto [início das obras do programa] teve uma casa que...não sei te 
explicar as razões, mas a fundação dela estava comprometida e teve que derrubar tudo, refez a casa.

Entretanto, quando indagada se acreditava que os moradores fariam uso do serviço do arquiteto para acompanhar as intervenções executadas com recursos próprios nas moradias, ela disse acreditar que este serviço não seria utilizado, como relata: "olha, talvez algumas pessoas, mas a maioria eu sinceramente acredito que não porque a maioria das pessoas não gostam de seguir regras, entendeu. Eu acredito que não, posso estar enganada [...]"

A fala traz indícios de que essa seja a concepção que os moradores constroem a respeito da função do arquiteto, "aquele que vai ditar as regras". Essa ideia é reforçada no relato de outro morador que foi empregado como eletricista no programa e afirmou que para ele seria bom ter uma assistência técnica constante no núcleo. No entanto, ainda segundo o entrevistado, para outros moradores poderia não ser positivo, pois essa presença constante impediria as casas de terem três lajes ou de alguns moradores se apropriarem das calçadas enquanto apontava para uma casa cujo portão ia até o limite da calçada com a guia. Para este morador, o reconhecimento do papel do arquiteto foi construído na relação com os técnicos durante as obras a ponto de relatar que compreendeu a importância do projeto e da presença dos profissionais, pois sentiu maior facilidade em desenvolver seu trabalho.

Segundo a arquiteta, no decorrer do Programa Tá Bonito, durante as assembleias eram divulgadas a disponibilidade dos técnicos em atender aos moradores que não participavam do programa, mas almejavam fazer melhorias internas:

\begin{abstract}
apesar de nos colocarmos à disposição para assessorar nas melhorias internas, inclusive divulgando isso em reuniões, raramente somos procurados pela população para executar este tipo de projeto. Na verdade, apesar da Secretaria de Habitação não possuir um corpo técnico específico para prestar assessoria técnica aos moradores em melhorias na unidade habitacional, como previsto também na Lei de Assessoria Técnica [Lei Federal $\mathrm{n}^{011.888 /}$ 2008], estamos à disposição da população e atendemos sempre que solicitado, estando a área ou não no programa de requalificação habitacional. Acredito que a população não tem muito conhecimento deste direito e/ou acredita que o serviço do arquiteto/engenheiro não se aplica aos Núcleos Habitacionais.
\end{abstract}

Pela fala da arquiteta, a Secretaria de Habitação não possui uma equipe técnica voltada para este tipo de assistência, entretanto, esta se dá devido à boa vontade da equipe que disponibiliza os seus serviços como mais um dos afazeres de suas funções. A entrevistada retoma a lei federal que assegura às famílias de baixa renda o acesso contínuo da assistência técnica, no entanto, o Poder Público não disponibiliza recurso humano suficiente para se por em prática a lei. 0 resultado desse desequilíbrio entre a lei e a prática perpassa a falta de conhecimento da população a respeito do direito de acesso ao serviço. 
Entretanto, de acordo com a profissional, há casos em que a entrega de projeto e a disponibilização de orientação técnica pela prefeitura não são suficientes para garantir a execução da obra pelos moradores de acordo com os parâmetros construtivos necessários as condições mínimas de salubridade. Pela experiência da arquiteta, para se assegurar o cumprimento dos parâmetros de conforto e de salubridade, o ideal seria vincular o projeto ao acompanhamento da obra:

\begin{abstract}
já tivemos experiências com loteamentos populares, onde o morador recebia o lote para construir por conta própria. Fornecíamos um projeto padrão, orientando sobre a necessidade de manutenção de áreas mínimas de ventilação/iluminação e áreas máximas a construir, mas acredito que em pelo menos metade dos casos os parâmetros não foram seguidos [...] os moradores visam 0 aproveitamento máximo do lote, muitas vezes transformando 0 espaço em mais de uma moradia, sem preocupação com as condições de salubridade [...] Acredito que o simples fornecimento do projeto, sem o acompanhamento da intervenção, não garante sua execução. Vincular o projeto e o acompanhamento da obra a uma linha de financiamento/subsídio governamental me parece uma alternativa interessante, pois garante que a obra seja executada com o mínimo de qualidade e em conformidade com o projeto.
\end{abstract}

Atrelar a assistência técnica ao financiamento pode ser sinônimo de garantir que a obra sairá de acordo com o projeto, ao fiscalizar o cumprimento das etapas planejadas e do emprego adequado dos recursos e ao pairar o risco de descontinuidade do financiamento caso algumas premissas não sejam cumpridas.

Contudo, o grande impasse para que os programas de assistência técnica de melhorias habitacionais atrelado ao financiamento ganhem escala é a dificuldade na realização das obras, como comentou a arquiteta:

A personalização dos projetos requer tempo e recursos. Mas ainda acredito que o maior problema está na realização das obras. A obra de requalificação é extremamente difícil, demorada e cara, pois além da personalização, as condições de trabalho em Núcleos Habitacionais são bastante adversas (vielas estreitas e íngremes) e há grande dificuldade na contratação de mão de obra para este tipo de serviço.

A dificuldade está em mensurar os imprevistos ao se intervir em construções alheias aos parâmetros edilícios. No entanto, essa dificuldade é um desafio a ser ultrapassado, mas não pode ser paralisante. Se essa situação é vista como o ideal de assistência técnica a ser disponibilizada à população, não podemos nos esquecer de que o cenário formado pela autoconstrução desassistida é dominante na paisagem da maioria das cidades brasileiras. Portanto, a capacidade de capitalizar recursos por uma parte da população, como já observado na fala de uma das moradoras, não deve ser desconsiderada.

O programa de assessoria técnica à autoconstrução desenvolvido no núcleo durante a urbanização na década de 1990 é indício de que existe outra possibilidade de prestação dos serviços 
de arquitetura e que, provavelmente, se não fosse interrompida, a qualidade construtiva das moradias seria diferente do cenário atual.

O presidente da Associação de Moradores comentou que embora não tenha sido um dos beneficiados pelo programa acredita na importância da orientação técnica aos moradores. Relembrou de quando fez uso do serviço dos arquitetos no momento em que a Peabiru foi responsável pela assessoria do programa de urbanização e de apoio a autoconstrução. Na ocasião, a Peabiru manteve os arquitetos trabalhando diariamente no núcleo por quase dois anos, no salão comunitário da Igreja.

Segundo o morador, as casas que receberam a orientação da Peabiru é que ficaram "construídas mais direitinhas", como relatou. Ele mesmo pediu orientação aos arquitetos quando percebeu a presença de umidade no pavimento térreo da sua moradia, usado como comércio. $A$ orientação dada foi fazer um vão até a laje de cobertura do último pavimento para proporcionar uma melhor circulação do ar. 0 morador comentou que não relutou em executar o que foi proposto, mesmo que tenha implicado na diminuição de área útil, pois ele confiava nos técnicos. Completou dizendo que a assessoria foi tão benéfica para o núcleo que nomearam uma das ruas de Peabiru. Quando questionado se os moradores se utilizariam dos serviços dos arquitetos caso a assistência técnica fosse contínua, ele enfatizou que nesse momento seria bom ter um arquiteto para orientá-lo sobre um novo ponto de umidade no comércio.

O vínculo criado entre moradores e equipe técnica na época da Peabiru foi construído ao longo de dois anos de convivência diária. Este é um ponto a ser levantado no que diz respeito não apenas sobre o tempo de permanência dos programas, mas a presença contínua dos técnicos para que a população compreenda a importância do profissional e se aproprie dos conhecimentos do mesmo em benefício próprio.

Esse vínculo foi também construído com os profissionais do Programa Tá Bonito que, de acordo com o presidente da associação de moradores, estavam diariamente no núcleo durante 0 ano em que as obras foram realizadas.

Logo após a conclusão das obras, foi realizada uma pesquisa de satisfação junto aos moradores beneficiados pela primeira el ou segunda fases do Programa Tá Bonito. Por meio de questões objetivas, foram avaliadas as percepções dos entrevistados em relação às melhorias realizadas e ao desenvolvimento do programa (PMD, 2008). 
Numa primeira parte da pesquisa, expressões como arejada, iluminada, maior, mais bonita, mais fácil de limpar, mais segura foram utilizadas para extrair dos morados a sensação de salubridade e de segurança em relação à construção após as reformas. Na média, quase $80 \%$ dos entrevistados responderam estarem satisfeitos em relação a estes aspectos. A PMD atribuiu essa percepção positiva devido à priorização no projeto da execução de aberturas, a instalação de revestimentos cerâmicos, a pintura das paredes, as melhorias nas instalações elétricas, execução de escadas e reforço estrutural (PMD, 2008).

Numa segunda parte da pesquisa, os moradores foram questionados a respeito da qualidade da execução das obras, prazos e problemas enfrentados. Entre os entrevistados, $51 \%$ declararam que a qualidade dos serviços foi regular e ruim e $56 \%$ consideraram o prazo de execução das obras muito longo. Segundo a PMD (2008), essa avaliação ruim foi atribuída à falta de qualificação dos profissionais contratados que não corresponderam às expectativas dos moradores e à demora na entrega dos materiais. A arquiteta entrevistada concorda que seriam necessárias mais horas de formação dos trabalhadores, mas acrescenta que a medida que os trabalhadores foram ganhando experiência durante a realização das intervenções foram pouco a pouco sendo contratados para realizar serviços mais rentáveis e por isso abandonavam as obras.

$\mathrm{Na}$ terceira parte, os moradores avaliaram a qualidade do programa e a relação estabelecida com os técnicos da prefeitura e a associação de moradores. Do total de entrevistados, $49 \%$ declararam não obter por parte da equipe técnica os esclarecimentos necessários às dúvidas durante a obra. Segundo a PMD (2008), existia a necessidade de uma maior aproximação entre os técnicos e moradores. Mesmo assim, 95\% dos entrevistados declararam que o programa deveria continuar.

No geral, todos os moradores entrevistados durante a visita de campo avaliaram o desenvolvimento do programa dentro da comunidade como positivo, pois, segundo eles, melhorou a vida de muitas famílias que não teriam condições de realizar as melhorias de forma independente; também devido ao programa os moradores de todo o núcleo se beneficiaram com a retirada dos lixos e dos entulhos da faixa de domínio da linha de transmissão de alta tensão, o que proporcionou a diminuição da quantidade de ratos no local.

Ainda que tenha tido resultados considerados satisfatórios pela PMD, a segunda fase do Programa Tá Bonito no núcleo Vila Olinda se restringiu a uma experiência isolada. A continuidade do programa ocorreu como preceituada em lei, muito embora se limitando a melhorias das fachadas das unidades residenciais dos núcleos. Apesar de limitada, as intervenções nas fachadas com a 
impermeabilização das mesmas, de acordo com o relatório da PMD (2008) corrigiram problemas de infiltrações e umidades nos ambientes contíguos a elas, o que possibilitou a melhorias na condição de vida das pessoas.

Ao se finalizar o programa, não se concretizou as expectativas iniciais de ampliação do atendimento para outras moradias devido às dificuldades encontradas no percorrer do projeto piloto, conforme exposto pela arquiteta:

Acredito que a experiência da $2^{a}$ fase do Tá Bonito na Vila Olinda não foi replicada em outras
áreas, principalmente devido aos recursos. Como o modelo de composição de recursos
utilizado resultava em alta contrapartida do município (cerca de $50 \%$ ), havia um grande
questionamento, até mesmo dentro da própria secretaria, pois estávamos aplicando recursos
para melhoria interna de unidades consolidadas, enquanto ainda havia famílias morando em
situação de risco no município. Realmente, os recursos necessários para adequar às
moradias a condições mínimas de salubridades são elevados e apesar de termos proposto o
pagamento de uma parte dos investimentos por parte dos moradores, isto não se efetivou
(não por culpa dos moradores, mas da PMD). Talvez se desenvolvêssemos formas efetivas
para garantir o retorno parcial dos investimentos ao FUMAPIS, a sustentabilidade do
programa seria maior. Além disso, as obras de melhoria, principalmente quando envolvem a
parte interna, são dificeis [...] e demoradas, o que dificulta a aplicação em grande escala.
Assim, os resultados atingem uma pequena parcela da população. Outro problema que vejo
é que a gestão do programa nos moldes da $2^{\mathrm{a}}$ Fase do Vila Olinda foi muito difíill. Apesar
da proposta de autogestão, onde a comunidade seria responsável por gerir os recursos, foi
necessário um acompanhamento muito próximo da equipe da prefeitura. Para replicá-lo em
maior escala precisaríamos de uma equipe de apoio muito maior. Acredito que com o tempo,
conforme formos resolvendo os problemas de urbanização e áreas de risco que ainda
persistem no município, haverá mais espaço para o programa de requalificação de unidades.
Já vejo hoje uma receptividade bem maior do que quando iniciamos as discussões da $2^{\mathrm{a}}$
fase em 2006 .

Ao analisarmos a fala da arquiteta percebemos que a desmotivação para a continuidade do programa se deve pela falta de recursos financeiros, pois não se viabilizou uma maneira de retornar 0 investimento realizado pela PMD ao Fumapis, e também pela falta de recursos humanos. Entretanto, ao serem sanados os problemas mais graves de moradia dentro dos núcleos urbanizados, a arquiteta vislumbra um espaço para a discussão junto à prefeitura de um programa de melhorias internas ofertado de maneira continuada.

O projeto não foi ampliado e também não houve um programa de acompanhamento daquelas moradias que sofreram as intervenções, a não ser aquele disponibilizado pela prefeitura para todo 0 município. Uma moradora relatou que assim que as obras foram concluídas era fácil identificar as casas que tinham participado do programa e que, após um tempo, alguns moradores que não haviam participado, também realizaram melhorias nas fachadas das suas casas. Atualmente, as fachadas das moradias atendidas pelo Programa Tá Bonito já evidenciam as novas intervenções empreendidas pelos próprios moradores. A partir da observação externa das 45 moradias atendidas durante a segunda 
fase, em 16 delas foi possível identificar intervenções (Figuras 4 e 5), como a construção de novos pavimentos e cômodos.

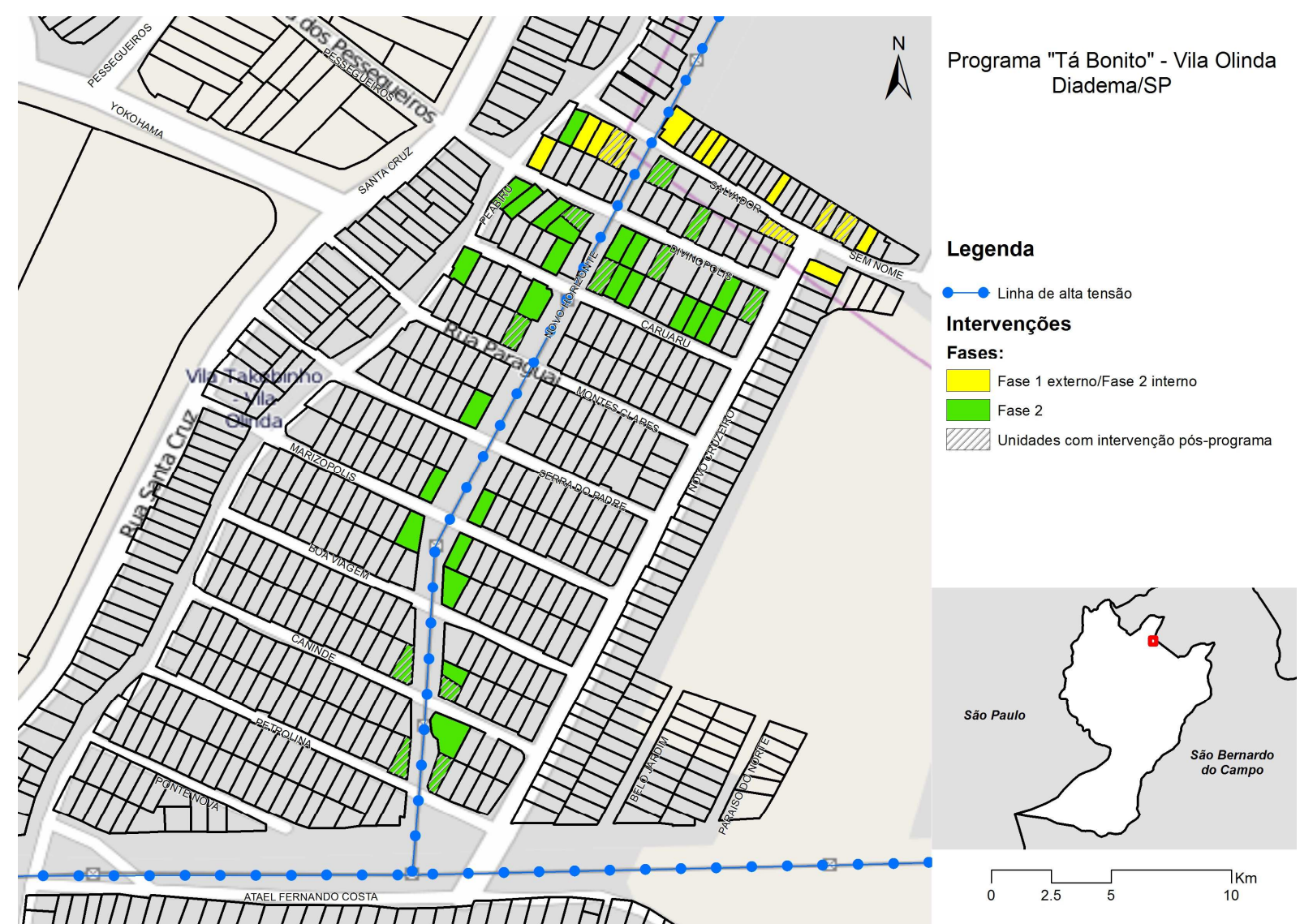

Figura 4. Espacialização das unidades atendidas durante a segunda fase do Programa Tá Bonito onde atualmente é possivel identificar intervenções. Fonte: GOMES, 2014

A necessidade da assistência técnica ocorrer de forma continuada não se restringe à presença do profissional no momento em que o morador vai realizar uma intervenção na construção existente, mas também à orientação e ao auxilio na manutenção do que já foi construído. As patologias possíveis numa edificação não são exclusivas da construção desassistida, ela decorre também pelo uso e pelo desgaste natural dos materiais empregados, por isso seria viável um programa de acompanhamento.

\subsection{Conclusões}

Entre o término da urbanização do Vila Olinda com o programa de assessoria ao autoconstrutor, em 1996, e o início do desenvolvimento do Programa Tá Bonito no núcleo, em 2005, passaram-se quase uma década. Nesse período, vimos que a regularização fundiária dos lotes não havia sido concluída e a associação de moradores, canal importante para dar voz aos anseios da população do núcleo, havia sido desestruturada. Ainda existiam lotes ocupados por barracos de 
madeira e a faixa de domínio da linha de alta tensão da companhia de energia, utilizada como depósito de lixo, não teve destinação adequada ou mesmo aquela intencionada durante a urbanização.

Se analisarmos os dois momentos de iniciativas desenvolvidas dentro do núcleo, o programa de assessoria à autoconstrução durante a urbanização e o Programa Tá Bonito, nota-se que este último foi uma tentativa de retomada do primeiro programa, com a perspectiva da melhoria da condição de vida da população, ao recuperar a assistência técnica neste último momento não mais na construção, mas nas melhorias das moradias consolidadas.

É importante salientar que o Programa Tá Bonito, principalmente no que diz respeito à execução da segunda fase, contribuiu na melhoria das condições de vida das pessoas, como apontado por todos os moradores entrevistados.

A continuidade do programa nos moldes da segunda fase, nas palavras da arquiteta, não ocorreu devido à falta de recursos da PMD, tanto financeiros quanto humanos. A falta de acompanhamento das famílias e das moradias atendidas durante a segunda fase do programa não impediu que fossem realizadas novas intervenções com recursos dos próprios moradores e sem assistência técnica.

Esses dois programas não se trataram apenas de melhorar a condição de vida da população durante um período de tempo, mas abriram a possibilidade da população atendida compreender, se não no todo, mas em parte, o que faz 0 arquiteto $e$, a partir disso, usufruir dos seus serviços, seja para
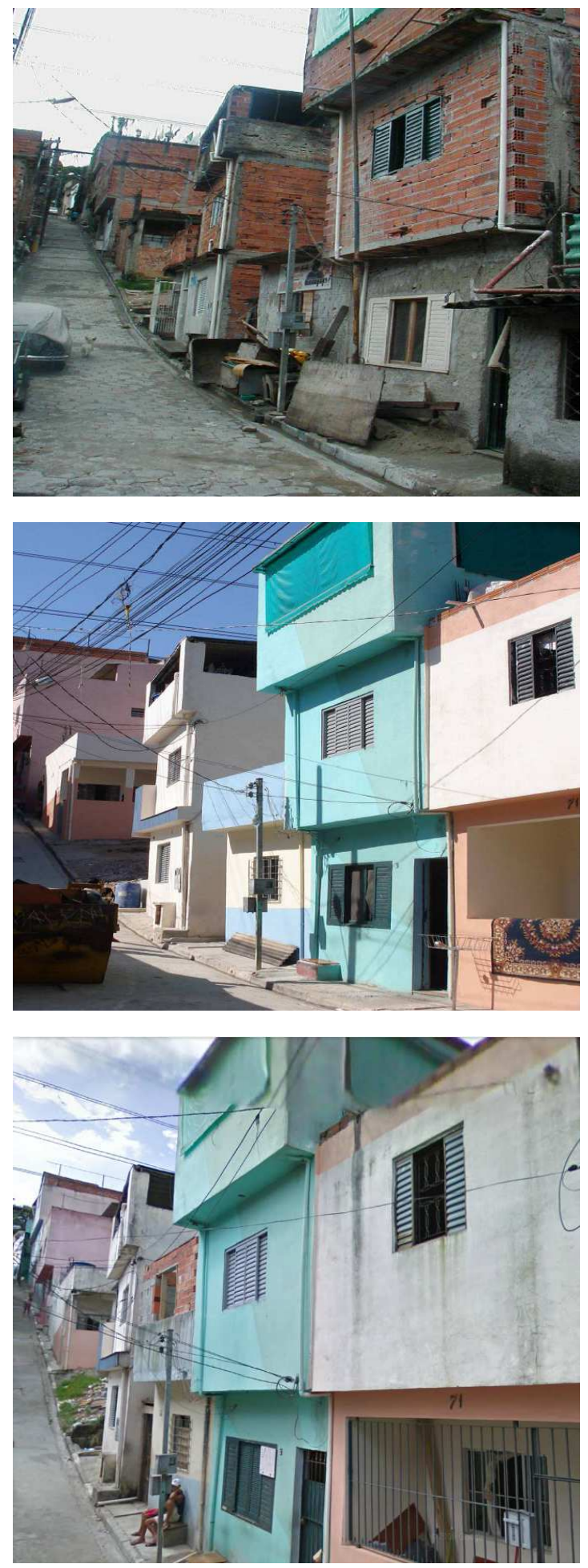

Figura 5. Travessa Salvador. Imagens das casas em três momentos: em 2006 antes das intervenções (a), em 2008 ao término das intervenções (b) e em 2010 com as novas intervenções realizadas pelos moradores (c). Fonte: (a) e (b) PMD, 2008 e (c) Google, fev. 2010. 
sanar uma umidade, ou seja, para propor a reconstrução de uma moradia.

Apesar da arquiteta ter mencionado que existe a oferta de assistência técnica por parte da Secretaria de Habitação de Diadema mais porque a equipe atual se disponibiliza por iniciativa própria a executar esse serviço caso a população recorra a ela do que como uma ação institucional e formal, ainda assim faltam recursos humanos e metodologias específicas para lidar com as particularidades do público que necessita do acesso ao serviço.

$\mathrm{Na}$ Tabela 1 buscamos organizar os apontamentos deste capítulo ao elencar as conquistas e as dificuldades enfrentadas pelo programa, estando ciente que, em muitos dos pontos levantados, tais dificuldades não se restringem aos problemas de execução do mesmo, mas perpassam por discussões intrínsecas ao papel social do arquiteto na sociedade brasileira.

Tabela 1. Dificuldades e conquistas do Programa Tá Bonito.

\begin{tabular}{|c|c|c|}
\hline $\begin{array}{l}\text { Aspectos } \\
\text { analisados }\end{array}$ & Dificuldades & Conquistas \\
\hline $\begin{array}{l}\text { 1) Estratégias } \\
\text { de divulgação e } \\
\text { acesso ao } \\
\text { serviço }\end{array}$ & $\begin{array}{l}\text { - Ainda que haja uma disponibilidade dos } \\
\text { técnicos em assessorar a elaboração do } \\
\text { projeto da população participante ou não do } \\
\text { programa, como não existe uma estrutura } \\
\text { exclusiva para a assistência técnica, podemos } \\
\text { dizer que o acesso também é restrito e } \\
\text { fracamente institucionalizado. } \\
\text { - A falta de recursos financeiros e humanos que } \\
\text { impediu a continuidade do programa. }\end{array}$ & $\begin{array}{l}\text { - O empenho dos técnicos em elaborar a } \\
\text { segunda fase do programa que contemplou } \\
\text { a melhoria interna das unidades } \\
\text { habitacionais. } \\
\text { - Construção do programa junto com os } \\
\text { moradores. }\end{array}$ \\
\hline $\begin{array}{l}\text { 2) Aproximação } \\
\text { do arquiteto } \\
\text { junto à } \\
\text { população }\end{array}$ & $\begin{array}{l}\text { - Visão do arquiteto culturalmente associada ao } \\
\text { profissional que atende as classes de maior } \\
\text { renda; } \\
\text { - Desconhecimento do papel do arquiteto dentro } \\
\text { da prática da autoconstrução. } \\
\text { - Visão do arquiteto como um agente fiscal que } \\
\text { irá impor os parâmetros e as regras de } \\
\text { ocupação do solo; e } \\
\text { - Falta de credibilidade inicial no programa. }\end{array}$ & $\begin{array}{l}\text { - A permanência dos técnicos do programa } \\
\text { diariamente durante o período de obras } \\
\text { permitiu com que fossem estabelecidos } \\
\text { vínculos importantes com a população, } \\
\text { moradores e mão de obra. }\end{array}$ \\
\hline
\end{tabular}




\begin{tabular}{|c|c|c|}
\hline $\begin{array}{l}\text { 3) Elaboração } \\
\text { do projeto } \\
\text { personalizado }\end{array}$ & $\begin{array}{l}\text { - Ao se utilizar apenas da linguagem tradicional } \\
\text { da arquitetura (plantas, cortes e fachadas), } \\
\text { compromete-se a apropriação do projeto pelo } \\
\text { morador dificultando a aceitação das } \\
\text { propostas de intervenção e a negociação } \\
\text { daquilo que é prioridade diante dos recursos } \\
\text { disponíveis. } \\
\text { - A ocupação da área total do lote pelas } \\
\text { construçães, originada no momento da } \\
\text { urbanização do núcleo, dificulta sanar } \\
\text { problemas de umidade e de infiltração e } \\
\text { compromete a ventilação e a iluminação dos } \\
\text { cômodos. } \\
\text { - Dificuldade em se formular medidas para } \\
\text { correção das patologias construtivas dentro do } \\
\text { contexto da autoconstrução que perpassa a } \\
\text { unidade isolada. }\end{array}$ & $\begin{array}{l}\text { - Pela dificuldade apresentada pelos } \\
\text { moradores em compreender as propostas } \\
\text { elaboradas pelos profissionais, a equipe } \\
\text { técnica do programa propôs outra forma } \\
\text { de apresentação em outra comunidade, } \\
\text { como a maquete; } \\
\text { - Contato permanente com a mão de obra } \\
\text { para sanar possíveis dúvidas durante a } \\
\text { realização das obras }\end{array}$ \\
\hline $\begin{array}{l}\text { 4) Resultados e } \\
\text { limitações }\end{array}$ & $\begin{array}{l}\text { - A falta de pós-acompanhamento das moradias } \\
\text { atendidas pelo programa faz com que } \\
\text { patologias decorrentes dos desgastes naturais } \\
\text { dos materiais empregados recriem ambientes } \\
\text { insalubres e, no limite, mostrem a ineficácia do } \\
\text { programa e consequente descrédito da } \\
\text { população por esse tipo de programa e } \\
\text { profissional; } \\
\text { - A mão de obra desqualificada, as intervenções } \\
\text { em construções precárias, a topografia } \\
\text { acidentada dos lotes, as vielas estreitas e a } \\
\text { necessidade de remoção das famílias para a } \\
\text { realização das obras causaram atraso no } \\
\text { cronograma físico e o aumento do custo } \\
\text { previsto no cronograma financeiro; } \\
\text { - o período de um ano decorrido entre o início } \\
\text { do programa dentro da comunidade e a } \\
\text { liberação do início das obras, bem como a falta } \\
\text { de compreensão por parte dos moradores da } \\
\text { importância de se cumprir o contrato assinado } \\
\text { junto à CEF, fez com que alguns serviços } \\
\text { previstos em projeto fossem realizados pelos } \\
\text { moradores sem qualquer acompanhamento; } \\
\text { - Dificuldade da associação de moradores em } \\
\text { gerenciar os recursos, a contratação da mão } \\
\text { de obra e a compra do material de construção; } \\
\text { - Pela observação empírica, algumas moradias } \\
\text { sofreram interferências após a finalização do } \\
\text { programa, o que sugere que a assistência } \\
\text { técnica não precisa necessariamente estar } \\
\text { vinculada ao financiamento ou ao subsídio da } \\
\text { compra do material de construção. Esta } \\
\text { observação é passivel de maiores estudos e } \\
\text { análises; }\end{array}$ & $\begin{array}{l}\text { - Capacidade dos técnicos em lidar com as } \\
\text { dificuldades durante o desenvolvimento do } \\
\text { programa ao rever os projetos, os } \\
\text { cronogramas físicos e financeiros e a } \\
\text { logística das obras; } \\
\text { - Revisão da forma de contratação da mão } \\
\text { de obra (remuneração que era mensal } \\
\text { passou a ser por produtividade); } \\
\text { - Para se adequar as exigências da CEF a } \\
\text { prefeitura substituiu o Habite-se por um } \\
\text { atestado de habitabilidade; } \\
\text { - Reestruturação jurídica da associação de } \\
\text { moradores para atender às exigências da } \\
\text { CEF para repasse dos recursos } \\
\text { financeiros. }\end{array}$ \\
\hline
\end{tabular}


Desmitificar 0 arquiteto e aproximá-lo dos moradores é condição ímpar para que juntos, arquiteto e morador, consigam equacionar os problemas e, a partir disso, apontarem as soluções viáveis. Soluções essas que devem considerar o contexto da relação do morador com a casa e 0 respeito aos recursos financeiros e humanos empenhados ao longo dos anos.

Sem esse trabalho de aproximação, continuará sendo recorrente a rejeição da população em relação à orientação técnica, pois, como relatou a arquiteta sobre a sua prática profissional, os moradores se consideram aptos a solucionarem sozinhos as suas necessidades habitacionais.

Incorporar a favela à cidade não diz respeito apenas ao parcelamento do solo, aos instrumentos que garantam a posse da terra, à instalação de infraestrutura que minimamente atenda aos moradores. Diz respeito também à percepção do morador em relação ao lugar que habita exatamente por ele ser o foco das intervenções.

A seguir apresentaremos a experiência em assistência técnica de Cuba, desenvolvida na Província de Holguin, com o trabalho dos Arquitetos da Comunidade. 


\section{O caso de Cuba - Os Arquitetos da Comunidade}

Neste capítulo abordaremos o programa de assistência técnica denominado Arquitetos da Comunidade desenvolvido em Cuba, desde 1994, mais especificamente o da província de Holguín ${ }^{30}$. Incorporado em 1998 ao Instituto Nacional de Habitação, o programa está atualmente representado nas 15 províncias do país e na llha da Juventude ${ }^{31}$.

Vale salientar que o conceito de assistência técnica individualizada existia no país desde a Lei de Habitação de 1988, a qual instituiu a obrigatoriedade da contratação do serviço por todas as pessoas que desejassem construir uma nova moradia ou intervir na moradia existente. Apesar de assegurado em lei, naquele momento, ainda não havia uma estrutura consolidada que garantisse 0 atendimento dessa demanda. É para preencher esse vazio que por iniciativa de arquitetos e de engenheiros surge o Programa Arquitetos da Comunidade.

A escolha em estudar o programa Arquitetos da Comunidade foi motivada pela metodologia de trabalho adotada por esses profissionais que, diante do contexto de crise econômica iniciada em 1989, criaram instrumentos para o oferecimento de assistência técnica em ampla escala de atuação, sem perder a perspectiva do projeto participativo e personalizado. Nos quatro primeiros anos de atuação do

\footnotetext{
${ }^{30}$ Atualmente, Holguín é a terceira província mais populosa de Cuba.

${ }^{31}$ Atualmente, Cuba está dividida em 15 províncias e a llha da Juventude. Cada província está dividida em municípios.
} 
grupo, ou seja, antes mesmo de estar sob a responsabilidade do Estado, já tinham sido realizados mais de 180 mil atendimentos em todo o país (RABINOVICH, 2007).

A partir da análise da atuação dos Arquitetos da Comunidade, buscaremos responder três perguntas: a) como os arquitetos se aproximam da população; b) como são realizados os projetos a partir do atendimento personalizado; e c) como ganham escala de atuação. Partimos da hipótese de que a ampla divulgação e a facilidade de acesso ao serviço proporciona a procura recorrente destes profissionais pela população.

Para discutirmos o programa cubano fizemos uso de bibliografias a respeito da política habitacional do país, bem como de entrevistas com integrantes do grupo da cidade de Holguín, entre eles Ricardo Martinez, economista e especialista em gestão de recursos humanos; Danis Vásquez e Laritza Miguel, ambas arquitetas fundadoras do programa e Mestres em Habitação Social e Yaqueline ${ }^{32}$, também arquiteta. As três arquitetas ocupam o cargo de especialistas em manutenção e reabilitação. Também acompanhamos in loco as visitas técnicas das arquitetas no período de 18 a 20 de setembro de 2012 e utilizamos registro pessoal em diário de campo.

O presente texto está dividido em duas partes. A primeira apresenta uma breve discussão a respeito da problemática habitacional de Cuba e das soluções adotadas e a segunda analisa a atuação dos Arquitetos da Comunidade de Holguín.

\subsection{A política habitacional de Cuba}

Para abordar a problemática habitacional de Cuba, é necessário contextualizá-la a luz da especificidade desse país, pois aos desafios comuns dessa problemática aos países em desenvolvimento se adicionam novos decorrentes do contexto geopolítico e de seus desdobramentos sobre o processo de desenvolvimento cubano.

Em 1958, a população do país era de quase seis milhões de habitantes, sendo que aproximadamente $60 \%$ residiam na área urbana do país (ONE, 2007) e os moradores das favelas e dos assentamentos informais correspondiam a quase um terço da população (DAVIS, 2006). Somado

\footnotetext{
${ }^{32}$ Até a conclusão da presente pesquisa não conseguimos o nome completo de Yaqueline.
} 
a isso, boa parte da população tinha gastos excessivos com o aluguel. Em 1953, essa população correspondia a mais de dois milhões de habitantes (CASTRO RUZ, 2007)33.

Segundo o sociólogo Florestan Fernandes (2012), até 0 ano de 1959, as péssimas condições de vida do povo cubano, em decorrência da miséria, da fome e da corrupção sustentadas pelo domínio dos Estados Unidos na produção de açúcar de Cuba, desencadearam uma revolução de apoio popular embasada pelo ideário coletivo de nação.

O governo que assumiu o país, como parte da política de erradicação da pobreza e da melhoria da condição de vida da população, reconheceu o direito de todos os cidadãos à moradia adequada (Figura 6) ao considerar esse um dos aspectos necessários para a garantia da saúde, da segurança e do bem-estar geral da população (CEPAL, PNUD, INIE, 2004). Para se efetivar o direito à moradia, foi promulgada a Lei da Reforma Urbana de 1984, a qual estabeleceu que os ocupantes se tornassem proprietários das casas onde viviam (MORAIS, 2010).

Rabinovich $(2010)^{34}$, ao analisar o papel atribuído à população nas políticas habitacionais de Cuba desde 1959, apontou que nos primeiros quatro anos após a revolução (1959 - 1963), a fim de erradicar

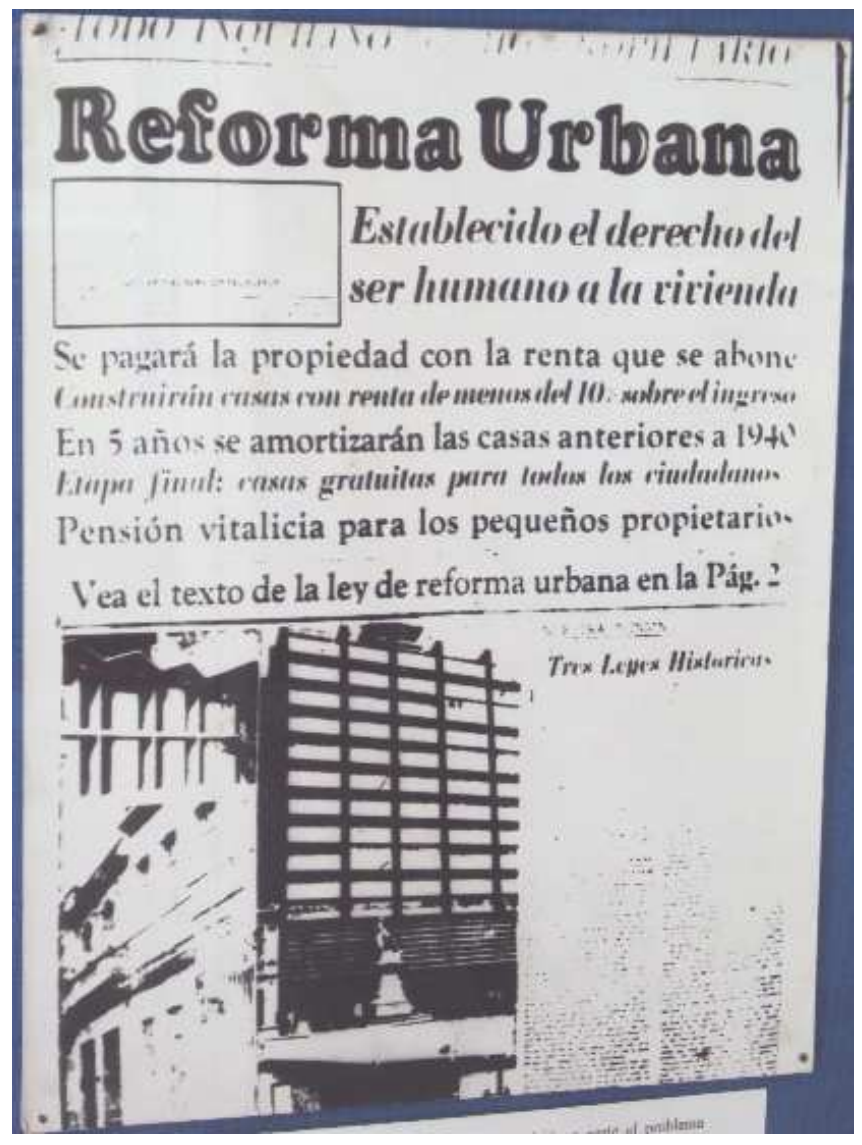

Figura 6. Propaganda que divulgava a reforma urbana, um dos ícones do governo de Fidel Castro. Imagem exposta no Museu da Revolução. Fonte: GOMES, 2012. as situações habitacionais precárias, 0

Estado promoveu a construção de 85 mil unidades habitacionais, das quais dois terços foram realizadas sob a orientação técnica do Ministério de Obras Públicas com mão de obra da população35.

\footnotetext{
${ }^{33}$ Discurso de defesa proferido por Fidel Castro em 1953 durante o julgamento do assalto ao quartel general de Moncada.

34 Adriana Rabinovich é pesquisadora do Centro Norte-Sul (Desenvolvimento Sustentável) da Universidade de Berna, Suíça.

${ }^{35}$ De acordo com a autora, essa solução foi de curta duração devido à irregularidade da produção e à mão de obra pouco qualificada.
} 
O outro terço foi realizado por meio da produção privada e, desse total, aproximadamente a metade foi autoconstruída sem qualquer tipo de orientação técnica (RABINOVICH, 2010).

A partir de 1965, o investimento estatal foi direcionado para a construção de novas unidades em grandes conjuntos habitacionais (Figura 7). Entretanto, Perez $(1993)^{36}$ assinalou que as iniciativas individuais de produção de moradia em Cuba foi mais eficiente, em termos quantitativos, que a produção estatal, uma vez que, entre 1959 e 1990, enquanto o estado construiu 495 mil unidades habitacionais ${ }^{37}$, a

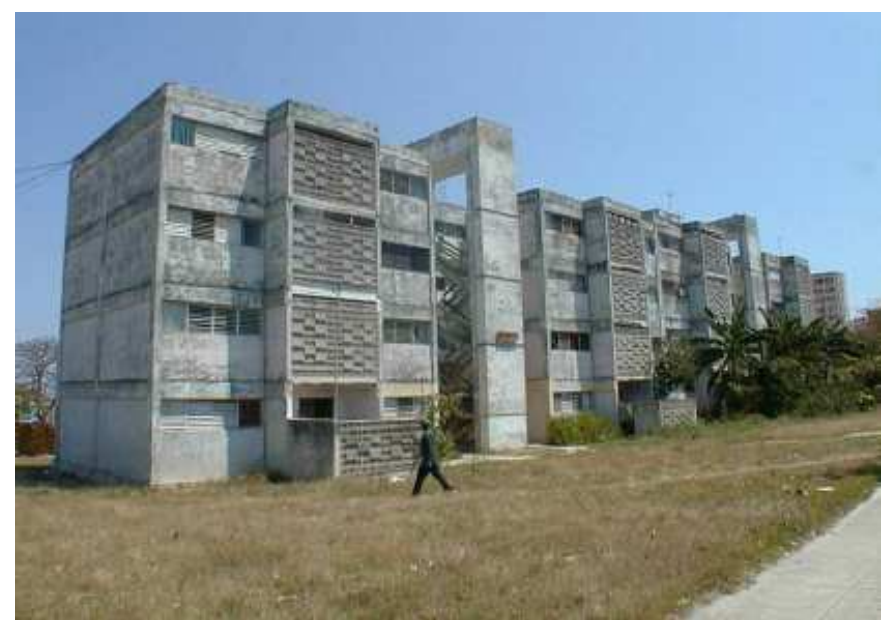

Figura 7. Exemplo de conjunto habitacional executado pelo Estado com elementos pré-fabricados. Fonte: Millán e Coto, 2010. autoconstrução foi responsável pela produção de 1,33 milhões de unidades ${ }^{38}$. Segundo a autora, do total de moradias realizadas pela população nesse período, $51 \%$ não tinham registro no cartório de imóveis e o restante encontrava-se parcialmente registrado.

Como estratégias de assegurar os programas sociais e econômicos do país, o Estado priorizou apenas o enfrentamento do déficit habitacional quantitativo (CEPAL, PNUD, INIE, 2004). De acordo com Mesa-Lago (2005) ${ }^{39}$, entre 1981 e 1989, a produção anual de habitação no país foi de 61 mil novas unidades.

A primeira Lei de Habitação em 1984 legalizou a transferência da moradia aos seus ocupantes. De acordo com Coyula (2006) ${ }^{40}$, essa ação afetou $85 \%$ da população. 0 autor aponta que se por um lado as pessoas que residiam em moradias de boa qualidade construtiva e bem localizadas foram beneficiadas, por outro lado, parte da população ficou vinculada a moradias mal edificadas, com problemas estruturais e que não atendiam de forma satisfatória as necessidades dos moradores. $A$

\footnotetext{
${ }^{36}$ Mayda Perez Alvarez é arquiteta cubana.

${ }^{37}$ A construção pelo Estado das unidades habitacionais era realizada por meio das empresas estatais e das microbrigadas. De acordo com Rabinovich (2010), as microbrigadas consistiam no fornecimento de terreno, de materiais de construção e de assistência técnica pelo Estado com a utilização da mão de obra de grupos que agregavam 33 trabalhadores, deslocados de seus centros de trabalho, e que recebiam capacitação para a realização das construções. De acordo com Morais (2010), em 1970, havia três microbrigadas no país e, no final do ano de 1974, elas correspondiam a 1.125.

${ }^{38}$ Moradias construídas para incremento e reposição do estoque habitacional.

${ }^{39}$ Carmelo Mesa-Lago é professor emérito de Economia da Universidade de Pittsburgh.

${ }^{40}$ Mario Coyula é arquiteto e professor emérito da Faculdade de Arquitetura da Universidade de Cuba (CUJAE).
} 
partir de então, as pessoas se viram obrigadas a arcar com a manutenção e a reparação das suas casas utilizando-se de recursos próprios e sem o apoio das empresas estatais designadas para realizar tais serviços, pois estas não estavam estruturadas adequadamente para atender a demanda acumulada até o momento (COYULA, 2006).

A Lei de Habitação de 1988 apontou que as iniciativas individuais de construção ou de melhoria das moradias (ampliação, divisão, unificação) deveriam ser acompanhadas por assistência técnica e projeto, a serem contratados pelo morador ${ }^{41}$. Segundo a lei, o crédito para a compra do material de construção, o pagamento dos serviços de assistência técnica, assim como os outros serviços técnico-construtivos necessários poderia ser financiado junto ao Banco de Poupança Popular.

A crise iniciada em 1990 com a dissolução da União Soviética que reduziu drasticamente a produção de materiais de construção, somada a continuidade do forte embargo econômico e a Lei de Habitação de 1988 que, de acordo com Mesa-Lago (2005), fortaleceu o papel do Estado na produção habitacional a partir da restrição da compra de materiais de construção diretamente pelo cidadão, resultaram na queda do número de moradias autopromovidas pela população. Durante os anos de 1980, a autoprodução da moradia pela população correspondeu a $60 \%$ do total de habitação produzida no país, enquanto na década seguinte, essa porcentagem não ultrapassou $34 \%$ do total de unidades edificadas (MESA-LAGO, 2005).

A dependência de Cuba em relação às tecnologias e aos investimentos externos, durante a crise econômica, afetou o setor da construção civil. A produção de cimento que, em 1989, era de aproximadamente quatro milhões de toneladas, em 1993, caiu para um milhão de toneladas (CEPAL, PNUD, INIE, 2004).

Em 1992, foram lançadas como ações estratégicas para o enfrentamento da crise: o emprego de técnicas de baixo consumo para construção de novas unidades habitacionais; o desenvolvimento de materiais de construção utilizando matérias primas locais; a prioridade nas ações de conservação, de manutenção e de melhoria do estoque habitacional existente; e o aumento da participação da população na solução dos problemas habitacionais (CEPAL, PNUD, INIE, 2004).

\footnotetext{
${ }^{41}$ A prestação de serviço de arquitetura de forma autônoma não é permitida no país. Portanto, a assistência técnica que trata a Lei de Habitação de 1988 é aquela prestada por entidades do governo, como o Ministério da Construção ou entidades autorizadas por aquele. A assistência técnica ainda poderia ser prestada gratuitamente por um familiar do morador.
} 
Em 2012, segundo dados preliminares do último censo, Cuba registrou mais de três milhões e 700 mil domicílios ocupados e uma população de aproximadamente 11 milhões e 100 mil habitantes e desse total, $77 \%$ residiam na área urbana do país (ONE, 2012). De acordo com o governo cubano, estimava-se que em 2013 o déficit habitacional do país era de 600 mil novas unidades residenciais (RAVSBERG, 2013).

De acordo com o Ministério da Construção (2011), entre 2001 e 2008, a passagem de dez furacões de grande intensidade pelo país afetou mais de um milhão e 500 mil unidades habitacionais e $12 \%$ do total foram destruídas. Até junho de 2010 , do total de domicílios existentes no país, quase 800 mil necessitavam de ações de reparos e, aproximadamente, 520 mil unidades careciam de ações de melhorias ou mesmo de serem repostas (MINISTÉRIO DA CONSTRUÇÃO, 2011).

Em 2012, a renda média do trabalhador cubano empregado nas empresas estatais e nas empresas mistas era de 466 pesos cubanos (ONE, 2012). Enquanto os serviços de utilidade pública tirar esta vírgula como o transporte, cujo valor de uma viagem de ônibus corresponde $0,02 \%$ da renda média do trabalhador, a aquisição de um saco de cimento compromete $32 \% 42$ dessa mesma renda. Portanto, se por um lado os serviços se tornam acessíveis, o alcance aos produtos industrializados é custoso. É por isso que no país presenciamos uma necessidade constante de conservar, de reformar e de adaptar as construções existentes às novas necessidades, principalmente as moradias que precisam se adequar aos novos arranjos familiares.

Os Arquitetos da Comunidade foram criados dentro de um contexto no qual o planejamento da construção e o emprego correto dos recursos materiais são condicionantes para efetivar o direito da população à moradia adequada. A seguir abordaremos as conquistas e as limitações desse programa.

\subsection{O Programa Arquitetos da Comunidade}

Em 1994, diante do contexto de crise econômica e da consequente diminuição das ações governamentais nos programas habitacionais, foi criado de forma independente da estrutura do governo o Programa Arquitetos da Comunidade. Iniciativa da Organização Não Governamental (ONG) Habitat Cuba, o grupo buscou oferecer a assistência técnica à população nos projetos de construção nova, de reabilitação e de melhoria de unidades existentes.

\footnotetext{
${ }^{42}$ Em 2012, a passagem de ônibus na cidade de Holguín custava 10 centavos de peso e o saco de cimento de 50kg equivalia a 150 pesos cubanos.
} 
O primeiro escritório dos Arquitetos da Comunidade foi inaugurado na cidade de Holguín, em 1994, com a participação de 14 arquitetos. Capital da província que leva o mesmo nome, Holguín está distante aproximadamente $750 \mathrm{~km}$ de Havana, capital do país. A província de Holguín possuía, em 2012, mais de 331 mil unidades habitacionais.

A partir da fundação, o programa Arquitetos da Comunidade passou a atuar em todo o território nacional nas cidades com mais de 10 mil habitantes residentes em área urbana, com o objetivo específico de oferecer à população os serviços técnicos profissionais para a melhoria das condições construtivas das unidades habitacionais ao priorizar o projeto participativo.

Em 1998, os Arquitetos da Comunidade foram incorporados ao Instituto Nacional de Habitação e se tornaram um programa do Estado ao responder por diversos serviços técnicos, além da elaboração dos projetos. Apesar de ter sido incorporado a política habitacional nacional, permaneceu financeiramente independente do apoio governamental por ser um programa autossustentável. Em 2010, os Arquitetos da Comunidade contabilizavam 1.064 profissionais entre arquitetos e engenheiros distribuídos por todo o país, conforme Figura 8.

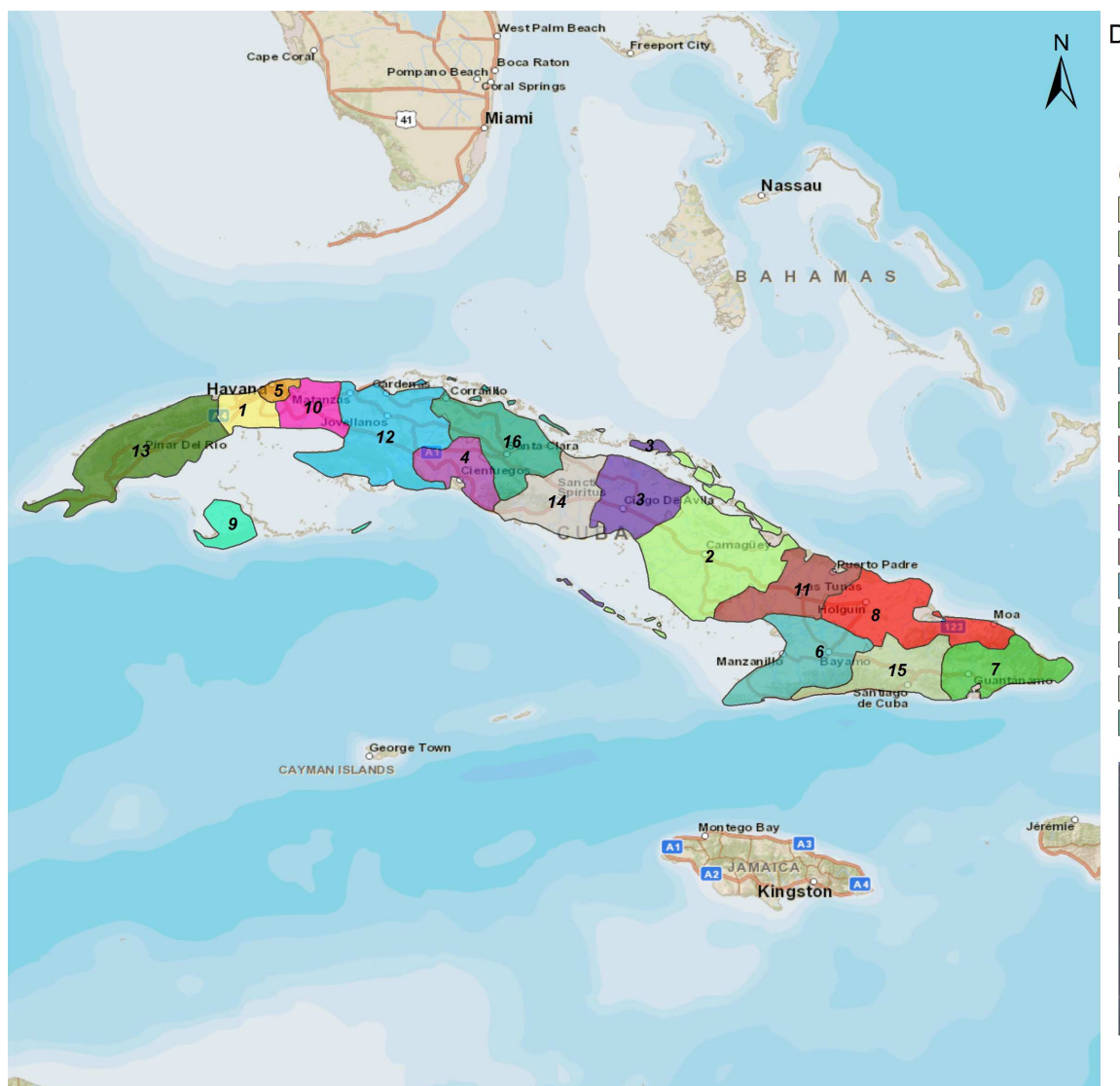

Divisão administrativa das províncias de Cuba e número de arquitetos e engenheiros presentes

Cuba - Províncias

1 - Artemisa: sem dados

2 - Camaguey: 56 profissionais

3 - Ciego de Avila: 49 profissionais

4 - Cienfuegos: 92 profissionais

5 - Ciudad de la Habana: 228 profissionais

6 - Granma: 92 profissionais

7 - Guantanamo: 34 profissionais

8 - Holguin: 61 profissionais

9 - Isla de la Juventud: 18 profissionais

10 - La Habana: 54 profissionais

11 - Las Tunas: 56 profissionais

12 - Matanzas: 72 profissionais

13 - Pinar del Rio: 62 profissionais

14 - Sancti Spiritus: 59 profissionais

15 - Santiago de Cuba: 54 profissionais

16 - Villa Clara: 77 profissionais

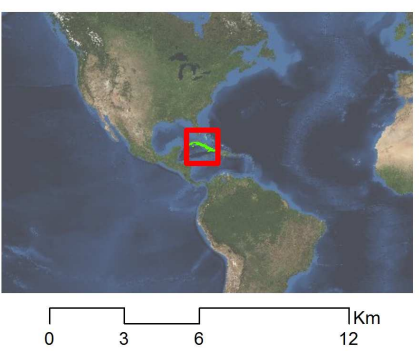

Figura 8. Número de profissionais distribuídos por província. Fonte: Millán e Coto, 2010. 
Atualmente, para todos os trâmites que envolvam o imóvel o morador deve solicitar uma licença junto à secretaria de habitação municipal e contratar uma entidade de prestação de serviços de assistência técnica. Esse processo é necessário tanto para as intervenções simples, como para as pinturas das fachadas, a construção de cisternas e de muros de divisa ou para as obras mais complexas, que necessitam da elaboração de projetos como novas construções, ampliações, remodelações, divisão da moradia, desenho de interiores, desenho de mobiliário, desenho de áreas externas e de jardins e modificações nas fachadas. Pareceres técnicos de um arquiteto ou de um engenheiro também são solicitados nos casos de permutas ${ }^{43}$ de moradias, de divisão e de unificação de imóveis, de doações, de disputas judiciais, de omissões e de correções de escrituras, de atestados sobre o estado construtivo do imóvel, de arrendamentos e de atestados de conclusão de obra.

\subsection{Divulgação e acesso aos serviços}

Na província de Holguín, de acordo com Ricardo Martinez, para a divulgação dos serviços junto à população foi criado um programa em um canal de televisão local ${ }^{44}$ chamado 'Pergunte a um Especialista'. Este programa tinha a duração de 30 minutos e divulgava os serviços dos Arquitetos da Comunidade ao responder as dúvidas dos telespectadores a respeito de problemas construtivos e de trâmites legais envolvendo a moradia.

Danis Vásquez explicou que o primeiro contato com a família a ser atendida é realizado na sede da prefeitura do município. Nesse dia, os moradores junto com o profissional preenchem 0 requerimento de atendimento e agendam a visita com 0 arquiteto responsável pela região onde está localizada a moradia. Cada município é dividido em áreas de atuação e os arquitetos, distribuídos em duplas, ficam responsáveis pelo atendimento ao público dessas regiões da cidade em dia da semana pré-estabelecido. Apesar de estarem divididos em regiões, os arquitetos podem ser solicitados pelos moradores de regiões que não fazem parte da sua área de atuação, visto que alguns moradores buscam arquitetos indicados por familiares ou por conhecidos devido à confiança que estabeleceram durante a realização de trabalhos anteriores.

Ainda de acordo com Danis Vasquez, na cidade de Holguín existem quatro escritórios do governo para 0 atendimento da população pelos profissionais. Existem também dois escritórios dos

\footnotetext{
${ }^{43}$ Como a compra e a venda da unidade habitacional era proibida até o final do ano de 2011, a permuta de residências ainda é uma prática comum.

${ }^{44}$ Canal da Província de Holguín chamado Tele Cristal.
} 
Arquitetos da Comunidade que são utilizados para fins administrativos, além de servirem como locais de reuniões para se discutirem entre os pares semanalmente os casos que suscitam dúvidas ${ }^{45}$ (Figura 9).

Todos os serviços são cobrados diretamente da população atendida e sem subsídio do governo ${ }^{46}$. Uma das estratégias do programa para permitir o acesso facilitado pela população foi o tabelamento de valores a serem cobrados pelos atendimentos em todo 0 país, a partir da uniformização dos serviços prestados.

Podem-se dividir as etapas da prestação do serviço em três partes: 0 levantamento da situação existente, a elaboração do projeto e a retificação dos documentos legais.

O valor a ser pago depende da área da moradia. Para o levantamento da situação existente e para a elaboração do projeto são

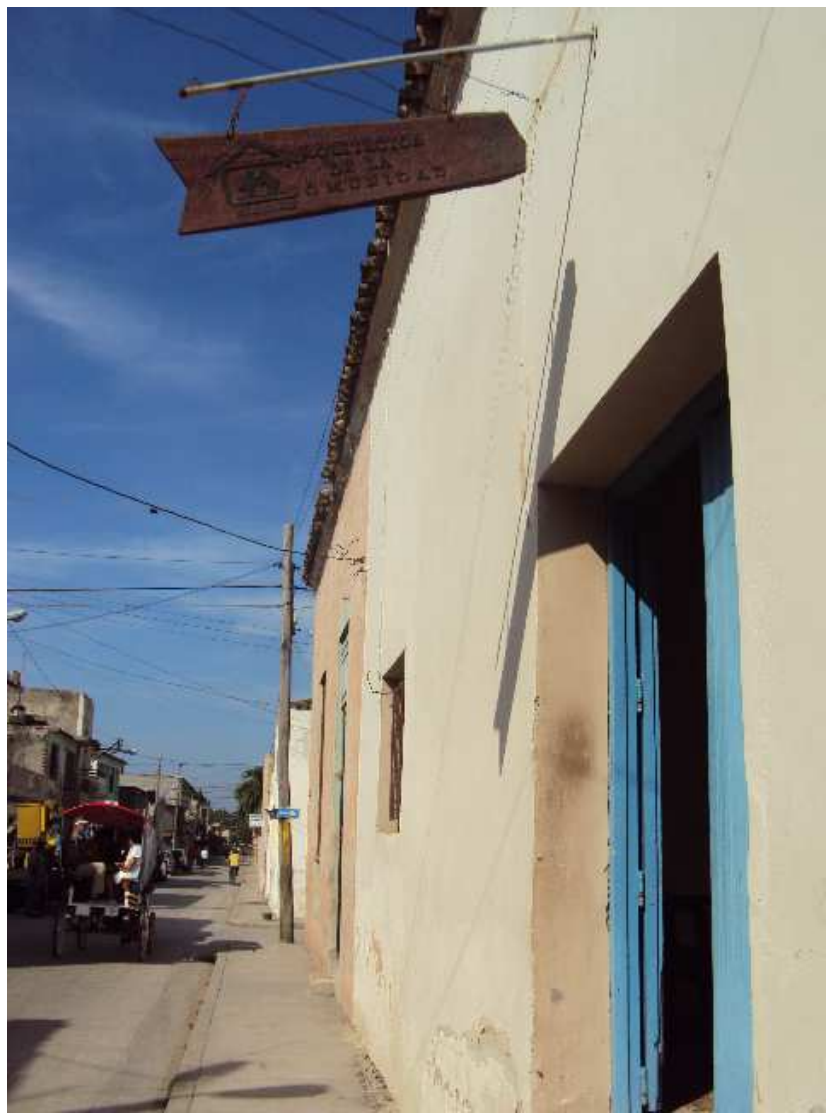

Figura 9. Vista da entrada de um dos escritórios dos Arquitetos da Comunidade na cidade de Holguín. Fonte: GOMES, 2012 cobrados o mesmo valor, sendo escalonados da seguinte forma: até $60 \mathrm{~m}^{2}$ de área construída são cobrados 40 pesos cubanos, entre $60 \mathrm{~m}^{2}$ e $80 \mathrm{~m}^{2}$ são cobrados 60 pesos cubanos, acima de $80 \mathrm{~m}^{2}$ são cobrados 80 pesos cubanos. Para a realização da retificação dos títulos de propriedade são cobrados 30 pesos cubanos. Se tomarmos como exemplo a elaboração de um projeto de melhorias para uma residência com $60 \mathrm{~m}^{2}$, o proprietário pagaria pelos

\footnotetext{
${ }^{45}$ Ainda que o agendamento seja realizado na sede da prefeitura, a existência de escritórios dos Arquitetos da Comunidade reforça o caráter independente do programa.

${ }^{46}$ A população que perdeu suas casas em virtude de desastres naturais tem direito a um projeto com $25 \mathrm{~m}^{2}$ de construção subsidiados integralmente pelo Estado. Nesses casos, o Estado outorga um subsídio para a contratação de projeto e de execução da construção. A moradia é construída pelas brigadas especializadas pagas pelo Estado com a ajuda do morador e são realizadas em blocos de concreto composta por um dormitório, cozinha e banheiro.
} 
serviços técnicos o total de 110 pesos $^{47}$. 0 valor máximo para a elaboração de um projeto de nova construção ou ampliação é de 240 pesos $^{48}$.

Em relação à renda média mensal do trabalhador cubano, o valor do projeto pelo exemplo proposto corresponde a $23,6 \%$ do salário. Vale salientar que a renda média não é, necessariamente, a renda familiar e, portanto, essa proporção pode ser menor se considerarmos as remunerações de todos os membros da família 49 .

Os valores são pagos na realização de cada etapa do serviço prestado. Os profissionais têm $72 \mathrm{~h}$ para depositar o pagamento recebido pelo trabalho contratado em uma conta do governo. $\mathrm{O}$ salário dos especialistas é calculado a partir de um salário base e acrescido de uma porcentagem que varia de acordo com o tempo de experiência do profissional. Soma-se a isso outra porcentagem em relação ao valor e ao tipo de projetos realizados e a natureza do contratante, se a população ou o Estado, sendo que o valor pode variar entre $20 \%$ a $50 \%$ do custo do projeto.

A partir do levantamento da situação existente, o profissional tem 60 dias para apresentar 0 projeto. Caso ele não cumpra com o prazo, sofre uma penalidade, como advertências e descontos nos salários.

O Estado pode financiar a compra do material de construção por meio de crédito concedido às pessoas com baixa capacidade financeira e a execução da obra é autopromovida pelas famílias, sem ajuda estatal.

\subsection{Perfil dos arquitetos}

Os profissionais que trabalham no programa assumem o cargo de Especialistas em Conservação e Reabilitação. Esse cargo atribuído pelo Ministério da Construção, órgão que qualifica e

\footnotetext{
${ }^{47}$ Esse valor é composto por 40 pesos relativos ao levantamento +40 pesos para a elaboração do projeto +30 pesos pela correção do título de propriedade.

48 Para os casos que não envolvem a elaboração de projeto, como nos casos de correção das descrições do imóvel constante nos títulos de propriedade, o valor cobrado para a realização do desenho que subsidia a descrição varia de acordo com o número de pavimentos do imóvel. Para uma casa com um pavimento cobra-se 30 pesos cubanos, caso sejam dois pavimentos são 45 pesos. Pela retificação do texto da descrição do imóvel no título de propriedade são cobrados 30 pesos.

${ }^{49}$ No Brasil, pela tabela de honorários estabelecida pelo Conselho de Arquitetura e Urbanismo (CAU), o preço da venda do projeto considera a área construída, o custo do $\mathrm{m}^{2}$ da construção e a tipologia da edificação. Se considerarmos um projeto de interesse social com área a ser construída de $60 \mathrm{~m}^{2}$, o preço da venda do projeto será de $R \$ 2.733,75$, o que equivale a 3,78 vezes o valor do salário mínimo. O valor do salário mínimo em janeiro de 2014 corresponde a $R \$ 724,00$.
} 
classifica os profissionais de acordo com as atribuições de cada função, estabelece o salário a ser pago igualmente em todo o país. 0 cargo de especialista em conservação e reabilitação pode ser preenchido por um arquiteto, um engenheiro civil, um engenheiro estrutural ou por outro título universitário, desde que atenda ao perfil requerido.

Na cidade de Holguín trabalham 26 profissionais, sendo 21 arquitetos e cinco engenheiros. Quando os profissionais terminam a graduação, recebem um treinamento durante dois anos na área de atuação escolhida sob a supervisão de um especialista mais experiente. Na verdade, para assumir qualquer cargo é necessário receber esse treinamento.

A seleção dos profissionais ocorre a partir de uma convocatória. Os profissionais interessados pelas vagas fazem a sua inscrição e são avaliados por um comitê de especialistas, presidido pelo especialista em gestão de recursos humanos da província, além de outros quatro profissionais, entre eles um representante do sindicato e três profissionais de atuação reconhecida pelos pares.

\subsection{As modalidades de projeto}

São quatro as modalidades de serviços prestados:

- Projeto: dentro dessa modalidade estão os atendimentos voltados para a concepção de novas moradias e para a melhoria de moradias existentes (ampliação, requalificação, divisão e unificação). Esses serviços são demandados tanto pela população quanto pelo Estado. Nessa modalidade também se encontram os desenhos urbanos realizados por demanda do governo.

- Autorização para construção: dentro dessa modalidade estão as autorizações solicitadas para a construção de muros, cisternas, caixas d'água, abrigo para veículo, fossas, melhoria de fachadas e reparação de telhados;

- Parecer técnico: dentro dessa modalidade encontram-se os serviços prestados para auxiliar decisões judiciais e trâmites cartorários, como parecer técnico-construtivos e descrição perimétrica do imóvel, para constar nos registros dos títulos de propriedade;

- Outros serviços técnicos: dentro dessa modalidade estão as visitas técnicas realizadas que não necessitam da elaboração de projetos. 
É no momento da primeira visita técnica à moradia, aquela previamente agendada com 0 arquiteto no encontro acontecido na sede da prefeitura, no qual são levantadas as necessidades dos moradores. Ainda que o acompanhamento de um arquiteto seja condicionante para dar início a qualquer intervenção na moradia, segundo a arquiteta Yaqueline, ocorre em alguns casos, a contratação do mesmo somente após iniciada a obra.

Em uma das visitas que nós acompanhamos com a arquiteta, a construção original se encontrava subdividida em duas unidades: uma no pavimento térreo e outra unidade no pavimento superior. A família era composta pela mãe e dois filhos. A moradia na parte superior tinha apenas um dormitório, a cozinha e um banheiro. $A$ obra já se encontrava em andamento com 0 acréscimo de um cômodo que serviria como sala durante o dia e como dormitório à noite. $A$ área total dos quatro cômodos não ultrapassava $30 \mathrm{~m}^{2}$.

A construção desse novo cômodo implicou na perda de iluminação natural e de ventilação para 0 dormitório e 0 banheiro existentes. A arquiteta, que tinha sido apenas contratada para atestar a construção do novo cômodo, fez também uma avaliação dos outros ambientes para apontar em projeto as medidas a serem adotadas e assim garantir condições

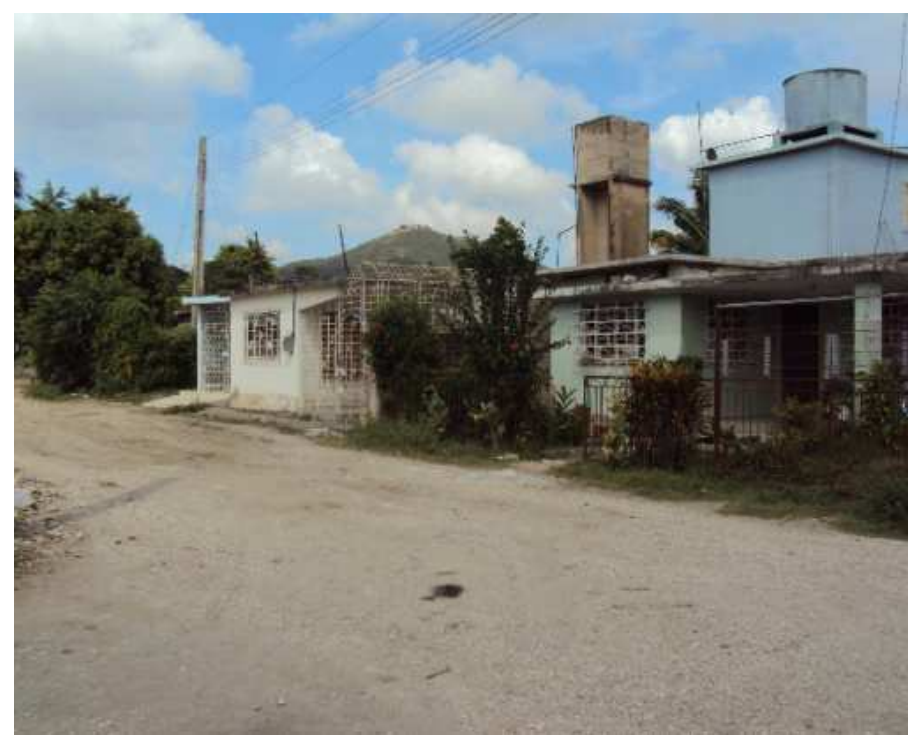

Figura 10. Imagem de uma das casas visitadas localizada ao norte da cidade de Holguín. Fonte: GOMES, 2012.

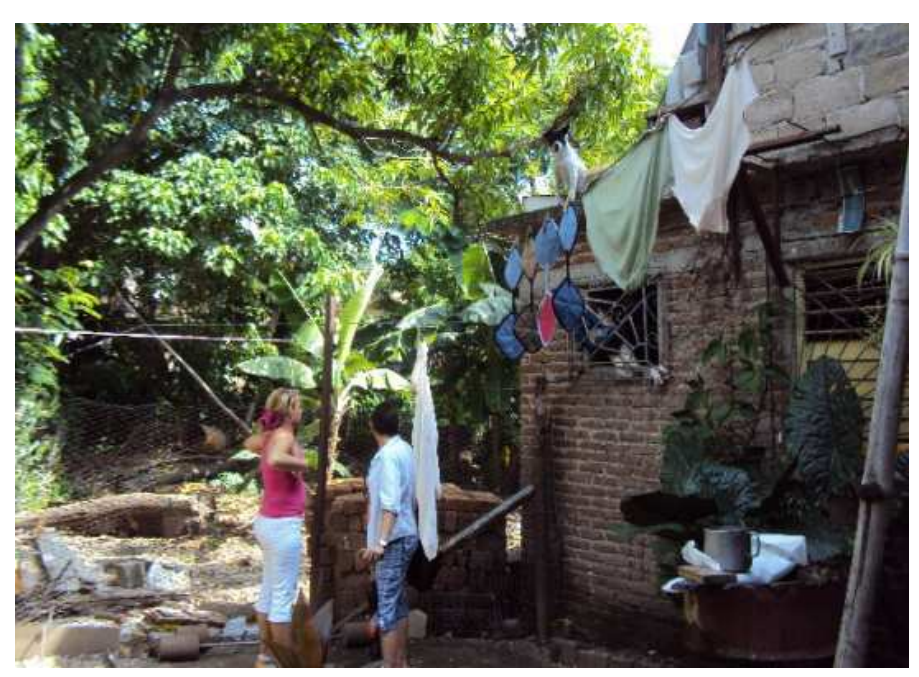

Figura 11. Necessidade de construção do muro de divisa motivou a visita do especialista. Fonte: GOMES, 2012.

mínimas de salubridade, pois é de praxe, independentemente da necessidade levantada pelos moradores, pensar na melhoria da unidade habitacional como um todo. De acordo com Yaqueline, sendo a ampliação realizada apenas com os recursos limitados da família, o projeto apontaria soluções 
bastante simples, como a substituição da porta do banheiro por outra com veneziana para permitir a circulação de ar.

Os arquitetos também são chamados para solucionar conflitos entre vizinhos causados pelas divergências entre divisas dos lotes. Em outra moradia visitada, localizada em um bairro ao norte da cidade de Holguín, a moradora solicitou a visita de um especialista para fazer o projeto do muro de divisa do seu lote (Figuras 10 e 11). A casa originalmente possuía dois pavimentos e foi dividida em duas unidades para abrigar de forma independente a filha que casou. O conflito gerado com o vizinho era ocasionado pelo uso das áreas ao fundo dos lotes que serviam à moradora como área de serviço e ao vizinho como área de lazer. Durante a visita, Yaqueline constatou que existia um vazamento de água na entrada do lote e orientou a moradora a fazer o reparo.

\subsection{0 projeto participativo}

A metodologia de projeto utilizada pelo Programa Arquitetos da Comunidade está baseada em uma concepção de projeto participativo nas intervenções de construções existentes idealizada pelo arquiteto argentino Rodolfo Livingston (1998). Para o arquiteto, apesar das situações que geram a necessidade de ampliação ou de reabilitação das moradias serem as mesmas (geralmente agrega-se novos moradores com o casamento de um filho ou o nascimento de uma criança) as respostas a essas necessidades não são padronizadas e se diferenciam de caso para caso, como explica Laritza Miguel: "[...] cada cliente, familia, vivienda para mí es un caso siempre distinto y único porque las familias son distintas, heterogéneas y su composición, con necesidades diferentes, todas nos aportan algo".

A premissa da metodologia50 se norteia na ideia de que a intervenção em construções existentes requer maior cuidado com as propostas a serem formuladas, uma vez que a família já tem estabelecido uma história com o lugar. Segundo as arquitetas entrevistadas, a metodologia adotada para a elaboração dos projetos de melhorias envolvem as soluções que interferem minimamente na construção. Reconhece-se que grandes intervenções podem causar a rejeição e o sofrimento por parte dos moradores.

A partir da visita técnica realizada junto com os moradores é reconstruído o histórico da moradia, dos moradores e o contexto que se inserem. Nesse momento o profissional, ao observar a interação dos moradores com a casa e diante das possibilidades e das necessidades que a família

\footnotetext{
${ }^{50}$ A metodologia de projeto é intitulada pelos profissionais do programa de "Método".
} 
manifesta, aponta as qualidades da construção e a partir disso apresenta as possibilidades de intervenção, como discute Rabinovich ao explicar a metodologia de trabalho do Programa Arquitetos da Comunidade:

[...] concibe en efecto el "proyecto" como un proceso interactivo entre profesionales y
habitantes que, en sus fases iniciales, esta destinado a definir el problema a resolver y no
solamente a encontrar una solución a un problema dado. Sobre esta base, y gracias al
aporte de disciplinas como la psicología, la sociología y el derecho, y a técnicas de trabajo
simples, es posible tener en cuenta el carácter evolutivo de la demanda de los habitantes y
trabajar con ellos para decodificar sus aspiraciones latentes (Rabinovich, 2002), lo que se
traduce en una mayor adecuación del hábitat y engendra mayor satisfacción.
(RABINOVICH, 2010, s/papud RABINOVICH, 2002)

Portanto, nesta perspectiva, a moradia não é apenas um lugar, mas faz parte da história de vida do morador e não está estagnada, pois os significados e as atribuições que são dados aos espaços se modificam com 0 tempo e 0 arquiteto precisa estar aberto para reconhecer e identificar essas transformações de uso.

A metodologia de projeto utilizada pelos Arquitetos da Comunidade leva em consideração a condição econômica da família. Atualmente, os materiais básicos de construção podem ser acessados de duas maneiras: por meio dos postos de venda do governo e por meio de pequenos empreendedores que recebem autorização do Estado para a produção e a venda dos materiais de construção.

Nos postos do governo é possível comprar os materiais de construção a preços acessíveis. Por exemplo, o metro da barra de aço nestes postos custa nove pesos cubanos enquanto o adquirido de fabricantes independentes chega a custar quinze pesos cubanos. Contudo, a produção estatal dos materiais fica aquém da demanda e, dessa maneira, as pessoas constroem aos poucos. Segundo Laritza Miguel, existem casos em que os moradores receberam licença para a construção desde 1985 e até os dias atuas não finalizaram as obras.

A arquiteta ainda aponta que aqueles que conseguem construir no prazo máximo de um ou dois anos são pessoas que trabalham no setor hoteleiro de Cuba ou que possuem familiares que vivem em outros países e lhes enviam recursos financeiros.

Para exemplificarmos os trabalhos elaborados a partir da metodologia do projeto participativo, apresentaremos três propostas de intervenção realizadas em moradias localizadas no centro histórico 
da cidade de Holguín, sob a responsabilidade da arquiteta Laritza Miguel, uma das fundadoras do Programa Arquitetos da Comunidade ${ }^{51}$, como mencionado anteriormente.

No primeiro caso, a moradia situada a Rua Arias foi atendida no ano de 2000. A casa, construção original dos anos de 1940, encontrava-se em mau estado de conservação. O banheiro que tinha acesso apenas pelo pátio externo da casa foi agregado à parte interna da construção, próximo aos dormitórios, como proposto no projeto. Nesse momento substituiu-se a cobertura de telha cerâmica por laje de concreto armado, como ilustrado nas imagens da Figura 12, gentilmente cedidas por Miguel:
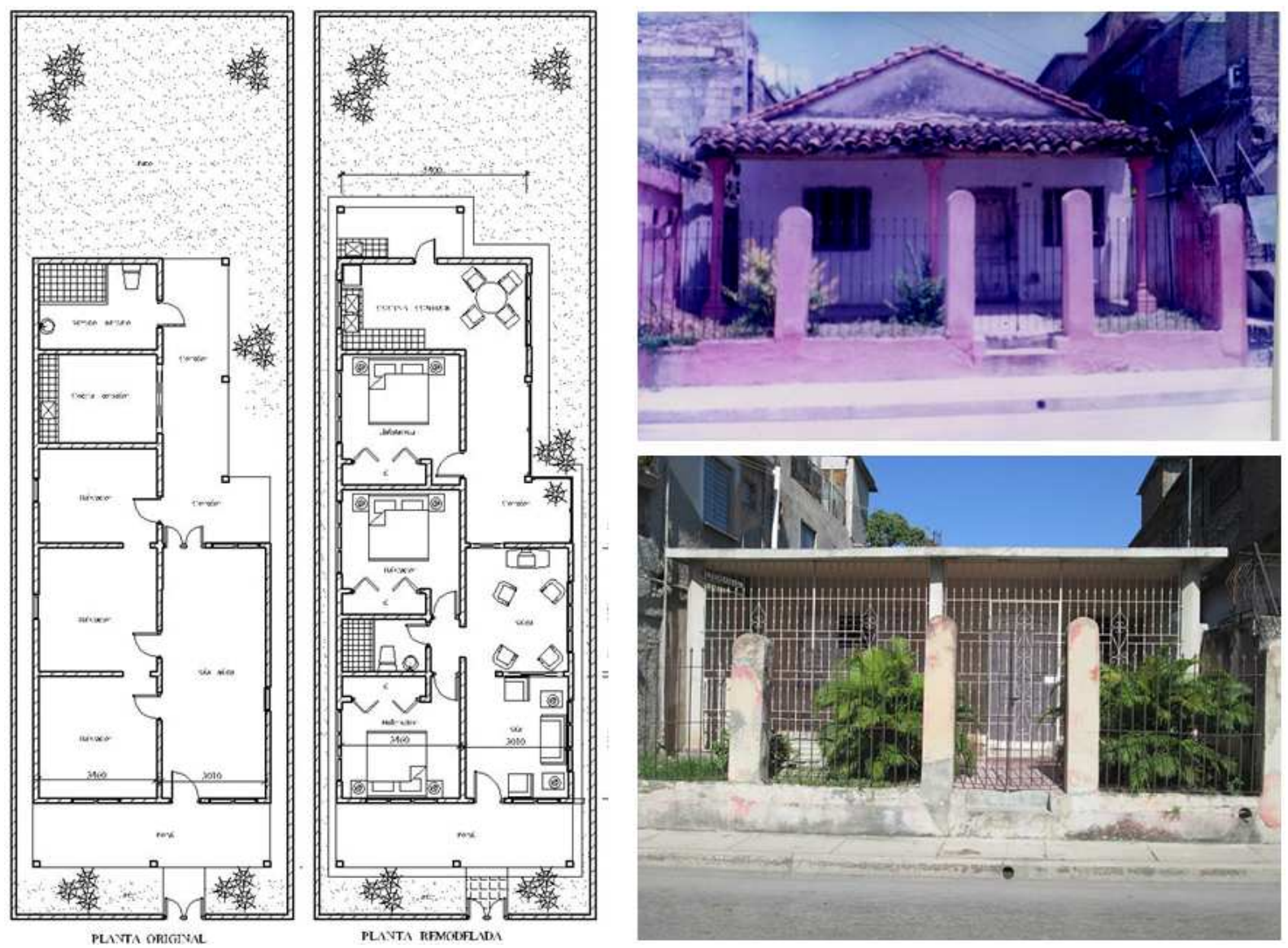

Figura 12. Moradia localizada na Rua Arias: plantas da situação existente durante o levantamento e projeto de melhoria proposto. Fotos da fachada antes e depois das intervenções. Fonte: Laritza García, gentilmente cedidas pela autora

No segundo caso atendido no ano de 2011 e cujas obras atualmente não se encontram concluídas, quando os moradores solicitaram a visita da arquiteta à moradia localizada na Rua Agramonte, parte da edificação sobre a laje de cobertura da casa térrea já estava construída. A construção de uma nova unidade residencial sobre a laje de uma moradia existente é bastante comum e a Lei de Habitação de 1988 regula esse tipo de modalidade. Os moradores haviam construído dois

\footnotetext{
${ }^{51}$ Os três projetos de intervenção foram gentilmente cedidos pela autora.
} 
dormitórios, uma cozinha e um banheiro e seriam construídos mais um dormitório e uma sala que acompanhariam a distribuição dos cômodos da unidade edificada no pavimento térreo. Com a visita da arquiteta foram identificadas as reais necessidades da família e alteradas as funções dos cômodos. A cozinha, anteriormente localizada aos fundos da edificação, passou para a parte da frente da construção, ao lado da sala e próxima da entrada principal da casa (Figura 13), como explica Laritza Miguel:

[...] tenía construido baño, cocina - comedor, dos dormitorios y pasillo y faltaba el frente según su idea inicial y porque la casa de abajo tiene esa distribución otro dormitorio, sala y un balcón y hacer la escalera nueva porque era de tola o metal. Al llegar al arquitecto explicar en qué consiste el método (pacto), luego el sitio o visita con la entrevista ahí conocemos las interioridades de la familia, de la construcción y hasta de los vecinos, sus gustos y necesidades [...] En esta caso el cliente aportó muchas ideas se compenetró con el proyecto y todo fluyo hasta el punto que estuve a pie de obra todo el tiempo un gustazo para mí. Ya cuando presente el estudio de factibilidad o las variantes también con estudio de fachada en el programa Destok [AutoCad] le presente 5 variantes en plantas incluyendo lo que tenían construido. Es decir la vivienda en su totalidad y 4 en fachada tampoco es prudente presentar más yo lo hago solo cuando el cliente pienso es capaz de asimilar todo para no confundirlo, y a los pocos días ya habían decidido cual hacer.

$\mathrm{Na}$ fala da arquiteta podemos destacar dois pontos, o primeiro se refere ao "pacto" que faz parte da metodologia proposta por Livingston, na qual o arquiteto, antes de iniciar o trabalho em conjunto, explica detalhadamente aos moradores todas as etapas que englobam a assistência técnica. O segundo ponto faz referência à sensibilidade da arquiteta em perceber se os moradores estão aptos a compreender uma variedade de propostas, pois nem sempre apresentar várias possibilidades auxilia na tomada de decisão da família. Em alguns casos há de se reconhecer essa limitação para que 0 processo de trabalho não seja prejudicado. 

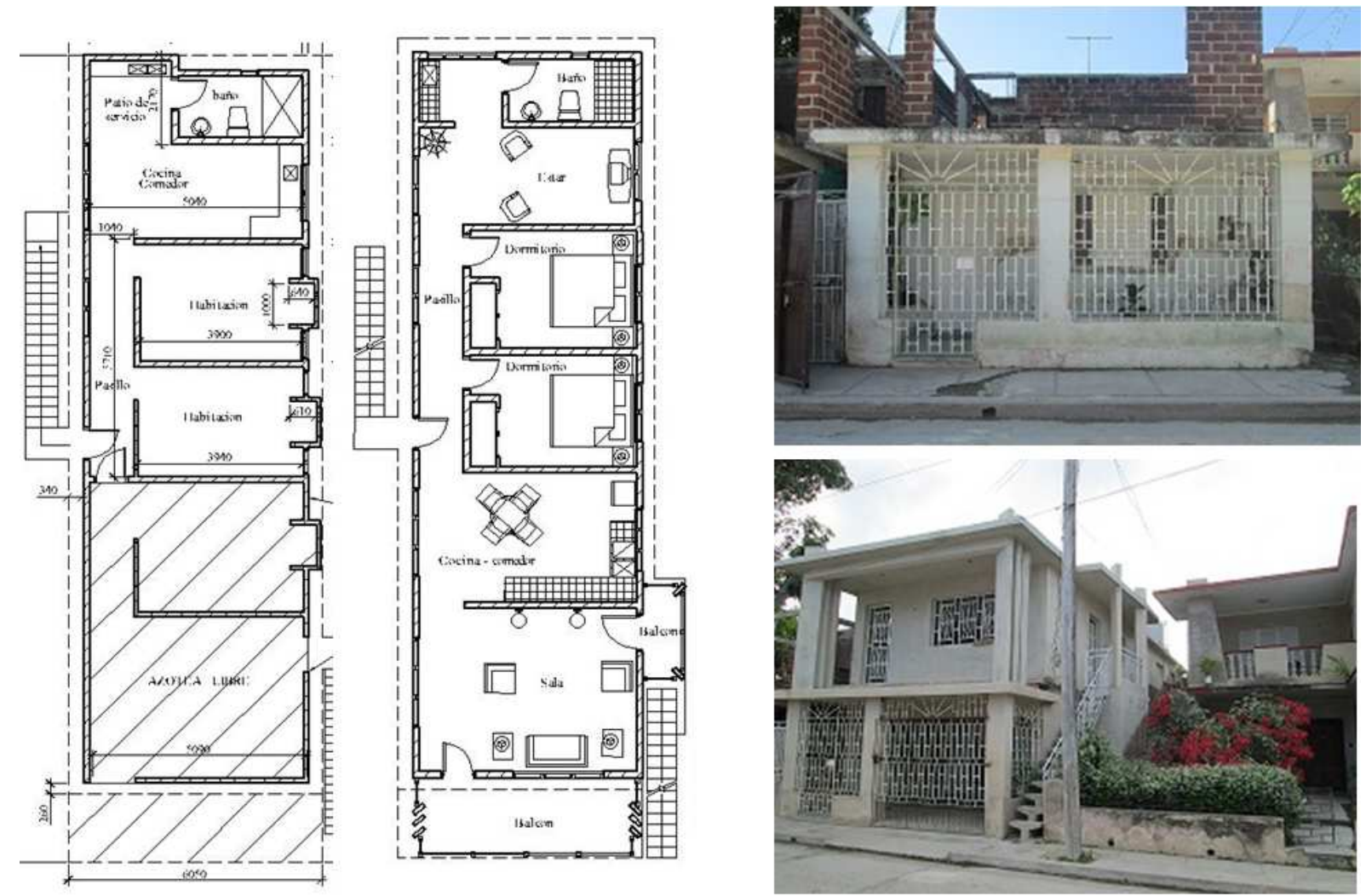

Figura 13. Plantas baixas da casa da Rua Agramonte da situação existente antes da intervenção e da proposta escolhida pelos moradores. Fotos da fachada de antes da intervenção e depois Fonte: Laritza Garcia, gentilmente cedidas pela autora.

O atendimento do terceiro caso foi realizado no ano de 2009. A moradia, localizada na Rua Prado, encontrava-se em mau estado de conservação, sobretudo em relação ao telhado que estava danificado. Além disso, o acesso ao banheiro e a um dos dormitórios era realizado pelo pátio externo. A intervenção proposta integrou todos os ambientes e alterou a função dos cômodos. A função de sala e de dormitório localizados na frente da casa foi mantida, contudo, a cozinha foi transformada em um pátio interno de ventilação, o dormitório interno da casa foi transformado em sala e o banheiro em cozinha. $\mathrm{O}$ dormitório externo foi mantido e foram construídos um banheiro e outro dormitório ao fundo do lote. Também foi substituída a cobertura de telhas por uma laje de concreto armado, conforme Figura 14. 

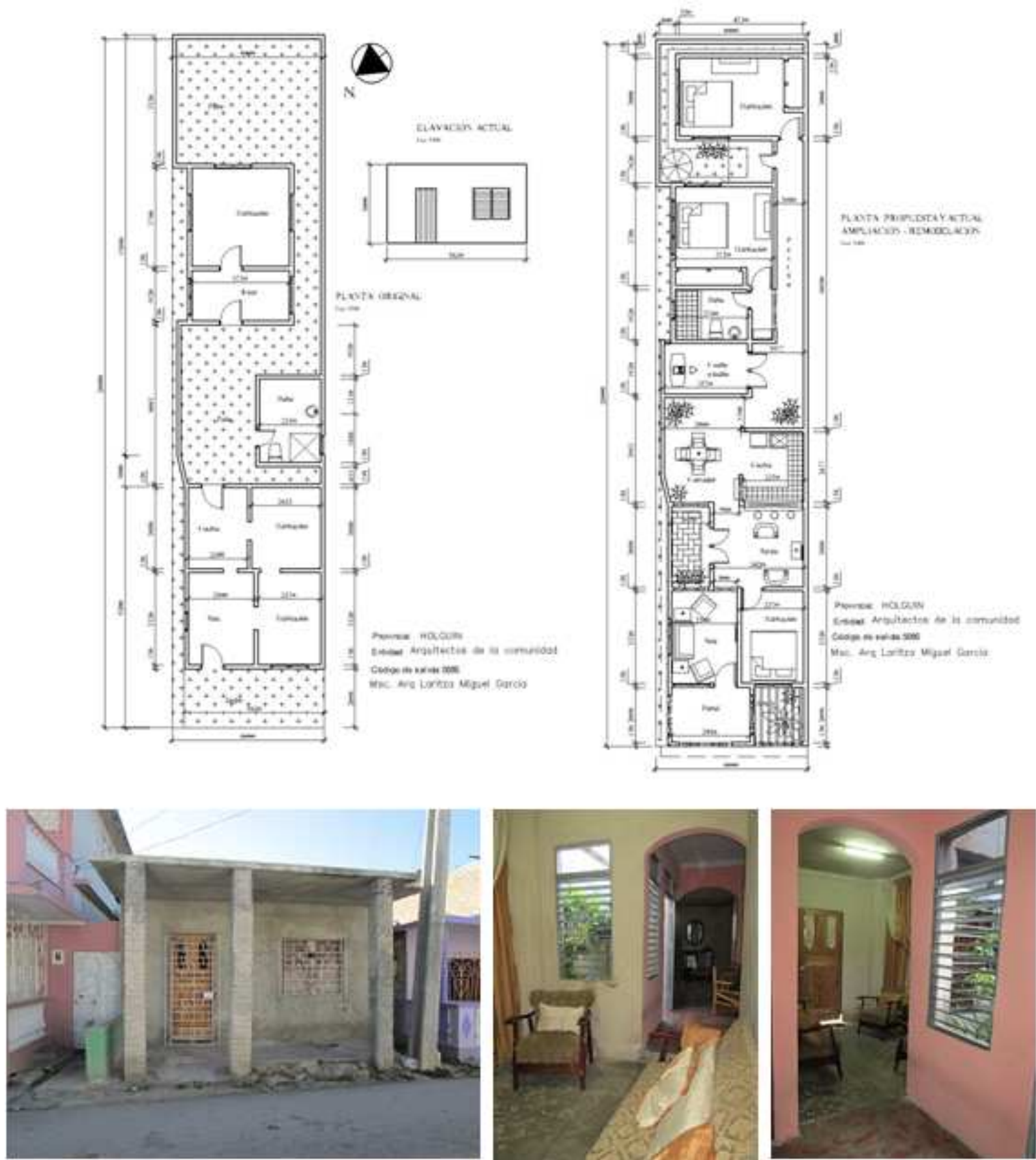

Figura 14. Moradia localizada na Rua Prado: plantas da situação existente durante o levantamento e projeto de melhoria proposto. Fotos da fachada de antes e depois das intervenções. Fonte: Laritza Garcia, gentilmente cedidas pela autora.

Nas três intervenções, após ser realizado um levantamento por parte da arquiteta das novas necessidades das famílias, foram recorrentes as propostas de alterações de funções dos cômodos existentes. Podemos notar também que são habituais as substituições das coberturas de telhas por lajes de concreto. Isso ocorre pela carência de reposição das telhas cerâmicas, pois estas são usualmente danificadas pelas tempestades e pelos furacões que atingem o país. Pela dificuldade de 
acesso aos materiais de construção, é de praxe o reaproveitamento dos materiais em bom estado, como as esquadrias, as louças sanitárias dos banheiros e as tubulações de água e de esgoto.

Em relação à apresentação dos projetos, os arquitetos fazem uso habitualmente de plantas baixa desenhadas em AutoCad, no entanto, quando julgam necessário, também utilizam o desenho à mão, o que thes possibilita uma maior liberdade de criação e torna mais didática a leitura da planta. Para Laritza Miguel, a utilização de cores para distinguir as propostas de intervenções da situação existente é uma maneira encontrada por ela para superar a dificuldade que muitos moradores apresentam em compreender as plantas:

\begin{abstract}
Cuando los cito para la oficina para explicar las variantes [são apresentadas três propostas de intervenção] muchos no entienden, al principio. $Y$ hasta hace casi 3 años aproximadamente me gustaba y todavía me gusta hacer las variantes a mano alzada porque me da libertad de creación. Les explico casi todo "estos son los muros, ventanas, puertas" y lo trabajo con colores para diferenciar muros nuevos, los que se eliminan, le adiciono en cada variante los $\mathrm{m}^{2}$ que se amplían en dependencia del caso, para hacer análisis de la economía familiar y luego se las llevan para su casa para analizarlas en familia. Me ha sucedido que en el mismo momento me dicen "esta es la que queremos" y yo les digo "pero no hay apuro analicen con calma". Otros se las llevan pero a los dos días se aparecen ya con la solución escogida. Y también está el que se aparece con una fusión de dos variantes o la minoría que se quedan con su idea inicial, (hay de todo). Aceptan las variantes en su mayoría las entienden y sino uno de la familia la entiende y le ayuda al otro.
\end{abstract}

Como ainda explicou a arquiteta, comumente são apresentadas três possibilidades de intervenção para cada projeto. Laritza Miguel entrega os projetos aos moradores sem pressioná-los a tomarem uma posição; pelo contrário, compreende que a família precisa de tempo para assimilar o que foi proposto e, assim, discutir e decidir a intervenção que melhor se aproxima dos anseios de todos. Nesse sentido, a arquiteta divide com os moradores a responsabilidade do projeto e dá peso à decisão da família.

\title{
3.7 O papel do arquiteto dentro do programa
}

Ao longo dos 20 anos de atuação do Programa, o trabalho dos arquitetos passou a ser reconhecido à medida que a população fazia uso dos serviços e se sentia contemplada e satisfeita com os resultados. Esta credibilidade consolidada no Programa é também creditada aos profissionais e, portanto, não há necessidade de realizar com cada morador um trabalho de reconhecimento sobre 0 papel desempenhado pelos arquitetos e pelos engenheiros. De acordo com Laritza Miguel, para que a população atribua nos dias de hoje o respeito por estes profissionais, foi necessário um trabalho de aproximação que se iniciou com a fundação do programa e se estendeu ao longo dos anos de atuação: 


\begin{abstract}
Al iniciarse este programa los arquitectos no éramos muy solicitados, pues los proyectos de la población eran hechos por otras entidades y la población piensa que ellos saben construir y de hecho construyen, quitan, ponen a su manera sin respetar el proyecto [...] Con los años se fue divulgando esta forma de hacer arquitectura, se convencieron que si funciona porque así lo demostramos con el trabajo y entre los mismos clientes que le aconsejaban a otros "ve al arquitecto de la comunidad que te dan ideas", generalmente se acercaban a nosotros profesionales interesados en que sus casas no tuvieran el mismo modelo de las que están construidas, y así fue teniendo auge entre la población [...] En entrevistas y encuestas realizadas, más del $90 \%$ de la población, ve al programa del Arquitecto de la Comunidad como una solución satisfactoria a sus problemas [...].
\end{abstract}

O respeito e o reconhecimento citados por Laritza Miguel se deve em parte pela formação do profissional, que deve ter uma experiência prática de dois anos antes de assumir o cargo de Especialista em Conservação e Reabilitação, como mencionado, e pelo seu perfil que deve ter como característica a empatia para se trabalhar diretamente com a população.

A remuneração dos profissionais, a conduta tanto no atendimento à população quanto no local de trabalho, os prazos de elaboração dos serviços constam no regulamento interno do funcionamento do programa. Cada província estabelece o seu próprio regulamento como os prazos fixados para a entrega dos projetos, as penalidades aplicadas pelo descumprimento dos prazos ou o mau atendimento a população, as ausências ou os atrasos injustificados, conforme expresso no Art. 29 do Cap. IV do Regulamento Interno da província de Holguín estabelecido para o pagamento dos profissionais:

Penalizaciones para los trabajadores directos expresadas en porciento.

- Tener algún servicio o trámites fuera de los términos establecidos. Teniendo en cuenta la fecha de entrada de los mismos a la Unidad Presupuestada y atendiendo a que los proyectos tienen como máximo 60 días y los trámites 30 , se penaliza con hasta el $5 \%$ del total de sobrecumplimiento por cada trámite fuera de fecha.

- Calidad en la elaboración de los Proyectos y trámites con los clientes, se penalizará con el $5 \%$ por cada error u omisión que cometa.

- $\quad$ Tener ausencias o llegadas tardes al Servicio de guardia se penaliza hasta el $50 \%$ del total del sobrecumplimiento.

- Que existan quejas verificadas de los clientes con respecto al trato o la atención recibida. La penalización será del $100 \%$ del monto total del sobrecumplimiento.

- $\quad$ Tener ausencias injustificadas a reuniones o despachos programados. ( por primera vez, se penaliza con el $10 \%$, si reincide dentro del mes se penaliza con el $100 \%$ )

- $\quad$ Ser sancionado administrativamente dentro del período por algunos de los hechos 0 conductas previstos en el Reglamento Disciplinario Interno, perderá el derecho al cobro del sobrecumplimiento obtenido. (ARQUITECTOS DE LA COMUNIDAD - PROVINCIA HOLGUíN, 2012, s/p)

Os arquitetos também podem ser processados pela população por erros ou por faltas cometidas. Na província de Holguín, desde a fundação do programa até o ano de 2012, houve nove processos abertos contra os profissionais e apenas uma condenação dentro do universo dos 185 mil atendimentos. 
Durante a execução das obras, o especialista se torna responsável pela fiscalização do cumprimento correto dos parâmetros estabelecidos em projeto. Caso haja descumprimento daquilo que está determinado em projeto, o profissional pode solicitar a paralisação da obra. Se o morador insistir em executar a obra em desacordo com o projeto, ele recebe uma multa, como nos explicou Ricardo Martinez:

De violarse lo proyectado el Especialista puede proponer la paralización de la obra. Legalmente el arquitecto debe velar por que se cumpla lo establecido por proyecto pero la medida correctiva se aplica al ejecutor de la obra en los casos que éstas sean estatales. En los casos que sean particulares la decisión es del cliente. En este caso si el ejecutor viola lo establecido por proyecto y el cliente está de acuerdo en continuar la obra y no escucha las recomendaciones del Arquitecto, estatalmente se le impone una multa al infractor, en este caso el cliente.

O papel que os Arquitetos da Comunidade assumiram diante da população é aquele que será responsável pelo apontamento das questões legais que envolvem a moradia, tanto do ponto de vista arquitetônico, em relação às normas edilícias, quanto do ponto de vista urbanístico, em relação às regras de ocupação do solo.

O programa ao ser incorporado à política pública de Cuba, em 1998, condicionou a população a associar também o arquiteto a um agente do $\operatorname{Estado}^{52} \mathrm{e}$, portanto, um fiscalizador do governo, que é usado para apontar as irregularidades cometidas pelos moradores em relação à moradia e à aquisição de materiais de construção, conforme discute Coyula $(2006)^{53:}$

[...] el celo que se aplica en perseguir ilegalidades en la vivienda o el la adquisición de materiales no alcanza a las obras improcedentes, que también son ilegales [...] Irónicamente, la línea actual parece ser convalidarlas; y para ello se usa los Arquitectos de la Comunidad, que habían sido concebidos para asesorar a la población en las intervenciones dentro de sus viviendas, y ahora se han transformado en inspectores-funcionarios.

Livingston (2009) ponderou que a função de fiscalização das normas municipais estabelecidas, ao regular a distribuição do material de construção entre a comunidade, foi transmitida aos Arquitetos da Comunidade justamente pela relação de confiança que os profissionais estabeleceram com a população. De acordo com o autor, em Cuba, pela limitação no acesso ao material de construção, não se admitia que as pessoas com mais recursos tivessem acesso aos materiais de construção enquanto que outras com menos recursos, não conseguissem obtê-los; por isso a necessidade da fiscalização.

\footnotetext{
${ }^{52}$ Em minha estadia na cidade de Holguín, durante o acompanhamento das visitas às casas atendidas, assim que eu entrava na moradia era apresentada pelas arquitetas como uma estudante do Brasil e era necessário deixar evidente que eu não era funcionária do governo cubano.

${ }^{53}$ Arquiteto e Professor Emérito do curso de Arquitetura da Faculdade de Arquitetura da Universidade de Cuba - CUJAE.
} 
Rabinovich (2010) apontou que essas funções que os Arquitetos da Comunidade assumiram comprometeram o desenvolvimento do programa e o seu caráter inovador. Segundo a autora:

Fue en 1998, cuando los AC [Arquitetos da Comunidade] gozaban de un amplio reconocimiento nacional e internacional, que el programa fue integrado en el jirón del estado cubano. Su incorporación en el marco de las políticas públicas se consideró un éxito que permitiría ampliar y replicar los resultados del AC enriqueciendo a su vez los planes y programas sectoriales existentes. Sin embargo, el pasaje bajo la tutela del Instituto de la Vivienda no permitió garantizar las condiciones institucionales necesarias a la innovación, lo que ha tendido a desnaturalizar el programa y frenar su crecimiento (s/p).

Livingston (2009) apontou ainda que em alguns grupos dos Arquitetos da Comunidade optouse pela contratação de técnicos de nível médio para se encarregar das fiscalizações, permitindo com que os arquitetos e engenheiros dedicassem maior tempo à elaboração dos projetos e, dessa forma, não se distanciassem da proposta que originou o programa.

Anualmente, os profissionais realizam avaliações sobre o programa desenvolvido em cada província. Em relação à província de Holguín, os desafios apontados nos relatórios de avaliação se restringem basicamente à manutenção e ao funcionamento da estrutura dos escritórios e a falta de materiais básicos de papelaria, como papel para impressão. Dez dos 14 municípios que compõem a província de Holguín não possuem escritórios independentes.

Os profissionais recebem formação continuada dentro do Programa. São fornecidos cursos de computação, técnicas construtivas compatíveis com os problemas enfrentados pelo país, métodos de diagnóstico da construção e de suas patologias, instalações elétricas, hidráulico-sanitárias, estruturais e cursos que abordam os aspectos legais que envolvem a habitação. São também realizados treinamentos com os profissionais ingressantes para que eles se tornem aptos a utilizarem a metodologia de projeto do programa.

\subsection{Resultados alcançados}

De acordo com dados fornecidos pelo escritório de Holguín, a província contabilizou no ano de 1994, 618 atendimentos, e em 2012, registrou mais de 35 mil atendimentos, totalizando, desde a sua criação, 185 mil atendimentos. A Figura 15 ilustra a distribuição dos atendimentos durante os 19 anos de existência do programa. É perceptível a importância que os Arquitetos da Comunidade assumem ao longo dos anos, culminando no ano de 2012 com mais de 35 mil atendimentos. 


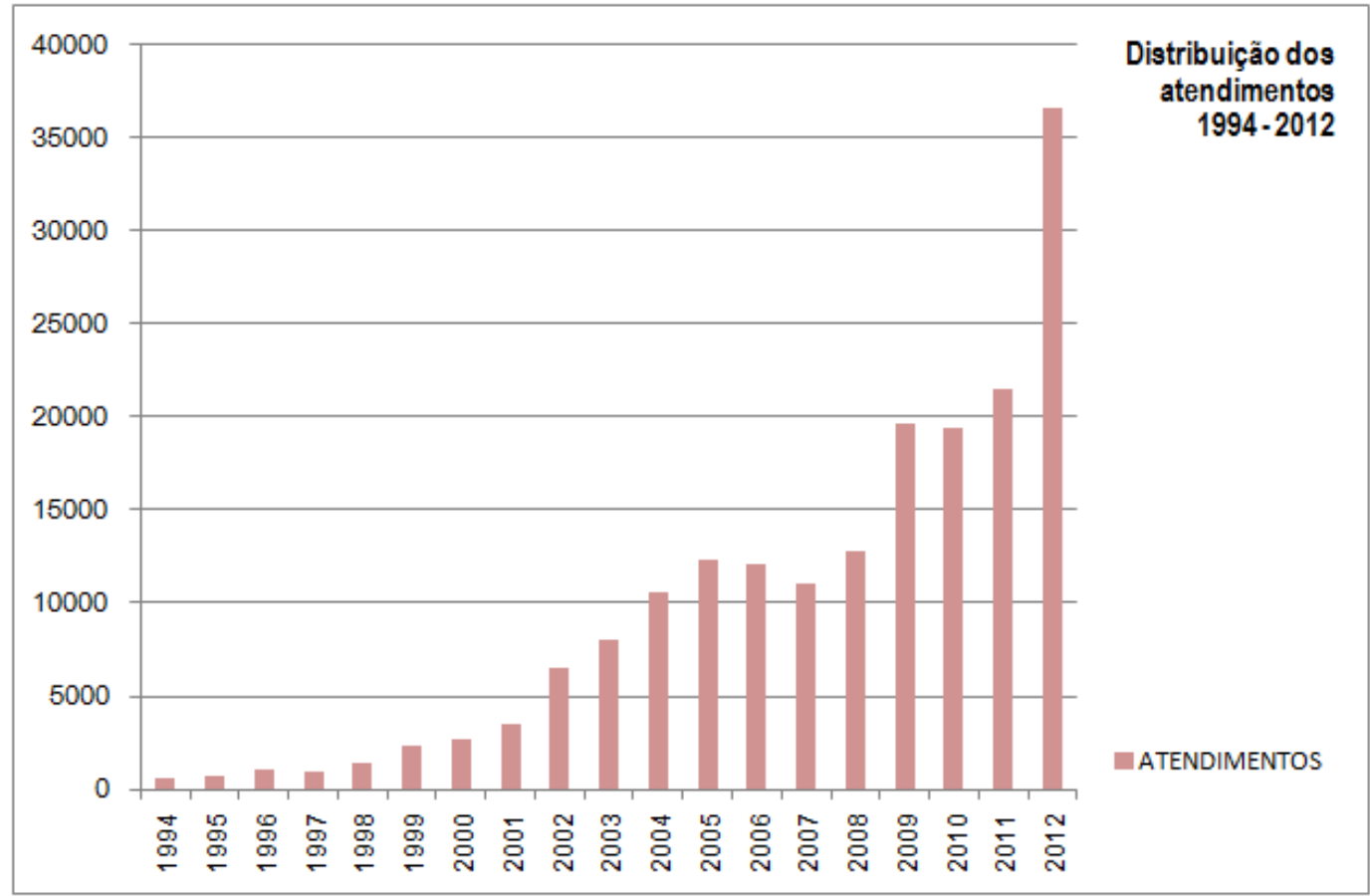

Figura 15. Número de atendimentos realizados por ano entre 1994 e 2012. Fonte: AC, 2013

$\mathrm{Na}$ Figura 16, apresentamos a distribuição dos atendimentos por modalidade de serviço contratado entre os anos de 2008 a 2012. Podemos notar nos cinco anos analisados que a maior demanda pelos serviços dos Arquitetos da Comunidade é para a realização dos pareceres técnicos que subsidiam a elaboração dos títulos de propriedade da moradia. Qualquer alteração construtiva realizada na moradia também deve ser sucedida pela correção dos títulos de propriedade. Por exemplo, se for realizada uma melhoria em uma moradia que envolve a colocação de revestimento, redistribuição espacial dos cômodos, alteração de área construída, mudança de tipo de cobertura etc., além da elaboração do projeto, se faz necessária à correção das descrições do título de propriedade. A mesma unidade residencial contratará dois serviços distintos e, desse modo, será contabilizada tanto dentro da modalidade "Projeto" quanto dentro da modalidade "Parecer Técnico".

Como já mencionado, existiam na província de Holguín, em 1994, 14 profissionais e nesse ano foram realizados 618 atendimentos, uma proporção de 44 atendimentos por profissional, resultando em uma média mensal de 3,6 atendimentos.

Em 2009, foi publicada pelo Instituto Nacional de Habitação uma resolução ${ }^{54}$ que tinha como proposta flexibilizar os procedimentos para o registro de propriedade das moradias. Para tanto, os

\footnotetext{
${ }^{54}$ Resolução n ${ }^{0} 50$ de 23 de fevereiro de 2009
} 
Arquitetos da Comunidade foram apontados no documento como os profissionais que deveriam realizar os pareceres técnicos que embasariam os registros.

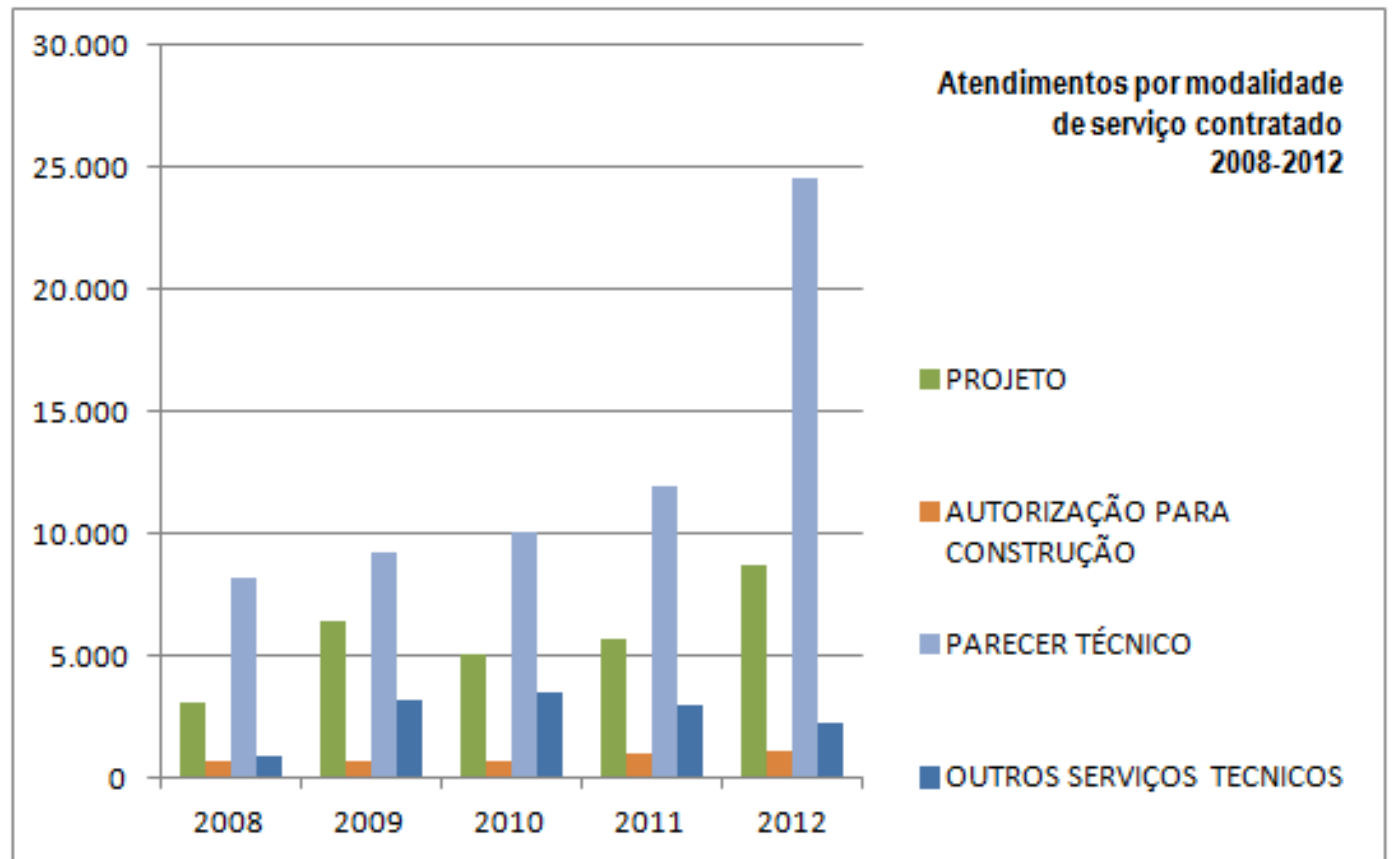

Figura 16. Número de atendimentos por modalidade de serviço contratado entre os anos de 2008 e 2012. Fonte: AC, 2013

Em 2010, quando existiam 61 profissionais entre arquitetos e engenheiros, foram realizados, aproximadamente, 20 mil atendimentos, sendo cinco mil atendimentos demandados para elaboração de projeto e dez mil atendimentos demandados para elaboração de parecer técnico. Dessa forma, nesse ano, cada profissional foi responsável pelo atendimento de 328 solicitações, uma média mensal de 27 atendimentos, sendo que 50\% corresponderam à emissão de parecer técnico e $25 \%$ ao atendimento de demandas para elaboração de projetos.

Em 2011, a Lei de Habitação de 1988 foi alterada por um decreto-lei e nela suprimida a proibição da compra e da venda de moradias. Para a efetivação dos direitos de propriedade do imóvel o decreto apontou como obrigatório o registro dos títulos de propriedade no cartório de imóveis.

No ano seguinte à publicação do decreto-lei, o número de atendimentos foi superior a 35 mil, sendo que desse total, aproximadamente, 25 mil corresponderam à emissão de parecer técnico e por volta de nove mil atendimentos relacionados à elaboração de projeto. Sem o incremento no número de profissionais, nesse ano, cada arquiteto e engenheiro respondeu, em média, por 573 atendimentos, 48 atendimentos por mês, sendo que 70\% corresponderam a solicitação para emissão de parecer técnico e $25 \%$ dos atendimentos para a elaboração de projeto. 
Aparentemente, o resultado dessa sobrecarga de trabalho para os profissionais pode ter contribuído para que a população se aproximasse mais do programa e conhecesse 0 trabalho dos arquitetos. Contudo, uma das arquitetas entrevistadas 55 em 2012 declarou que realizava satisfatoriamente 12 projetos por mês, mas que a demanda pela emissão do parecer técnico que tinha se tornado mais acentuada naquele ano era um fator que desestimulava a profissional, uma vez que não permitia a dedicação que ela considerava adequada à elaboração dos projetos.

É premissa do programa o atendimento das solicitações no menor espaço de tempo, devendo o profissional respeitar todos os prazos estabelecidos no regulamento interno dos Arquitetos da Comunidade com o risco de serem punidos, caso descumpram qualquer regra. Portanto, os profissionais se sentem, por um lado, pressionados a responderem as solicitações de atendimento que, entre 2011 e 2012, aumentou em mais de 70\% e, por outro lado, comprometidos com a elaboração dos projetos seguindo a metodologia adotada pelo programa.

De acordo com Livingston (2009) existe o receio de que a metodologia de trabalho realizada pelos Arquitetos da Comunidade se submerja frente à burocracia colocada a esses profissionais, pois nas palavras do arquiteto:

Estamos conscientes del riesgo de que, con el transcurso del tiempo, pueda llegar a perderse la esencia del Método dentro de alguna red burocrática, pero su espiritu humanista ha calado hondo en la mente de los arquitectos y no es fácil desalojarlo de allí. Todos deseamos que ese espiritu se mantenga y tenemos mucha confianza en que será así (LIVINGSTON, 2009, p. 275).

Portanto, dentro deste contexto, cabem aos profissionais que atuam nos grupos dos Arquitetos da Comunidade fazerem com que as motivações que originaram o programa não sejam anuladas frente as novas demandas que o Estado impõe a eles. Mas é importante também que as regras que estabelecem os prazos para cumprimento da elaboração dos serviços possam ser repensadas e assim contribuir para que a qualidade do programa seja mantida.

Cada grupo provincial possui um líder que é, geralmente, o profissional mais experiente do grupo. Segundo Livingston (2009), são realizados seminários periódicos com os grupos provinciais dos Arquitetos da Comunidade em todo o país, nos quais se analisam os projetos que os profissionais desenvolveram ao longo de um determinado período de tempo e se avalia o desempenho da liderança dos grupos.

\footnotetext{
${ }^{55}$ Nesse momento, preferimos não identificar a arquiteta, pois a crítica feita por ela foi a tom de desabafo.
} 
Na Figura 17 apresentamos o número de atendimentos realizados de acordo com o tipo de serviço contratado dentro da modalidade "Projeto". Podemos notar que os projetos de melhorias e de ampliações contratados diretamente pela população respondem pelo maior número de atendimentos prestados. Em consequência da passagem do furacão lke, no final do ano de 2008, o número de projetos de melhoria e de ampliação das unidades existentes contratados pelo Estado aumentou significativamente no ano seguinte, 2009, e se igualou ao número daqueles contratados pela população para a realização do mesmo serviço.

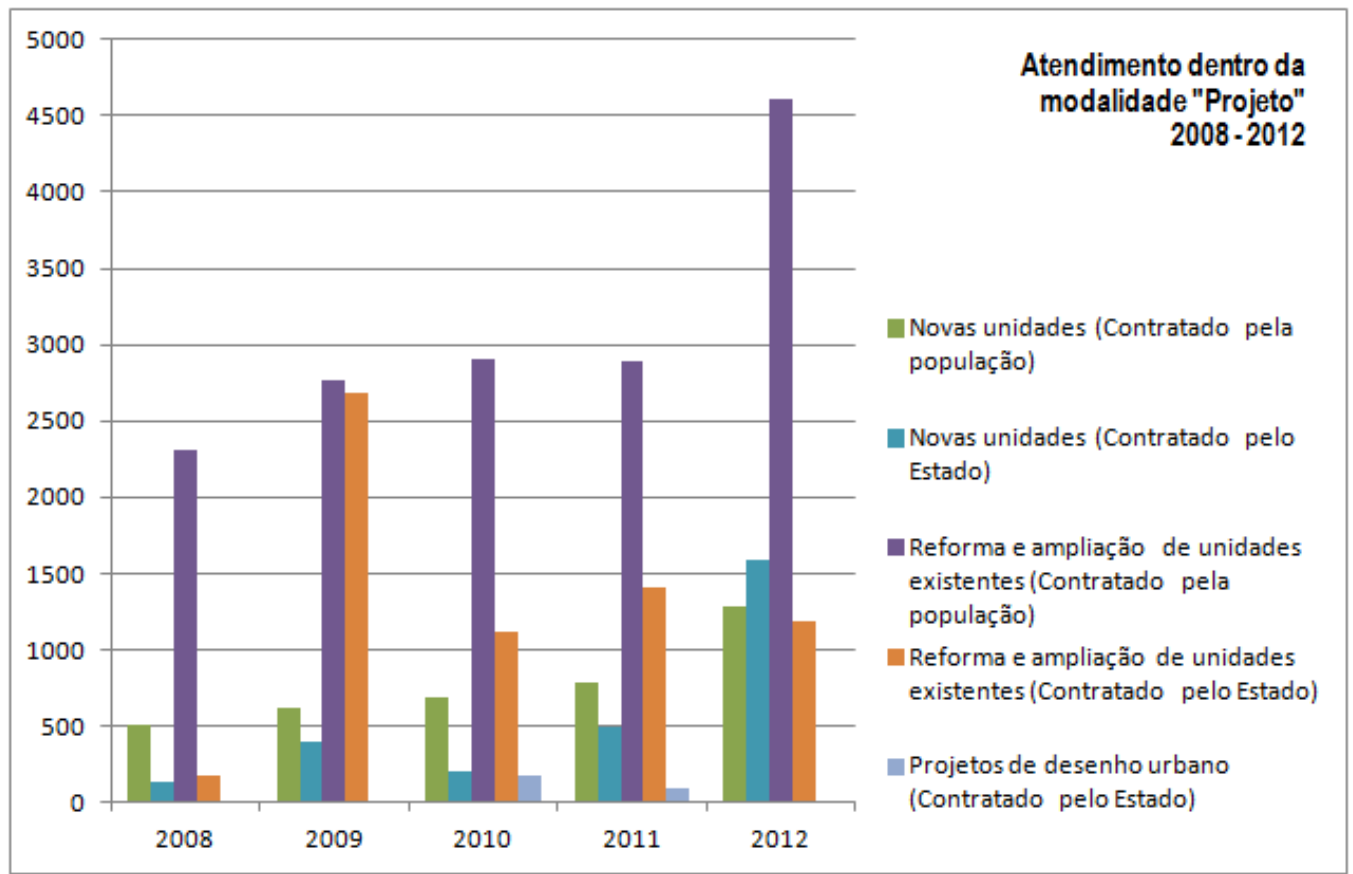

Figura 17. Distribuição dos atendimentos realizados dentro da modalidade "Projeto" entre os anos de 2008 e 2012. Fonte: AC, 2013

Nessa figura também notamos que a contratação de projetos para a construção de novas unidades diretamente pela população demonstra uma tendência de aumento nos cinco anos analisados. Enquanto as demandas por projetos de desenho urbano pelo Estado somente apareceram no ano de 2010, provavelmente motivada pelo direcionamento dos recursos, no ano anterior, para atender a demanda por moradia em decorrência da passagem do furacão.

A Figura 18 apresenta 0 número de atendimentos realizados dentro da modalidade "Autorização para construção" distribuídos por tipo de obra. São solicitações para intervenções simples, nas quais o profissional somente analisa a condição encontrada e libera a construção. Dentro desse universo, percebemos que o muro de divisa dos lotes é o tipo de intervenção com maior número de ocorrências em todos os anos registrados, provavelmente devido aos conflitos entre vizinhos pelo uso dos espaços, seguido da reforma da fachada e da construção de cisternas. Com números menos 
expressivos, encontramos as solicitações para construção de caixas d'água, de fossas e de abrigos para automóveis.

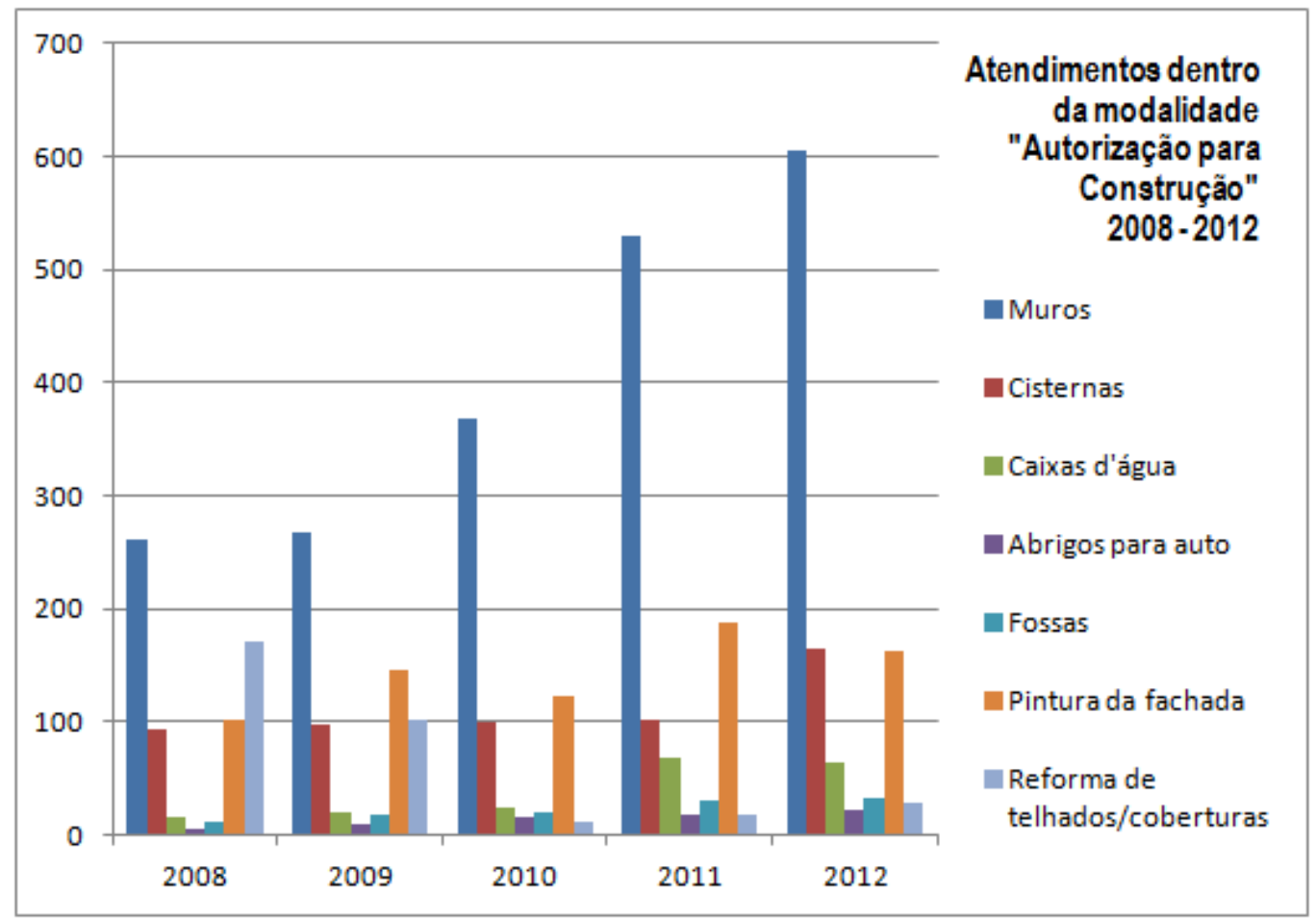

Figura 18. Distribuição dos atendimentos realizados dentro da modalidade 'Autorização para Construção' entre os anos de 2008 e 2012. Fonte: AC, 2013

\subsection{Conclusões}

Após 20 anos de atuação dos Arquitetos da Comunidade, percebemos que apesar dos desafios habitacionais que o país vivencia por conta da crise e do embargo econômico sofrido, 0 programa está bem estruturado e tem cumprido com sucesso o seu objetivo final, dentro das suas limitações.

$\mathrm{Na}$ Tabela 2, sistematizamos os principais apontamentos discutidos neste capítulo ao elencarmos as dificuldades e as conquistas do programa.

Tabela 2. Dificuldades e conquistas do Programa Arquitetos da Comunidade.

\begin{tabular}{|l|l|l|}
\hline $\begin{array}{l}\text { Aspectos } \\
\text { analisados }\end{array}$ & Dificuldades & Conquistas \\
\hline $\begin{array}{l}\text { 1) Estratégias } \\
\text { de divulgação } \\
\text { e acesso ao }\end{array}$ & $\begin{array}{l}\text { - Quantidade de profissionais que pode } \\
\text { se tornar incompativel com a demanda, } \\
\text { uma vez que a demanda pelos } \\
\text { pareceres técnicos, especialmente os }\end{array}$ & $\begin{array}{l}\bullet \text { Divulgação dos serviços nos meios de comunição } \\
\text { de massa (TV); }\end{array}$ \\
\hline
\end{tabular}




\begin{tabular}{|c|c|c|}
\hline serviço & $\begin{array}{l}\text { cartorários, ocupam boa parte do tempo } \\
\text { dos profissionais comprometendo o } \\
\text { desempenho dos mesmos. }\end{array}$ & $\begin{array}{l}\text { de } 10 \text { mil moradores na área urbana; } \\
\text { - Sistematização do atendimento; } \\
\text { - Instalação de escritórios na área central; } \\
\text { - Uniformização dos serviços prestados; } \\
\text { - Custo dos serviços acessíveis à população } \\
\text { (universalização do acesso); } \\
\text { - Instalação de escritórios acessíveis à população; } \\
\text { - } \text { Atendimento em curto espaço de tempo. }\end{array}$ \\
\hline $\begin{array}{l}\text { 2) } \\
\text { Aproximação } \\
\text { dos } \\
\text { profissionais } \\
\text { junto à } \\
\text { população }\end{array}$ & $\begin{array}{l}\text { - Há ainda clientes que iniciam as obras } \\
\text { antes da contratação do profissional }\end{array}$ & $\begin{array}{l}\text { - Visão cultural positiva do profissional construída } \\
\text { historicamente com o Programa; } \\
\text { - A garantia da continuidade da prestação do serviço. } \\
\text { - O conhecimento por parte dos profissionais } \\
\text { (arquitetos e engenheiros) dos aspectos } \\
\text { construtivos e jurídicos que envolvem a moradia. } \\
\text { - Elaboração de projeto participativo onde se avaliam } \\
\text { a história da moradia e a interação dos moradores } \\
\text { com a casa. } \\
\text { - Formas simples e didáticas de apresentação do } \\
\text { projeto. As dificuldades nas leituras das plantas são } \\
\text { ultrapassadas pela disponibilidade dos profissionais } \\
\text { em sanarem as dúvidas junto aos moradores. } \\
\text { - Descrição específica das responsabilidades, } \\
\text { benefícios e penalidades a que os profissionais } \\
\text { estão sujeitos, bem como sua efetiva aplicação. } \\
\text { - Os mesmos profissionais são responsáveis pelo } \\
\text { atendimento de regiões determinadas do município. } \\
\text { - Os vínculos criados com os profissionais chegam ao } \\
\text { ponto dos moradores fidelizarem-se com } \\
\text { determinados profissionais. }\end{array}$ \\
\hline $\begin{array}{l}\text { 3) Elaboração } \\
\text { do projeto } \\
\text { personalizado }\end{array}$ & $\begin{array}{l}\text { - Não ter a certeza do contato com a } \\
\text { mão de obra. }\end{array}$ & $\begin{array}{l}\text { - Após a formaçãa do profissional, é necessário fazer } \\
\text { uma espécie de residência por dois anos para se } \\
\text { especializar nas funções que o cargo de } \\
\text { Especialista em Conservação e Reabilitação exige. } \\
\text { - Cinco profissionais experientes selecionam os } \\
\text { arquitetos e engenheiros que assumirão os cargos } \\
\text { de Especialistas em Conservação e Reabilitação. } \\
\text { - Reuniões semanais entre os profissionais do grupo } \\
\text { para discussão dos trabalhos em desenvolvimento. } \\
\text { - A metodologia Livingston adotada pressupõe uma } \\
\text { formação mais variada e interdisciplinar (psicologia, } \\
\text { sociologia, direito e técnicas de trabalho simples) } \\
\text { com reflexo direto sobre o profissional que atuará no }\end{array}$ \\
\hline
\end{tabular}




\begin{tabular}{|c|c|c|}
\hline & & $\begin{array}{l}\text { Programa. } \\
\text { - Formação continuada dos profissionais; }\end{array}$ \\
\hline $\begin{array}{l}\text { 4) Resultados e } \\
\text { limitações }\end{array}$ & $\begin{array}{l}\text { - Os especialistas assumiram o papel de } \\
\text { agentes fiscalizadores do governo o que } \\
\text { pode limitar os espaços para as } \\
\text { constantes inovações do trabalho; } \\
\text { - Assumiram funções cartorárias ao } \\
\text { serem designados em lei como } \\
\text { responsáveis pelas correções dos } \\
\text { títulos de propriedade dos imóveis; } \\
\text { - Faltam escritórios independentes em } \\
\text { dez dos } 14 \text { municípios que compõem a } \\
\text { província de Holguín; } \\
\text { - } 40 \% \text { dos profissionais (arquitetos e } \\
\text { engenheiros) não utilizam o AutoCad ou } \\
\text { qualquer outro software como } \\
\text { ferramenta de desenho. }\end{array}$ & $\begin{array}{l}\text { - Reconheceu-se a importância dos profissionais } \\
\text { (arquitetos e engenheiros) na contribuição das } \\
\text { soluções dos problemas envolvendo a moradia; } \\
\text { - Até o ano de } 2012 \text { já tinham sido realizados mais de } \\
185 \text { mil atendimentos na província de Holguín; } \\
\text { - A necessidade constante de avaliação dos } \\
\text { profissionais e dos trabalhos realizados por eles. }\end{array}$ \\
\hline
\end{tabular}

A aproximação dos profissionais junto à população foi facilitada pelas estratégias de divulgação do programa, pela instalação de escritórios nos centros das áreas urbanas e pelo custo do projeto ser compatível com a renda da população.

Os projetos são realizados de forma simples e didática e discutidos com o profissional até que sejam contempladas todas as necessidades dos moradores. Existe também a preocupação por parte dos arquitetos em proporem intervenções que não anulem a relação dos moradores com a habitação e que respeitem as novas dinâmicas familiares. Esse posicionamento do profissional reforça a aproximação com a população ao levar em consideração os aspectos individuais de cada projeto realizado.

A ampla escala de atuação é o resultado da seriedade dos profissionais e da premissa do programa e do reconhecimento que conquistaram ao longo dos anos de trabalho. A hipótese levantada no início do capítulo é ratificada ao demonstramos que a facilidade de acesso contribui para se ganhar escala de atuação. Por outro lado, esta ampla escala também se deve pela obrigatoriedade da contratação dos profissionais do programa instaurada por meio de resolução expedida pelo Instituto Nacional de Habitação, no ano de 2009.

No próximo capítulo, a partir das análises do Programa Tá Bonito e do Programa Arquitetos da Comunidade, apontaremos os elementos a serem considerados para a elaboração de um programa municipal de assistência técnica de melhorias habitacionais direcionado à população de baixa renda. 


\section{Elementos para uma proposta de assistência técnica}

No presente capítulo, apresentaremos os elementos que consideramos importantes para uma proposta de assistência técnica com base nas experiências de Diadema e de Cuba. Não é nossa intenção fazer uma comparação direta entre os dois programas, pois cada um deles foi concebido dentro de realidades políticas, econômicas e socioculturais diferenciadas.

Vale ressaltar que há pontos divergentes entre os dois programas. O Programa Tá Bonito se propôs a oferecer os serviços de assistência técnica para a melhoria das moradias consolidadas no núcleo Vila Olinda juntamente com o subsidio para a compra do material de construção e para o pagamento da mão de obra. 0 Programa Arquitetos da Comunidade foi concebido e ainda é ofertado como um serviço de assistência técnica continuado, acessivel a toda população e desvinculado de programas de subsídio da compra de materiais ou do pagamento da mão de obra. Ambos partem da oferta de serviço de assistência técnica individualizada com 0 intuito de melhorar as condições de habitabilidade do espaço construído da moradia.

Isto posto e sem querer esgotar o debate acerca do tema, será a partir das dificuldades, dos aprendizados e das conquistas alcançadas por estes programas que destacamos os elementos a nosso ver fundamentais para a construção de um programa de assistência técnica de melhorias habitacionais para a população de baixa renda, quais sejam: 1) as estratégias de divulgação dos programas e o acesso aos serviços; 2) a aproximação do arquiteto com a população; 3) a elaboração dos projetos personalizados e 4) os resultados e as limitações. 


\subsection{As estratégias de divulgação dos programas e 0 acesso aos serviços}

A Tabela 3 ilustra as estratégias de divulgação e a forma de acesso aos serviços de ambos programas e pontua as dificuldades encontradas e as conquistas contempladas.

Tabela 3. Estratégias de divulgação e forma de acesso aos serviços.

\begin{tabular}{|c|c|c|}
\hline \multicolumn{3}{|c|}{ Estratégias de divulgação e forma de acesso aos serviços } \\
\hline & $\begin{array}{l}\text { Programa Tá Bonito - } \\
\text { Diadema/SP }\end{array}$ & $\begin{array}{l}\text { Programa Arquitetos da Comunidade - } \\
\text { Holguín/Cuba }\end{array}$ \\
\hline Dificuldades & $\begin{array}{l}\text { - Ainda que haja uma disponibilidade dos } \\
\text { técnicos em assessorar a elaboração do } \\
\text { projeto da população participante ou } \\
\text { não do programa, como não existe uma } \\
\text { estrutura exclusiva para a assistência } \\
\text { técnica, podemos dizer que o acesso } \\
\text { também é restrito e fracamente } \\
\text { institucionalizado. } \\
\text { - A falta de recursos financeiros e } \\
\text { humanos que impediu a continuidade } \\
\text { do programa. }\end{array}$ & $\begin{array}{l}\text { - Quantidade de profissionais que pode se tornar } \\
\text { incompatível com a demanda, uma vez que a } \\
\text { demanda pelos pareceres técnicos, } \\
\text { especialmente os cartorários, ocupam boa parte } \\
\text { do tempo dos profissionais comprometendo o } \\
\text { desempenho dos mesmos. }\end{array}$ \\
\hline Conquistas & $\begin{array}{l}\text { - O empenho dos técnicos em elaborar a } \\
\text { segunda fase do programa que } \\
\text { contemplou a melhoria interna das } \\
\text { unidades habitacionais. } \\
\text { - Construção do programa junto com os } \\
\text { moradores. }\end{array}$ & $\begin{array}{l}\text { - Divulgaçãa dos serviços nos meios de } \\
\text { comunição de massa (TV); } \\
\text { - Atendimento à população nas cidades com mais } \\
\text { de } 10 \text { mil moradores na área urbana; } \\
\text { - Sistematização do atendimento; } \\
\text { - Instalação de escritórios na área central; } \\
\text { - Uniformização dos serviços prestados; } \\
\text { - Custo dos serviços acessíveis à população } \\
\text { - Inniversalização do acesso); } \\
\text { - Instalação de escritórios acessíveis à população; } \\
\text { - Atendimento em curto espaço de tempo. }\end{array}$ \\
\hline
\end{tabular}

Os principais elementos que se podem apreender dos dois programas para uma proposta de assistência técnica em relação à divulgação e formas de acesso aos serviços são:

- A disponibilidade e a garantia de recursos financeiros e humanos é premissa para que um programa de assistência técnica seja de fato implementado. Independente do programa ser pago ou ser gratuito. 
- A divulgação em si não é suficiente para ter sucesso, ela precisa ser gestada e implantada para atingir o público-alvo específico do programa e estar nos canais de comunicação, locais e horários mais adequados para tal.

- Para atingir o público-alvo específico do programa é preciso conhecê-lo bem através de pesquisas e/ou dados disponíveis e confiáveis.

- A divulgação não deve ser utilizada apenas como uma ferramenta para divulgar o programa, seu funcionamento e oferecer canais de contato, mas também como um meio para que a população tome conhecimento da capacidade técnica que os profissionais, arquitetos e engenheiros possuem.

- A descentralização dos atendimentos com a implantação de escritórios em áreas acessíveis ao público-alvo do programa é uma ação que deve ser incorporada para garantir a proximidade com a população, como foi demonstrado na experiência trazida pelos Arquitetos da Comunidade para tornar-se uma referência à população.

- Os arquitetos e engenheiros devem trabalhar exclusivamente para a oferta de assistência técnica à população. Todavia, a experiência de Cuba nos traz um ponto de atenção. A sobrecarga de trabalhos cartorários imposta aos profissionais pode contribuir para desviá-los do foco do programa no sentido de terem tempo hábil suficiente para a aplicação da metodologia de projeto. Logo, deve-se respeitar uma quantidade de projetos máxima que os profissionais podem assumir para não comprometer a qualidade do serviço.

- $\quad 0$ atendimento deve ser realizado dentro do menor tempo possível para que 0 acesso ao programa torne-se efetivo.

- $\quad$ Sistematização dos atendimentos para que o programa consiga ganhar escala de atuação compatível com a demanda a ser atendida. Em Cuba, todos os grupos dos Arquitetos da Comunidade respeitam o mesmo protocolo de atendimento à população.

\subsection{Aproximação dos profissionais junto à população}


A Tabela 4 ilustra as estratégias de aproximação do profissional junto à população de ambos programas e pontua as dificuldades encontradas e as conquistas contempladas.

Tabela 4. Aproximação do profissional junto à população.

\begin{tabular}{|c|c|c|}
\hline \multicolumn{3}{|c|}{ Aproximação do profissional junto à população } \\
\hline & $\begin{array}{l}\text { Programa Tá Bonito - } \\
\text { Diadema/SP }\end{array}$ & $\begin{array}{c}\text { Programa Arquitetos da Comunidade - } \\
\text { Holguín/Cuba }\end{array}$ \\
\hline Dificuldades & $\begin{array}{l}\text { - Visão do arquiteto culturalmente } \\
\text { associada ao profissional que atende as } \\
\text { classes de maior renda; } \\
\text { - Desconhecimento do papel do arquiteto } \\
\text { dentro da prática da autoconstrução. } \\
\text { - Visão do arquiteto como um agente } \\
\text { fiscal que irá impor os parâmetros e as } \\
\text { regras de ocupação do solo; e } \\
\text { - Falta de credibilidade inicial no } \\
\text { programa. }\end{array}$ & $\begin{array}{l}\text { - Há ainda clientes que iniciam as obras antes da } \\
\text { contratação do profissional }\end{array}$ \\
\hline Conquistas & $\begin{array}{l}\text { - A permanência dos técnicos do } \\
\text { programa diariamente durante o período } \\
\text { de obras permitiu com que fossem } \\
\text { estabelecidos vínculos importantes com } \\
\text { a população, moradores e mão de obra. }\end{array}$ & $\begin{array}{l}\text { - Visão cultural positiva do profissional construída } \\
\text { historicamente com o Programa; } \\
\text { - A garantia da continuidade da prestação do } \\
\text { serviço. } \\
\text { - O conhecimento por parte dos profissionais } \\
\text { (arquitetos e engenheiros) dos aspectos } \\
\text { construtivos e jurídicos que envolvem a moradia. } \\
\text { - Elaboração de projeto participativo onde se } \\
\text { avaliam a história da moradia e a interação dos } \\
\text { moradores com a casa. } \\
\text { - Formas simples e didáticas de apresentação do } \\
\text { projeto. As dificuldades nas leituras das plantas } \\
\text { são ultrapassadas pela disponibilidade dos } \\
\text { profissionais em sanarem as dúvidas junto aos } \\
\text { moradores. } \\
\text { - Descrição específica das responsabilidades, } \\
\text { benefícios e penalidades a que os profissionais } \\
\text { estão sujeitos, bem como sua efetiva aplicação. } \\
\text { - Os mesmos profissionais são responsáveis pelo } \\
\text { atendimento de regiões determinadas do } \\
\text { município. } \\
\text { - Os vínculos criados com os profissionais chegam } \\
\text { ao ponto dos moradores fidelizarem-se com } \\
\text { determinados profissionais. }\end{array}$ \\
\hline
\end{tabular}


Os principais elementos que se podem apreender dos dois programas para uma proposta de assistência técnica em relação a estratégias de aproximação do profissional junto à população são:

- A garantia da continuidade do serviço de assistência técnica é um elemento importante, conforme demonstrou o Programa Arquitetos da Comunidade que nos seus 20 anos de existência construíram uma relação de confiança com a população. Ao passo que no contexto brasileiro, a descrença dos moradores é uma barreira importante a ser ultrapassada;

- Os profissionais que fazem parte de um programa de assistência técnica devem conhecer de forma aprofundada os aspectos construtivos e jurídicos que envolvem a moradia para que se tornem referência à população;

- $\quad$ Os engenheiros e arquitetos devem ter um perfil compatível com o público-alvo que será atendido pelos programas de assistência técnica para que dessa forma possam se estabelecer vínculos com os moradores.

- Dividir o município em regiões de atendimento para que os profissionais designados para atuarem nessas áreas sempre sejam os mesmos, uma vez que a aproximação e a confiança com a população tem um forte componente de fator pessoal, pois é através do profissional que o morador tem acesso e contato com o programa.

- Tornar o morador apto a participar na identificação dos problemas da moradia e corresponsáveis pelas soluções apontadas em projeto. Essa ferramenta é de extrema importância para que não haja recusa da população aos profissionais e às soluções técnicas necessárias para sanar patologias construtivas e pontos de insalubridade que colocam em risco a segurança e a saúde da população. Ainda que esse ponto seja referente à elaboração do projeto, ele reflete de forma direta na aproximação com o profissional.

- Investir em formas simples e didáticas de comunicar o projeto para que os moradores se apropriem daquilo que está sendo proposto e, a partir disso, possa ser estabelecido de fato um diálogo entre os moradores e os profissionais;

- A existência de um código que regulamente a conduta e a responsabilidade dos profissionais agrega seriedade ao programa de assistência técnica, método e gera confiança na população; 


\subsection{Elaboração dos projetos personalizados}

A Tabela 5 ilustra o método de elaboração do projeto de ambos programas e pontua as dificuldades encontradas e as conquistas contempladas.

Tabela 5. Elaboração dos projetos personalizados.

\begin{tabular}{|c|c|c|}
\hline \multicolumn{3}{|c|}{ Elaboração dos projetos personalizados } \\
\hline & $\begin{array}{l}\text { Programa Tá Bonito - } \\
\text { Diadema/SP }\end{array}$ & $\begin{array}{c}\text { Programa Arquitetos da Comunidade - } \\
\text { Holguín/Cuba }\end{array}$ \\
\hline Dificuldades & $\begin{array}{l}\text { - Ao se utilizar apenas da linguagem } \\
\text { tradicional da arquitetura (plantas, } \\
\text { cortes e fachadas), compromete-se a } \\
\text { apropriação do projeto pelo morador } \\
\text { dificultando a aceitação das propostas } \\
\text { de intervenção e a negociação daquilo } \\
\text { que é prioridade diante dos recursos } \\
\text { disponíveis. } \\
\text { - A ocupação da área total do lote pelas } \\
\text { construções, originada no momento da } \\
\text { urbanização do núcleo, dificulta sanar } \\
\text { problemas de umidade e de infiltração } \\
\text { e compromete a ventilação e a } \\
\text { iluminação dos cômodos. } \\
\text { - Dificuldade em se formular medidas } \\
\text { para correção das patologias } \\
\text { construtivas dentro do contexto da } \\
\text { autoconstrução que perpassa a } \\
\text { unidade isolada. }\end{array}$ & - Não ter a certeza do contato com a mão de obra. \\
\hline Conquistas & $\begin{array}{l}\text { - Pela dificuldade apresentada pelos } \\
\text { moradores em compreender as } \\
\text { propostas elaboradas pelos } \\
\text { profissionais, a equipe técnica do } \\
\text { programa propôs outra forma de } \\
\text { apresentação em outra comunidade, } \\
\text { como a maquete; } \\
\text { - Contato permanente com a mão de } \\
\text { obra para sanar possíveis dúvidas } \\
\text { durante a realização das obras }\end{array}$ & $\begin{array}{l}\text { - Após a formação do profissional, é necessário } \\
\text { fazer uma espécie de residência por dois anos } \\
\text { para se especializar nas funções que o cargo de } \\
\text { Especialista em Conservação e Reabilitação } \\
\text { exige. } \\
\text { - Cinco profissionais experientes selecionam os } \\
\text { arquitetos e engenheiros que assumirão os cargos } \\
\text { de Especialistas em Conservação e Reabilitação. } \\
\text { - Reuniões semanais entre os profissionais do } \\
\text { grupo para discussão dos trabalhos em } \\
\text { desenvolvimento. } \\
\text { - A metodologia Livingston adotada pressupõe uma } \\
\text { formação mais variada e interdisciplinar } \\
\text { (psicologia, sociologia, direito e técnicas de } \\
\text { trabalho simples) com reflexo direto sobre o } \\
\text { profissional que atuará no Programa. } \\
\text { - Formação continuada dos profissionais. }\end{array}$ \\
\hline
\end{tabular}


Os principais elementos que se podem apreender dos dois programas em relação ao método de elaboração do projeto são:

- Criar uma metodologia de atendimento e de elaboração de projeto que possa ser aplicada por todos os profissionais para permitir ganho de escala de atuação;

- Criar uma metodologia de projeto que leve em consideração propostas com o mínimo de intervenções possíveis uma vez que os recursos materiais e humanos para a construção da casa pelo morador foram empregados ao longo de anos;

- Identificar junto com os moradores as reais necessidades expressas por eles para que o projeto corresponda aos seus anseios. Por isso o estabelecimento efetivo de diálogo no sentido do morador apreender de fato o que o profissional expressa e vice-versa;

- A formação dos arquitetos e engenheiros deve perpassar os aspectos construtivos a serem enfrentados e, dessa forma, ser compatível com as questões sociais e jurídicas que a autoconstrução impõe;

- Necessidade de vivência prática dos profissionais recém-formados supervisionada por profissionais mais experientes para que aqueles se tornem aptos a responderem de forma adequada às especificidades intrínsecas da assistência técnica de melhorias habitacionais.

- $\quad$ Ter um contato próximo com a mão de obra durante a execução das obras uma vez que se trata de intervenções em construções existentes e que muitas soluções construtivas devem ser apontadas nesse momento. A experiência de Diadema demonstrou a importância de a obra ser acompanhada de perto pelos técnicos.

\subsection{Resultados e limitações}

A Tabela 6 a seguir aponta os resultados e limitações de ambos programas e pontua as dificuldades encontradas e as conquistas contempladas. 
Tabela 6. Resultados e limitações dos programas.

\begin{tabular}{|c|c|c|}
\hline \multicolumn{3}{|c|}{ Resultados e limitações dos programas } \\
\hline & $\begin{array}{l}\text { Programa Tá Bonito - } \\
\text { Diadema/SP }\end{array}$ & $\begin{array}{c}\text { Programa Arquitetos da Comunidade - } \\
\text { Holguín/Cuba }\end{array}$ \\
\hline Dificuldades & $\begin{array}{l}\text { - A falta de pós-acompanhamento das } \\
\text { moradias atendidas pelo programa faz } \\
\text { com que patologias decorrentes dos } \\
\text { desgastes naturais dos materiais } \\
\text { empregados recriem ambientes } \\
\text { insalubres e, no limite, mostrem a } \\
\text { ineficácia do programa e consequente } \\
\text { descrédito da população por esse tipo } \\
\text { de programa e profissional; } \\
\text { - A mão de obra desqualificada, as } \\
\text { intervenções em construções precárias, } \\
\text { a topografia acidentada dos lotes, as } \\
\text { vielas estreitas e a necessidade de } \\
\text { remoção das familias para a realização } \\
\text { das obras causaram atraso no } \\
\text { cronograma físico e o aumento do custo } \\
\text { previsto no cronograma financeiro; } \\
\text { - O período de um ano decorrido entre o } \\
\text { início do programa dentro da } \\
\text { comunidade e a liberação do início das } \\
\text { obras, bem como a falta de } \\
\text { compreensão por parte dos moradores } \\
\text { da importância de se cumprir o contrato } \\
\text { assinado junto à CEF, fez com que } \\
\text { alguns serviços previstos em projeto } \\
\text { fossem realizados pelos moradores sem } \\
\text { qualquer acompanhamento; } \\
\text { - Dificuldade da associação de } \\
\text { moradores em gerenciar os recursos, a } \\
\text { contratação da mão de obra e a compra } \\
\text { do material de construção; } \\
\text { - Pela observação empírica, algumas } \\
\text { moradias sofreram interferências após a } \\
\text { finalização do programa, o que sugere } \\
\text { que a assistência técnica não precisa } \\
\text { necessariamente estar vinculada ao } \\
\text { financiamento ou ao subsídio da } \\
\text { compra do material de construção. Esta } \\
\text { observação é passível de maiores } \\
\text { estudos e análises; }\end{array}$ & $\begin{array}{l}\text { - Os especialistas assumiram o papel de agentes } \\
\text { fiscalizadores do governo o que pode limitar os } \\
\text { espaços para as constantes inovações do } \\
\text { trabalho; } \\
\text { - Assumiram funções cartorárias ao serem } \\
\text { designados em lei como responsáveis pelas } \\
\text { correções dos títulos de propriedade dos imóveis; } \\
\text { - Faltam escritórios independentes em dez dos } 14 \\
\text { municípios que compõem a província de Holguín; } \\
\text { - } 40 \% \text { dos profissionais (arquitetos e engenheiros) } \\
\text { não utilizam o AutoCad ou qualquer outro } \\
\text { software como ferramenta de desenho. }\end{array}$ \\
\hline Conquistas & $\begin{array}{l}\text { - Capacidade dos técnicos em lidar com } \\
\text { as dificuldades durante o } \\
\text { desenvolvimento do programa ao rever } \\
\text { os projetos, os cronogramas físicos e } \\
\text { financeiros e a logística das obras; }\end{array}$ & $\begin{array}{l}\text { - Reconheceu-se a importância dos profissionais } \\
\text { (arquitetos e engenheiros) na contribuição das } \\
\text { soluções dos problemas envolvendo a moradia; } \\
\text { - Até o ano de } 2012 \text { já tinham sido realizados mais } \\
\text { de } 185 \text { mil atendimentos na província de Holguín; }\end{array}$ \\
\hline
\end{tabular}




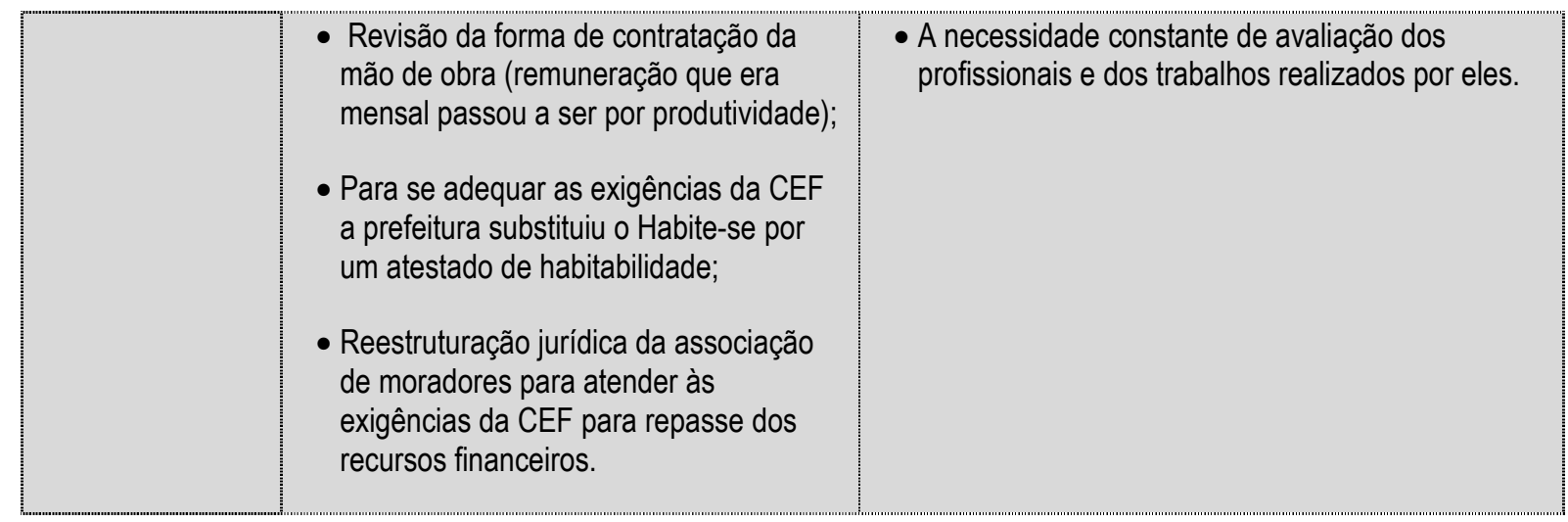

Os principais elementos que se podem apreender dos dois programas para alcançar resultados satisfatórios e dessa forma garantir a replicabilidade do programa são:

- A assistência técnica deve ocorrer de forma continuada e de maneira independente dos recursos para compra de material de construção. Em Diadema, alguns moradores atendidos pelo Programa Tá Bonito demonstraram capacidade de disponibilizar recursos para empreender sozinhos intervenções construtivas nas suas moradias, bem como no caso cubano;

- $\quad$ município deve pensar em formas de substituição da responsabilidade técnica dos profissionais pelas construções. Pode-se pensar, ao seguir o exemplo de Diadema, em um atestado de habitabilidade expedido pelo município;

- $\quad$ Necessidade de ter uma avaliação constante do programa e dos profissionais que 0 compõem por meio dos trabalhos realizados. Assim é possível a identificação de falhas e pontos que merecem atenção na busca por melhores soluções.

\subsection{Conclusões}

As duas experiências abordadas com maior profundidade neste trabalho, apesar de representarem uma amostra restrita, são do nosso ponto de vista suficientemente representativas dos variados desafios e aprendizados de programas de assistência técnica de melhoria habitacional para a população de baixa renda. E suficientes para que a partir delas sejam depreendidos elementos para elaboração ou melhorias desses programas. 
Os elementos ora apresentados circunscritos às estratégias de divulgação dos programas, ao acesso aos serviços, à aproximação do arquiteto com a população e à elaboração dos projetos personalizados, embora individualmente relevantes sob nossa perspectiva, foram propostos dentro de uma visão orgânica de conjunto necessária para o seu sucesso. E essa organicidade somente é passível de ocorrer quando garantidos adequadamente os preceitos de institucionalização, continuidade, método e avaliação contínua do programa.

Embora o Programa Arquitetos da Comunidade tenha as suas dificuldades e pontos de atenção, o que é natural em qualquer tipo de empreendimento, público ou privado, ele pode ser considerado um sucesso especialmente por possuir esses preceitos. Adicionalmente, do ponto de vista do método, a metodologia Livingston tem se mostrado bem adequada para o programa de acordo com os próprios profissionais e com os resultados alcançados de diálogo, identificação e atendimento das necessidades da população. 


\section{Considerações Finais}

No Brasil, a contratação dos serviços de arquitetura como uma das soluções para evitar os problemas decorrentes da falta de planejamento e da construção desassistidos é algo distante da população, principalmente da mais pobre. Direcionar esforços para disponibilizar a assistência técnica continuada para a promoção de melhorias nas moradias consolidadas autoproduzidas pela população de baixa renda é demonstrar respeito pelos investimentos realizados por milhares de famílias que, com recursos próprios e ao longo de décadas, solucionaram sozinhas sua necessidade de morar; à margem das políticas habitacionais centradas na produção de novas unidades.

A Lei Federal $n^{\circ}$ 11.888, sancionada em 2008, fruto de discussões iniciadas desde 2002 , assegurou em seu texto o direito às famílias com renda mensal de até três salários mínimos a assistência técnica gratuita para a construção ou a melhoria da edificação existente, a ser oferecida 
pelos municípios de forma continuada. Embora muitos municípios tenham aprovado leis próprias seguindo a lei federal, em quase nada avançaram na efetivação desse direito. Tanto isso é verdade que, em 2012, durante o $8^{\circ}$ Seminário Nacional de Assistência Técnica, ainda eram discutidas maneiras de viabilizar a efetivação da assistência técnica pelos municípios brasileiros, mesmo que 0 Plano Nacional de Habitação, como instrumento de planejamento com horizonte em 2023, tenha a assistência técnica como uma das suas cinco linhas programáticas de ação.

Em Diadema, a disponibilização do acesso ao serviço de assistência técnica apenas durante a realização da segunda fase do Programa Tá Bonito, no núcleo Vila Olinda, apesar de contribuir para a melhoria dos aspectos físicos das unidades naquele momento, não garantiu que novas intervenções realizadas pelos moradores não reproduzissem as mesmas deficiências e as precariedades que motivaram a criação do programa, ou seja, não logrou alterar a cultura dos moradores nesse sentido.

A proposta do programa era de fato parte de uma política habitacional elaborada pelo município, desde o início da década de 1980, em torno da urbanização e da regularização fundiária das favelas. Entretanto, programas dessa natureza, que se objetivam a influenciar e a sustentar a mudança de cultura e de valores sobre a intervenção dos próprios moradores prescindem de planejamento e de ações explícitas em sua concepção e desenho.

Em Cuba, a assistência técnica foi instituída como um programa de alcance nacional frente a uma situação generalizada de deterioração do estoque habitacional do país, agravada pela escassez dos materiais de construção durante a crise econômica, iniciada com a queda do bloco socialista no início da década de 1990, e pela consequente redução da participação do Estado na provisão de habitação.

Os Arquitetos da Comunidade, em um primeiro momento, atuaram de maneira independente da política habitacional e, posteriormente, após a conquista do reconhecimento pela população, passou a integrar o sistema nacional de habitação como uma ação para a melhoria da condição de habitabilidade das moradias.

A resposta a essa necessidade não ocorreu apenas dentro dos princípios da boa técnica. $A$ metodologia de projeto adotada pelos Arquitetos da Comunidade considera o projeto personalizado não apenas uma ferramenta de desenho, mas um meio de aproximação dos profissionais com a população ao estabelecer de fato um diálogo com os moradores e, assim, apreender as suas reais necessidades. Dessa forma, o programa consegue ser, verdadeiramente, uma resposta à urgência do problema habitacional ao conseguir atingir uma ampla escala de atuação em todo o território cubano. 
A presente pesquisa visou analisar as duas propostas de assistência técnica sem a intenção de traçar uma comparação direta entre os programas, pois reconhecemos que foram construídos dentro de contextos políticos, econômicos e socioculturais diferenciados. Mas de discutir as maneiras como a assistência técnica foi oferecida e implantada com o objetivo de oferecer a melhoria das condições de habitabilidade do espaço da moradia, dirigindo o nosso olhar às estratégias de divulgação dos programas, ao acesso aos serviços, à aproximação do arquiteto com a população e à elaboração dos projetos personalizados. A partir disso, apontamos os elementos que consideramos fundamentais para a construção de um programa de assistência técnica direcionado às melhorias habitacionais, conscientes de que a discussão acerca do tema não se esgota neste trabalho, mas que necessariamente deve passar pelas questões da institucionalização, continuidade, método e avaliação contínua do programa. 


\section{Referências}

ABIKO, A. K.; ALMEIDA, M. A. P. Urbanização de favelas em Diadema, no período de 1983 a 1988. São Paulo: Editora da Universidade de São Paulo, 1994. Disponível em: $<$ <ttp://www.pcc.usp.br/files/text/publications/BT_00128.pdf>. Acesso em: 26 fev. 2014

ABRAMO, Pedro. Quatro notas preliminares sobre a teoria econômica da favela: localização residencial e mercado imobiliário. IX ENCONTRO NACIONAL DA ANPUR. Anais... Rio de Janeiro, v. 3, 2001.

AGUIAR E SOUZA, Leandro. A participação do futuro morador em projetos habitacionais de baixa renda: estudos de caso., Dissertação em arquitetura e urbanismo, Escola de arquitetura da Universidade Federal de Minas Gerais, 2007.

ARRUDA, A. M. V.; CUNHA, E. M. P.; MEDEIROS, Y. (org.). Experiências em habitação de interesse social no Brasil. Brasília: Ministério das Cidades/Secretaria Nacional de Habitação, 2007. Disponível em:<http://www.capacidades.gov.br/biblioteca/detalhar/id/80/titulo/AssistenciaTecnica\%2CumDireitode 
TodosConstruindoumaPoliticaNacionalExperienciasemHabitacaodeInteresseSocialnoBrasil>. Acesso em: 26 fev. 2014.

BONDUKI, Nabil; ROLNIK, Raquel. Formação da periferia da Grande São Paulo: elementos para análise. In: MARICATO, Ermínia (org.). A produção capitalista da casa (e da cidade) no Brasil industrial. Editora Alfa-Omega 2. ed. São Paulo, 1982, p. 117-154.

BONDUKI, Nabil. Origens da habitação social no Brasil. Arquitetura moderna, Lei do Inquilinato e difusão da casa própria. 3. ed. São Paulo: Estação Liberdade/ FAPESP, 2002.

BONDUKI, Nabil. Habitação e autogestão: construindo territórios de utopia.; FASE, Rio de Janeiro, 1992.

Habitar São Paulo: reflexões sobre a gestão urbana. São Paulo: Estação Liberdade, 2000.

Habitação Popular: Contribuição para o Estudo da Evolução Urbana de São Paulo. In: VALLADARES, Lícia do Prado (org.). Repensando a habitação no Brasil. Rio de Janeiro: Zahar Editores, 1983, p. 135-168.

BOUILLON, César Patrício. Un espacio para el desarrollo: los mercados de vivienda en América Latina y el Caribe. Banco Interamericano de Desenvolvimento (BID), 2012.

FERREIRA, João Sette Whitaker. Perspectivas e desafios para o jovem arquiteto no Brasil. Qual o papel da profissão? Arquitextos, São Paulo, ano 12, n. 133.07, Vitruvius, jul. 2011. Disponível em: <http://www.vitruvius.com.br/revistas/read/arquitextos/12.133/3950 >. Acesso em: 26 fev. 2014.

CANO, Wilson; Brandão, Carlos A. (coords.), A região metropolitana de Campinas: urbanização, economia, finanças e meio ambiente - campinas, SP: editora da Unicamp, 2002.

COELHO, M. C. S. Espaço de Direitos É mais que Direito a Espaço. O Processo de Urbanização de Favelas em Diadema (1983 - 2008). 2008. 179 f. Dissertação (Mestrado em Serviço Social) - Pontifícia Universidade Católica de São Paulo, São Paulo, 2008.

CONSELHO DE ARQUITETURA E URBANISMO DO BRASIL. Brasil já têm 106 mil arquitetos e urbanistas. Disponível em <http://www.caubr.gov.br/?p=14019>. Acesso em: 26 fev. 2014. 
DAVIS, Mike. Planeta favela, tradução de beatriz Medina - São Paulo: Boitempo, 2006, 272 p.

DENALDI, Rosana. Políticas de Urbanização de Favelas: evolução e impasses. 2003. 242 f. Tese (Doutorado em Arquitetura e Urbanismo) - Faculdade de Arquitetura e Urbanismo, Universidade de São Paulo, São Paulo, 2003. Disponível em:

<http://www.pucsp.br/ecopolitica/downloads/tes_2003_Politicas_urbanizacao_impasses.pdf>. Acesso em: 26 fev. 2014.

FERNANDES, Florestan. Da guerrilha ao socialismo: a revolução Cubana., $3^{0}$ ed. São Paulo, Expressão Popular, 2012, 336 p.

FUPAM/LABHAB/FAUUSP. Parâmetros Técnicos para a urbanização de favelas. São Paulo, 1999. Relatório Final.

GUIMARÃES, V. M. B. C. Q. A Linguagem da Imagem Digital: o desenho da casa na autoconstrução. 2005. s/n. Dissertação (Mestrado em Multimeios) - Instituto de Artes, Universidade Estadual de Campinas, Campinas, 2005. Disponível em: <http://www.bibliotecadigital.unicamp.br>. Acesso em: 26 fev. 2014.

IAB. Manual para implantação de assistência técnica pública e gratuita a famílias de baixa renda para projeto e construção de Habitação de Interesse Social. 2010

INSTITUTO BRASILEIRO DE GEOGRAFIA E ESTATÍSTICA. Censo Demográfico 2010: Características da população e dos domicílios - Resultados do Universo. Disponível em: <http://biblioteca.ibge.gov.br/visualizacao/periodicos/93/cd_2010_caracteristicas_populacao_domicilios. pdf>. Acesso em: 26 fev. 2014.

Censo Demográfico 2010: Aglomerados subnormais - Informações territoriais. Disponível em: <ftp://ftp.ibge.gov.br/Censos/Censo_Demografico_2010/Aglomerados_subnormais/Aglomerados_subno rmais_informacoes_territoriais/aglomerados_subnormais_informacoes_territoriais.pdf>. Acesso em: 26 fev. 2014.

INSTITUTO DIADEMA DE ESTUDOS MUNICIPAIS (IDEM). Diadema e a cidade informal.; $1^{0}$ edição, IDEM, São Paulo, 2011.

LAGO, Luciana Correa. Autogestão habitacional no Brasil: utopias e contradições., Rio de Janeiro : Letra Capital : Observatório das Metrópoles, 2012. 256p.

LEMOS, Carlos A C.; SAMPAIO, Maria Ruth. A; Casa proletária em São Paulo. São Paulo: FAUUSP, 1993. 
LIMA, M. H. B. Em busca da casa própria: autoconstrução na periferia do Rio de Janeiro. In: VALLADARES, Lícia do Prado (org.). Habitação em questão. Rio de Janeiro: Zahar Editores, 1980, p. 69-91.

LIVINGSTON, Rodolfo. Arquitectos de familia: el método: arquitectos de la comunidad., 1 ed. Buenos Aires, Nobuko, 2006, 320 p.

LIVINGSTON, Rodolfo. Cirugia de casas., Libreria tecnica CP67 S.A., $9^{\circ}$ edição, 1998.

MAUTNER, Yvonne, A periferia como fronteira de expansão do capital. In: DEÁK, C.; SCHIFFER, S. R. O processo de urbanização no Brasil. São Paulo: Editora da Universidade de São Paulo, 2010.

MARAGNO, G. V. Questões sobre a qualificação e o ensino de arquitetura e urbanismo no Brasil. In: ENCONTRO NACIONAL SOBRE ENSINO DE ARQUITETURA E URBANISMO, 31., p. 46 - 66, 2012, São Paulo. Anais eletrônicos... São Paulo: ABEA, 2012. Sessão temática 1. Disponível em: <http://www.abea-arq.org.br/wp-content/uploads/2013/03/artigo_maragno-pgn1.pdf>. Acesso em: 26 fev. 2014.

MARICATO, Ermínia. Autoconstrução, a arquitetura possível. In: MARICATO, Ermínia (org.). A produção capitalista da casa (e da cidade) no Brasil industrial. Editora Alfa-Omega, 2. ed. São Paulo, 1982, p.71-93.

Habitação e Cidade. São Paulo: Atual, 1997.

MILLÁN, Keila González; COTO, Ana Marta Amaro. Experiencias del Arquitecto de la Comunidad en Cuba. Material apresentado no Primeiro Encontro Latino Americano Arquitetos da Comunidade. Montevideu, 2010.

MORAIS, Fernando. A ilha: um repórter no país de Fidel Castro. São Paulo, Compania das Letras, 2001.

NASCIMENTO, Denise Morado; TOSTES, Simone Parrela. Programa Minha Casa Minha Vida: a (mesma) política habitacional no Brasil. Arquitextos, São Paulo, ano 12, n. 133.03, Vitruvius, jun. 2011 Disponível em: <http://www.vitruvius.com.br/revistas/read/arquitextos/12.133/3936>. Acesso em: 26 fev. 2014.

OLIVEIRA, Francisco de. Crítica à razão dualista - o ornitorrinco. Boitempo editorial, São Paulo, 2003, $150 \mathrm{p}$. 
PREFEITURA MUNICIPAL DE DIADEMA. Relatório do programa Tá Bonito., Secretaria Municipal P.M. Diadema, 2008.

PREFEITURA MUNICIPAL DE TABOÃO DA SERRA. Relatório do PSH de 2011. Taboão da Serra, 11 de julho de 2012.

YAMAGUTI, Alexander Syoei. Pré-fabricação por ajuda mútua: conhecer, ensinar e aprender - Sao Paulo, 2006. Dissertação (Mestrado - Área de concentração: Habitat) - FAUUSP, 112 P.

\section{Legislação}

BAURU. Lei $n^{0} 5.815$ de de 26 de novembro de 2009. Institui a assistência técnica pública e gratuita para o projeto, acompanhamento e execução da construção de habitação de interesse social, assegurada às famílias com renda mensal de até 03 (três) salários mínimos. Disponível em: $<$ <ttp://www.bauru.sp.gov.br/arquivos/sist_juridico/documentos/leis/lei5815.pdf> . Acesso em: 26 fev. 2014.

BELO HORIZONTE. Lei $\mathrm{n}^{0}$ 8.758, de 16 de Janeiro de 2004. Institui o serviço de arquitetura e engenharia públicas, altera a lei $n^{0} 8574 / 03$, que dispõe sobre facilitação de acesso, a espaço público, de pessoa portadora de deficiência ou com mobilidade reduzida, e dá outras providências. Disponível em: <https://www.leismunicipais.com.br >. Acesso em: 26 fev. 2014.

BRASIL. Lei $n^{0} 11.888$, de 24 de dezembro de 2008. Assegura às famílias de baixa renda assistência técnica pública e gratuita para o projeto e a construção de habitação de interesse social e altera a Lei no 11.124, de 16 de junho de 2005. Disponível em <http://www.planalto.gov.br/ccivil_03/_Ato20072010/2008/Lei/L11888.htm>. Acesso em: 26 fev. 2014.

CAMPINAS. Lei $n^{0} 7.653$, de 22 de outubro de 1993. Autoriza a prefeitura municipal de campinas a fornecer projetos e especificações técnicas para a construção de habitações econômicas com área de até 70,00 (setenta) metros quadrados, autoriza a concessão de dispensa do pagamento do imposto sobre serviços de qualquer natureza e dá outras providências. Disponível em: <https://www.leismunicipais.com.br >. Acesso em: 26 fev. 2014.

CAMPINAS. Lei n 13.886 de 19 de julho de 2010. Institui o Programa Municipal de Assistência Técnica Gratuita para projeto, construção, reforma e regularização predial de habitação de interesse social no Município, voltado e assegurado às famílias com renda mensal de até três salários mínimos, nos termos da Lei Federal $n^{0}$ 11.888, de 24 de dezembro de 2008. Disponível em <http://leismunicipa.is/ohcba>. Acesso em: 26 fev. 2014. 
CUBA. Lei $\mathrm{n}^{0} 65$ de 23 de dezembro de 1988. Lei geral de Habitação. Disponível em: <http://www.gacetaoficial.cu/html/leygeneralvivienda.html>. Acesso em: 26 fev. 2014.

CUBA. Resolução No. 50 de 23 fevereiro de 2009. Disponível em: <http://faolex.fao.org/docs/pdf/cub91244.pdf>. Acesso em 26 fev. 2014

RIBEIRÃO PRETO, Lei $n^{0}$ 12.215/2009. Institui o programa municipal de assistência técnica ã habitação de interesse social no município de Ribeirão Preto. Disponível em: <http://leismunicipa.is/snboj>. Acesso em: 26 fev. 2014.

SÃO PAULO. Lei n ${ }^{0}$ 13.433, de 27 de setembro de 2002. Dispõe sobre o serviço de assessoria técnica em habitação de interesse social, autoriza o executivo a celebrar convênios e termos de parceria e dá outras providências. Disponível em: <https://www.leismunicipais.com.br >. Acesso em: 26 fev. 2014.

TABOÃO DA SERRA. Lei no 1846/2009, assegura o direito das famílias de baixa renda à assistência jurídica, técnica gratuita para o projeto e a construção de moradia, bem como proporciona a oportunidade de regularização das edificações residenciais econômicas construídas sem a respectiva autorização como parte integrante do direito social a moradia previsto no art. $6^{\circ}$ da Constituição Federal, e institui o Programa Municipal de Assistência Técnica à Moradia Econômica (ATME). Disponível em: <http://leismunicipa.is/pbtdi>. Acesso em: 26 fev. 2014.

\section{Sites consultados}

ASSOCIAÇÃO BRASILEIRA DE CIMENTO PORTLAND (ABCP). Quem Somos; site da ABCP, sem data. Disponível em: <http://www.abcp.org.br/conteudo/quem_somos/apresentacao/associacaobrasileira-de-cimento-portland> Acesso em: 15 out. 2013.

ASSOCIAÇÃO BRASILEIRA DE DESENVOLVIMENTO INDUSTRIAL - ABDI. Estudo Panorama Setorial de Construção Civil. Brasília, 2009. Disponível em: <http://www.abdi.com.br/Estudo/Panorama\%20Setorial\%20de\%20Constru\%C3\%A7\%C3\%A30\%20Civil .pdf> Acesso em: 26 fev. 2014.

CAIXA ECONÔMICA FEDERAL. Prestação de Serviços de Assistência Técnica Para Habitação de Interesse Social, Banco Caixa Econômica Federal, sem data. Disponível em: <http://www1.caixa.gov.br/gov/gov_social/municipal/assistencia_tecnica/produtos/repasses/habitacao_d e_interesse_social/presta_serv_assist_tecnica_habit_interesse_social/saiba_mais.asp> Acesso em: 26 fev. 2014.

CASTRO RUZ, Fidel. La Historia me absolverá., Disponível em: <http://www.granma.cubaweb.cu/martimoncada/jm01.html> Acesso em: 26 fev. 2014. 
COMISSÃO ECONÔMICA PARA AMÉRICA LATINA E CARIBE (CEPAL), NAÇÕES UNIDAS PROGRAMA DAS NAÇÕES UNIDAS PARA O DESENVOLVIMENTO (PNUD), IINSTITUTO NACIONAL DE INVESTIGAÇÕES ECONÔMICAS (INIE). Política Social y Reformas Estructurales: Cuba a principios del siglo XXI. Organização das Nações Unidas, 2004. Disponível em: $<$ http://www.eclac.org/cgi-

bin/getProd.asp?xml=/publicaciones/xml/3/15003/P15003.xml\&xsl=/mexico/tpl/p9f.xsl\&base=/mexico/tpl Itop-bottom.xsl> Acesso em: 26 fev. 2014.

CONSELHO DE ARQUITETURA E URBANISMO (CAU). Tabela de honorários de serviços de arquitetura e Urbanismo do Brasil. Brasilia/DF, 16 de agosto de 2013. Disponível em: $<$ http://www.caubr.gov.br/wp-content/uploads/2013/11/2013.08.16-CEAUeCBA-Tab-Remun-Proj-ArqEdif.pdf> Acesso em: 26 fev. 2014.

COYULA, M. El trinquenio amargo y la ciudad distópica: autopsia de una utopía. Conferência no Instituto Superior de Arte (La Habana), ciclo La política cultural de la Revolución: memoria y reflexión, organizado pelo Centro Teórico-Cultural Criterios, 19 de março de 2007. Disponível em: $<$ http://laventana.casa.cult.cu/modules.php?name=News\&file=article\&sid=3666> Acesso em: 26 fev. 2014.

DOS SANTOS, Andrea; Santos, Alexandre Pereira; PAIXÃO, Diogo; DE CARVALHO, Guilherme Carpinteiro; SALAZAR, Jeferson; STROHER, Laisa Eleonora Marostica; DE SOUZA, maria Tereza Peres. Relato de encaminhamentos e propostas do $8^{\circ}$ Seminário Nacional de Assistência Técnica, 13 a 14 de Novembro de 2012 - Curitiba/PR. Disponível em: <http://www.fna.org.br/site/uploads/noticias/arquivos/8-Seminario-Nacional-de-AT_relato-FINAL.pdf> Acesso em: 26 fev. 2014.

GARCIA, Dora Nisenbaun (coord.). Con tus proprias manos: Como construir y mejorar tu vivienda primera parte., MICONS, ministério de la construcción, Cuba, 2011. Disponivel em: $<$ <ttp/micons.netcons.com.cu/tabloides/doc_download/14-tabloide-con-tus-proprias-manos-primeraparte-> Acesso em: 26 fev. 2014.

IAB. Manual para implantação da assitência tecnica pública e gartuíta a familias de baixa renda paa projeto e construção de habitação de interesse social. Instituto de Arquitetos do Brasil. Disponível em: $<$ http://issuu.com/iab-rs/docs/iab_manual_at>. Acesso em: 26 fev. 2014.

KANE WU, Cintia; NAKAKURA, Elza. ABCP - Mãos à obra. Sem data. Disponível em: <http://www.clubedareforma.com.br/maos-a-obra> Acesso em 15 out. 2013.

LEITE, Fabiane. Laje é área de lazer em São Paulo. Jornal Folha de São Paulo, Caderno Cotidiano, 27 de janeiro de 2002. Disponível em: <http://www1.folha.uol.com.br/folha/cotidiano/ult95u44774.shtml> Acesso em: 26 fev. 2014. 
MAGALHÃES, Sergio. Rio: favela ou bairro., Dialogos Cariocas, 2009. Universidade Federal do Rio de Janeiro. Disponivel em <http://dialogoscariocas.com.br/wpcontent/uploads/2014/02/sergiomagalhaes_030720091.pdf>. Acesso em 26 fev. 2014.

MESA-LAGO, Carmelo. Problemas sociales y económicos en Cuba durante la crisis y la recuperación. Revista da CEPAL, agosto de 2005. Disponível em: <http://www.mesalago.com/source/G2282eMesaLago\%5B1\%5D\%20Cuba\%20CEPAL.pdf> Acesso em: 26 fev. 2014.

MISLEH, Soraya. Assistência técnica para habitação de interesse social como política pública, Sindicato dos engenheiros no Estado de São Paulo. <http://www.seesp.org.br/site/edicoes-anterioresdo-je/23-je-350/172-assistencia-tecnica-para-habitacao-de-interesse-social-como-politica-publica.html> Acesso em: 26 fev. 2014.

O ESTADO. Prefeitura de Fortaleza realizará 40 mil melhorias habitacionais até 2016. Fortaleza, 17 de maio de 2013. Disponível em: <http://www.oestadoce.com.br/noticia/prefeitura-de-fortaleza-realizara40-mil-melhorias-habitacionais-ate-2016> Acesso em: 26 fev. 2014.

OFICINA NACIONAL DE ESTADÍSTICA. Censo de População e Habitação 2012. Disponível em: <http://www.one.cu/informenacional2012.htm>. Acesso em 26 fev. 2014.

OFICINA NACIONAL DE ESTADÍSTICA. Los Censos de Población y Viviendas en Cuba: 1907 - 1953. Disponível em: <http://www.one.cu/loscensos.htm>. Acesso em 26 fev. 2014.

PORTAL G1. Uma em cada três lesões na coluna vem de queda de laje; veja o que fazer. Portal G1, 19 de dezembro de 2011. Disponível em <http://g1.globo.com/bemestar/noticia/2011/12/uma-em-cadatres-lesoes-na-coluna-vem-de-queda-de-laje-veja-o-que-fazer.html> Acesso em: 26 fev. 2014.

PREFEITURA MUNICIPAL DE FORTALEZA. Programa Casa Bela entregará 73 cheques para reformas em casas, Fortaleza, 28 de fevereiro de 2012. Disponível em: $<$ http://portalantigo.fortaleza.ce.gov.br/index.php?option=com_content\&task=view\&id=17850\&ltemid=23 9> Acesso em: 15 out. 2013.

PREFEITURA MUNICIPAL DE FORTALEZA. Programas. Disponível em: <http://www.fortaleza.ce.gov.br/habitafor/programas> Acesso em: 15 out. 2013.

RABINOVICH, Adriana. Los intereses sectoriales de la vivienda social en Cuba, EchoGéo (online), 12 de 2010, 31 de maio de 2010, Disponível em: <http://echogeo.revues.org/11695>; DOI: 10.4000/echogeo.11695. Acesso em: 30 jan. 2014. 
RAVSBERG, Fernando. Vivienda em Cuba: un problema aún sin solución, BBC Mundo, la Habana, 3 de outubro de 2013.2 Disponivel em: $<$ http://www.bbc.co.uk/mundo/noticias/2013/10/130917_cuba_mujeres_albergues_crisis_viviendas_Ips. shtml> Acesso em 26 fev. 2014.

ROLNIK, Raquel; Nakano, Anderson Kazuo. As armadilhas do pacote habitacional. Revista Le Monde Diplomatique Brasil, 5 de março de 2013. Disponível em: <http://www.diplomatique.org.br/artigo.php?id=461>. Acesso em: 26 fev. 2014.

SECRETARIA NACIONAL DE HABITAÇÃO. Plano Nacional de Habitação. Versão para debates. Brasilia: Ministério das Cidades/ Secretaria Nacional de Habitação, Primeira impressão: Maio de 2010, $212 p$.

SILVA, Vania. Programas integrados agregam aprimoramento profissional para jovens arquitetos e melhor qualidade de vida para população de favelas do Rio de Janeiro, Revista eletrônica AU, edição 110 de maio de 2003. Disponível em: <http://au.pini.com.br/arquitetura-urbanismo/110/pioneirismocidadania-e-trabalho-23528-1.aspx>. Acesso em 26 fev. 2014.

\section{Materiais Especiais}

FAMÍlIA Braz Dois Tempos. Direção: Dorrit Harazim e Arthur Fontes. São Paulo: Videofilmes e Conspiração, 2010. 